\title{
Fear, Anger, and Credit. On Bank Robberies and Loan Conditions
}

\author{
Paola Morales-Acevedo \\ Central Bank of Colombia \\ Carrera 7 No 14-78, Bogota, Colombia \\ Telephone: +573125253425 \\ E-mail: amoralac@banrep.gov.co

\begin{abstract}
Steven Ongena *
University of Zurich, Swiss Finance Institute, KU Leuven and CEPR
\end{abstract} \\ Plattenstrasse 14, 8032 Zurich, Switzerland \\ Telephone: +41 44 6342951, Fax: +41 446344903 \\ E-mail: steven.ongena@bf.uzh.ch
}

June 9, 2019

\begin{abstract}
* Corresponding author. We thank two anonymous referees, David Chambers, Hans Degryse, Olivier De Jonghe, Vasso Ioannidou, Chris James, Lena Jaroszek, Asim I. Khwaja, Yaping Mao, David Martínez Miera, Raghavendra Rau, Kasper Roszbach, Tuomas Takalo, Peter van der Velden, Erik von Schedvin, Wesley W. Wilson (the Editor), Frans Willem Winkel, and seminar participants at Aalto University (Helsinki), Bilkent University (Ankara), London School of Economics, the universities of Cambridge, Geneva, and Zurich, the Riksbank (Stockholm), and Tilburg University, and participants at the $8^{\text {th }}$ Swiss Winter Conference on Financial Intermediation (Lenzerheide), the Wolpertinger Conference (Verona), and the Shandong University Workshop on Informal Finance Risk (Jinan) for helpful comments, and Dave Brooks (the English Language-Coaching Service) for excellent editorial assistance. We acknowledge financial support from Carefin - Bocconi Centre for Applied Research in Finance and Ongena acknowledges financial support from ERC ADG 2016 - GA 740272 lending. We thank the Central Bank of Colombia for providing one of the authors of this paper access to its Commercial Credit Register.
\end{abstract}


Fear, Anger, and Credit.

On Bank Robberies and Loan Conditions

\begin{abstract}
We study the impact of emotions on real-world decisions made by loan officers by analyzing the loan conditions of loans granted immediately after a bank branch robbery. We find significant differences between the conditions of loans granted after a robbery and changes in loan conditions that occur contemporaneously at unaffected branches. In general, loan officers seem to adopt so-called avoidance behavior. In accordance with the literature on posttraumatic stress, their avoidance behavior is halved within two weeks following the robbery and the effect further varies depending on the presence, or absence, of a firearm during the robbery.
\end{abstract}

JEL Codes: G02, G2.

Keywords: behavioral finance, bank robberies, transactional versus relationship lending. 


\section{I.INTRODUCTION}

During the last few decades, there has been a growing interest in understanding the role emotions play in judgment and choice. Research in the cognitive sciences has found that both immediate emotions (experienced at the time of the decision and that might arise from factors unrelated to it) and expected emotions (predictions of the emotional responses to decisions' outcomes) may play an important role in the decision-making process (Loewenstein (2000), Lerner and Keltner (2001), Lowenstein and Lerner (2003)).

Recent research in financial economics has naturally focused on the central role emotions play in traders' decision-making (Saunders (1993), Lo and Repin (2002), Lo, Repin and Steenbarger (2005), Fenton-O'Creevy, Soane, Nicholson and Willman (2011)). Learning strategies for emotion regulation seem to have important consequences for traders' behavior and performance. According to Fenton-O'Creevy, Soane, Nicholson and Willman (2011), for example, high-performance traders are more inclined to regulate their emotions and to cope with negative feelings. By contrast, low-performance traders engage in avoidant behaviors or invest substantial cognitive effort in modulating their emotional responses. ${ }^{1}$

Besides traders, there is an important class of individuals that take important financial decisions on a daily basis, yet that have hardly been analyzed; that is to say, loan officers

\footnotetext{
${ }^{1}$ Italian investors are found to have responded emotionally to the most recent financial crisis (Guiso, Sapienza and Zingales (2014)), Investors respond emotionally to terrorist attacks (Agarwal, Ghosh and Zhao (2019), Wang and Young (2019)), mutual fund managers change their professional risk taking behavior when their personal wealth is affected by a decline in house prices (Pool, Stoffman, Yonker and Zhang (2019)), and financial professionals are found to be substantially more fearful and risk averse when primed with a financial bust (Cohn, Engelmann, Fehr and Maréchal (2015)).
} 
at bank branches. These individuals are, around the world, in charge of key decisions related to the process of granting loans. They evaluate, authorize, recommend approval, and/or define the loan terms of new loans. They base their decisions on a set of rules imposed by the bank, as well as on their own perception of the loan applicant. This perception, however, is influenced by loan officers' experience, education, ethnicity, social background, and to a large extent the emotions experienced at the time they analyze the loan application.

Although there has been a lot of research on the determinants of lenders' judgment, discretion, and choices, including tastes, ${ }^{2,3}$ the role of loan officers' emotions has been somewhat ignored. ${ }^{4}$ This may be attributed to a lack of data and, in particular, the difficulty of finding the right setting that allows researchers to isolate the effect of emotions on credit outcomes, in particular on loan terms.

In this paper, we study the impact of emotions on real-world decisions made by loan officers. We do so by analyzing the conditions of loans granted immediately after an

${ }^{2}$ Textbooks have long prescribed the inputs into the decision-making process (e.g., the 5Cs-Character, Capacity, Capital, Collateral, and Conditions), the decision process, and the required characteristics of loan officers. Recent empirical work has documented the determinants of these officers' discretion (Cerqueiro, Degryse and Ongena (2011), Degryse, Liberti, Mosk and Ongena (2011), Puri, Rocholl and Steffen (2011)), the impact of delegation (Liberti (2004)) and pay (Brown, Westerfeld, Schaller and Heusler (2012), Agarwal and Ben-David (2017)), their willingness to game the expert software (Berg, Puri and Rocholl (2013)), and their discrimination (taste-based à la Becker (1957)) on the basis of the gender or race of potential borrowers (Ravina (2009), Bellucci, Borisov and Zazzaro (2010), Hertz (2011), Beck, Behr and Guettler (2012), Ongena and Popov (2016)).

${ }^{3}$ Giné, Garcia and Gómez-González (2017) performed an audit study in Colombia, in which individuals as potential borrowers were trained to behave according to varying characteristics on: i) The degree of financial knowledge; ii) the dress code; and iii) the knowledge of a better offer at another financial institution. They find that the information provided by the loan officers and their final offer depends on the characteristics analyzed.

${ }^{4}$ Anecdotal evidence and interviews with loan officers indicate that "gut feeling" may play an important (though not always the over-riding) role in credit decisions (e.g., the structured interviews with fourteen loan officers at one bank in Israel in Lipshitz and Shulimovitz (2007) and the critical incident analysis involving 88 loan officers at four Swedish banksTrönnberg and Hemlin (2014)). 
exogenous event that directly and affected the emotions of the loan officers. The exogenous events we focus on are bank branch robberies. Such robberies provide "reasonable quasinatural experiments", 5 with a number of unique and salient characteristics (Diagram 1 provides an illustrative road map to the discussion that now follows).

Robberies are not caused by loan officers` recent successes or failures (as in some of the aforementioned empirical literature investigating traders` behavior), making the change in emotions incidental (and not integral to the decision-making process), ${ }^{6}$ and robberies are rare and notoriously difficult to predict with respect to the exact branch and time at which the action will take place. We show that also in our setting robberies are rare and close to impossible to predict where and when they will take place.

Other works analyze loan approvals and outcomes around emotional events that are more aggregate and/or anticipated. In a paper closest to ours, Cortés, Duchin and Sosyura (2016), for example, use daily fluctuations in local sunshine as an instrument for sentiment to study its effect on credit approvals by lower-level financial officers. They find that positive sentiment is associated with higher credit approvals, and that negative sentiment has the opposite effect of a larger magnitude. ${ }^{7}$

\footnotetext{
${ }^{5}$ However, given that we investigate non-randomized quasi-natural experiments, and despite our best efforts, we acknowledge that some possibility remains that the 'treatment' is confounded with unmeasured variables, which in the end may leave our findings open to other interpretations than those hypothesized.

${ }^{6}$ Incidental emotions from non-task relevant effects may (via mood contagion) be erroneously experienced as task relevant and may have adverse effects on decision making (emotions as bias). It is this emotion contagion effect (which is harmful to a loan officer`s judgement) which we study. In contrast, integral emotions which are caused by the task and decision itself may provide useful experience-informed cues about what to pay attention to and how to respond (emotions as information) (e.g., Fenton-O'Creevy, Soane, Nicholson and Willman (2011)).

${ }^{7}$ Agarwal, Duchin, Evanoff and Sosyura (2013) analyze the impact on loan approval of nationwide events such as the Super Bowl and the American Idol contest, and days around major holidays. Relatedly, Campbell, Loumioti and Wittenberg Moerman (2018) analyze loan quality when loan officers are busy or before weekends and around national holidays, Demiroglu, Ozbas, Silva and Ulu (2017) analyze performance of
} 
Bank robberies also take place "on the job"- that is to say, in the place and during the times loan officers work, ${ }^{8}$ and are likely to be charged with emotions (like fear and/or anger) of negative valence (Frijda (1986), p. 207), because these events are almost always characterized by the actual use or (severe) threat of violence.

Given all this loan officers often experience several posttraumatic stress symptoms after a robbery: increased awareness of surroundings, sleep disturbance, nightmares, difficulty concentrating, avoidance, anxiety, irritability, and outbursts of anger are among the symptoms encountered (Leymann (1988), Kamphuis and Emmelkamp (1998), MillerBurke, Attridge and Fass (1999)). ${ }^{9}$ The symptoms are commonly experienced immediately after the robbery; they are, however, found to diminish rapidly within the first week following the incident and only few if any of the symptoms remain six months later (Leymann (1988)).${ }^{10}$ Consequently, the impact of bank robberies on loan terms can be measured instantly after the event and will reduce over time.

\footnotetext{
loans originated during Ramadan in Turkey, while Baele, Farooq and Ongena (2014) analyze loan performance itself during Ramadan in Pakistan.

${ }^{8}$ Though comparable in emotional impact, personal events such as death or illness of family members, the birth of children, or marital conflicts for example are more difficult to interpret with regard to their workplace impact, may potentially not be independent of employee performance, and/or are in most countries impossible to record due to privacy laws. Infra we analyze the impact of the local team winning soccer games in the national cup tournament.

${ }^{9}$ Those who continue to experience problems may be diagnosed with post-traumatic stress disorder (PTSD), which in the US is estimated to affect, at some point during their lives, up to 6 percent of men and 14 percent of women (Kessler, Sonnega, Bromet, Hughes and Nelson (1996), Yehuda (2002)) and 30 percent of male Vietnam veterans (Schlenger et al. (1992)). In Colombia, 20 percent of children in war-affected areas (PérezOlmos, Fernández-Piñeres and Rodado-Fuentes (2005)) and between 25 and 50 percent of internally displaced adults (Richards, Ospina, Barrera and Marmar (2011), Cabas-Hoyos et al. (2016)) suffer from PTSD (the recent National Health Survey indicates that 10 percent of adults exhibit symptoms of psychological trauma, including post-traumatic stress disorder, anxiety disorders, and major depression; see Bons (2015)). PTSD is linked to depression, generalized anxiety disorder, panic disorder, substance abuse, and health conditions including hypertension, asthma, and chronic pain syndrome; it may lead to intimate partner violence and child abuse (Cesur and Sabia (2015)) and severe economic consequences related to psychiatric, psychosocial, and occupational impairments (Brunello et al. (2001)).

${ }^{10}$ Interestingly, robbery witnesses remember for a long time and with great accuracy many details of the robbery in question (e.g., action, weapon, clothing), but in contrast to other stressful events there may not be
} 
Moreover, the severity of the consequences experienced by loan officers is influenced by the intensity of the bank robbery. Miller-Burke, Attridge and Fass (1999) for example found that the use of weapons by the assailants is associated with the loan officers experiencing more symptoms of post-traumatic stress - that is to say, higher perceived stress, worse physical health, and worse work productivity after the robbery. We therefore expect to find a stronger effect on the loan conditions granted by branches that have experienced a more violent robbery than on those granted by branches that have not.

In sum, robberies yield almost perfectly exogenous but temporary shocks of varying strength to the emotional state of mind of the loan officers affected by the robbery, which allows us to identify how incidental emotions determine loan conditions (which are the outcomes in our context of the decision making process).

To accomplish this analysis we therefore combine two unique datasets. We first access unique data collected by the Policía Nacional de Colombia, the Colombian National Police, which contains detailed information on 389 bank robberies that took place in Colombia between 1998 and 2011. In particular we will employ the address of the branch robbed, the exact date of the robbery, the amount stolen, the weapon used, and the type of robbery. Matched with the robbery data, we use information on commercial loans reported by financial institutions to the Superintendencia Financiera de Colombia, the regulator of Colombia's financial system. Detailed information on the loan conditions - that is to say,

a significant relationship between the degree of emotion involved and the number of details remembered (Christianson and Hübinette (1993)). 
maturity, collateral, interest rate, loan amount, loan rating, and the date of origination of the loan is provided for all the commercial loans granted between 1998 and 2010.

We employ a difference in differences approach to measure what effect a bank robbery has on loan conditions. The treatment group for each event corresponds to the loans granted locally by the bank whose branch was robbed, and the control group corresponds to the loans that were granted by all banks in the rest of the country (in robustness, in the rest of the region). In order to rule out structural changes in the process of granting loans (due to, for example, monetary policy changes or internal organizational changes), we define an event window for each bank robbery that retains only those loans granted up to 90 days before and up to 90 days after the bank robbery. In addition, we include a set of branchevent fixed effects in order to account for any observable and unobservable branch-specific heterogeneity across time, and-in augmented specifications-business-year: quarter fixed effects to account for observable and unobservable time-varying heterogeneity in the volume and quality of business credit demand.

We find significant differences in the conditions of the loans granted after a robbery suggesting that loan officers do change their decision-making following this type of event. ${ }^{11}$ In general loan officers seem to adopt so-called avoidance behavior: they decrease at once the likelihood of entering into contact with the client by lengthening the maturity

\footnotetext{
${ }^{11}$ This change fits with the recently framed decision-from-experience paradigm (de Palma et al. (2014)) in which the consequences of decisions are learned from experience and decision-makers under-respond to rare events (see also, e.g., Abdellaoui, L'Haridon and Paraschiv (2011)); in extremis rare events are even completely neglected as "Black Swans" (Taleb (2007)). This is the opposite pattern than that of the more established decision-from-description paradigm, aka prospect theory (e.g., Tversky and Kahneman (1992)), in which decision-makers tend to overestimate the probability of rare events and make overly cautious, suboptimal decisions as a result. However it is unclear if in the decision-from-experience paradigm intensifying elements (such as firearms) and swift reversals (of a few weeks), which are a key to our findings, can be easily accommodated.
} 
of the loan contract and by demanding more collateral, thereby reducing the probability of loan non-performance (and dealings with the client) prior to maturity. These effects are also economically meaningful. Maturity increases by 3.3 months, for an average (median) maturity of 8.7 (3) months, ${ }^{12}$ while the likelihood that collateral is pledged increases by 3.4 percentage points (pp), relative to a mean likelihood equal to 18.4 percent, and collateralization (i.e., collateral over loan amount) increases by $3.9 \mathrm{pp}$, relative to an average collateralization of 15.4 percent.

However, as the symptoms experienced by the loan officer are likely to wear off quickly (or so the literature on post-traumatic stress suggest), the effect on these loan conditions should commensurately dissipate. And indeed we find that the avoidance behavior that manifests itself in maturity, collateral, and collateralization is halved within the two weeks following the robbery.

Further consistent with avoidance behavior is our finding that loan officers end up granting loans with ceteris paribus slightly softer loan conditions, possibly reflecting a reduced willingness to spend face-to-face negotiation time with applicants (Mosk (2013)). Loans at once carry a somewhat lower interest rate and a higher loan amount: the interest rate drops by 30 basis points (bps), relative to a mean interest rate of 17.2 percent, and the loan amount increases by 34 million Colombian pesos (COP), relative to a mean loan amount of COP 928 million. Finally, we find that loans granted after a robbery are more

\footnotetext{
12 Put differently, if firms have at all times one loan outstanding and loans are immediately renewed at maturity (and assuming 25 working days in a month), the probability of a visit by a customer on a given day would go down from 0.45 (1.3) percent to 0.33 (0.66) percent, a reduction of 27 (50) percent in visitation frequency and hence the number of customers visiting the branch per day.
} 
likely to be non-performing, indicating the relevance of our findings concerning loan officers`emotions for optimal credit allocation by banks in the economy.

But the effect further varies depending on the presence of a firearm during the robbery. In robberies where the perpetrator carries a firearm, loan officers subsequently adopt stricter avoidance behavior, with longer maturity and higher collateral requirements, and the correspondent lower loan rates and higher loan amounts. But where a robbery occurs without a firearm being involved, collateral requirements and loan amount initially drop while loan rates increase.

That the results differ according to the presence of a firearm during the robbery is interesting and fully consistent with the idea that different emotions may be triggered depending on the circumstances of the event. When the robber has a firearm loan officers are likely to feel overpowered and threatened, i.e., subject to an aversive stimulus, so fear and afterward depressed resignation will most likely be the emotions that prevail, with socalled avoidance behavior as outcome. On the other hand, loan officers that are present at robberies without any firearms involved are possibly less terrified during the ordeal, and angry afterward. They could feel anger because their space and security has been violated, yet they were not able, or courageous enough, to prevent the incident occurring, with socalled approach behavior as outcome. ${ }^{13}$

We enrich the interpretation of our findings further by analyzing in detail robbers revisitations of branches and the differentiated impact by bank type, number of employees

\footnotetext{
${ }^{13}$ In line with this reasoning Lerner and Keltner (2001) find that fear and anger have opposite effects on risk perception for example. Whereas fearful individuals made pessimistic risk-avoidance choices, angry individuals made tough, risk-seeking choices.
} 
at the branch, loan amount, firm size, and bank-firm relationship length. ${ }^{14}$ We also explore potential alternative explanations, including the accumulation of work, changes in bank policies and customer reactions, but find these to be rather inconsistent with our estimates. Finally, we study an alternative setting, i.e., the wins by the local soccer team in the national cup.

Given the uniqueness of robberies as quasi-natural experiments, our paper helps to distinguish between competing theories in the literature with regard to the effect of lifethreatening events on human behavior - a literature that began with the seminal paper by Malmendier and Nagel (2011), who show that early-life financial experiences may be linked to more conservative later-life investing behavior, potentially suggesting an increase in risk aversion. Bernile, Bhagwat and Rau (2017) for example document a non-monotonic relation between the intensity of CEOs' early-life exposure to fatal disasters and corporate risk-taking (see also, e.g., Eckel, El-Gamal and Wilson (2009), Voors et al. (2012), Kim and Lee (2014), Cameron and Shah (2015), Oswald, Proto and Sgroi (2015), Dessaint and Matray (2017)).

In essence, these papers study the potentially lasting effects of life-threatening events for economic risk preferences that are central to general managerial decision-making_-but for which causality is often difficult to establish due to mobility and selective migration as

\footnotetext{
${ }^{14}$ Based on one of the authors` own experiences working in the financial sector in Colombia, and as is the case in many other countries around the world (e.g., Germany in Lehmann and Neuberger (2001) and Puri, Rocholl and Steffen (2011), Argentina in Degryse, Liberti, Mosk and Ongena (2011), Albania in Beck, Behr and Guettler (2012), Switzerland in Brown, Westerfeld, Schaller and Heusler (2012)), we know that loan officers in branches can and will exert discretion in setting loan terms, especially when located at smaller branches (in the provinces) of domestic banks and for smaller loans to smaller firms that are relationship customers (e.g., Berger and Udell (2002), Berger and Udell (2006)).
} 
natural confounds, ${ }^{15}$ and for which findings seem contradictory. In contrast, we can assuredly identify the immediate impact on the specific terms of loans (that can be reasonably tied to certain elements of behavior) granted by loan officers as part of their daily work following bank branch robberies that threaten their normal work environment and routines. ${ }^{16}$

The rest of the paper proceeds as follows: Section II describes our identification strategy. Section III introduces the econometric methodology used in our analysis. Section IV describes the data and provides descriptive statistics. Section V contains the empirical results, including tests for robustness and an assessment of potential alternative explanations. Conclusions follow in Section VI.

\section{II.IDENTIFICATION STRATEGY}

\section{Robbery of a Bank Branch}

A robbery itself may be the outcome of an economic decision-making process followed by the robber(s) (Ozenne (1974)), and bank branch robberies provide interesting quasinatural experiments. Bank branch robberies are actually quite rare in many countries. ${ }^{17}$

\footnotetext{
${ }^{15}$ Much less affected by such confounds is a study by Callen, Isaqzadeh, Long and Sprenger (2014), who documents a permanent preference for certainty among respondents that were primed to recall exposure to violence in Afghanistan.

${ }^{16}$ Most of the evidence on the role played by emotions in decision-making is collected in experimental settings or from surveys. One recent notable exception is Danziger, Lev and Avnaim-Pesso (2011). They show that taking their food break, and consequently recuperating from possible mental depletion, led eight Israeli judges that were followed throughout 1,112 parole cases over a ten-month period to rule more favorably; favorable rulings dropped from 65 to almost zero percent in the run-up to one of the judges' two daily food breaks, jumping back up to 65 percent immediately after a break.

${ }^{17}$ Robberies in general and violent crimes with potentially similar emotional impacts are of course still very common in many countries. For example in the US in 2015 there were 125,000 robberies involving a firearm, households faced a 11.1 percent annual probability of being affected by a property crime, and persons aged
} 
Many bank branches will not experience a robbery for a long time, if ever. During our eight-year sample period - that is to say, 2003:01-2011:12, for which we obtain data from the National Police of Colombia, 835 bank robberies took place. During this time period there were around 4,250 bank branches in Colombia resulting in an average yearly hazard rate at the branch level of 2.2 percent. Compared to other crimes, bank robberies are fairly uncommon (Lamm Weisel (2007)) and always create something of a local "event". ${ }^{18}$ If anything, robberies have become even rarer over time (O'Flaherty (2009)) in many countries, including in Colombia. The hazard rate at the branch level in our sample drops from 4.2 percent in 2003 to 1.7 percent in 2011.

Robberies are notoriously difficult to predict with respect to where (branch), ${ }^{19}$ and especially precisely when (day and time) they will take place. Surprise is an essential ingredient in any robbery, otherwise the police could just sit, wait, and arrest the perpetrator(s).

12 or older faced a 1.86 percent annual probability of being the victim of a violent crime (e.g., Truman and Morgan (2015)). In this respect Colombia seems a fairly representative country. For example, in terms of the number of robberies recorded by the police per 100,000 inhabitants, Colombia ranked $48^{\text {th }}$ among 107 countries (high to low) (Source: NationMaster).

${ }^{18}$ In 2011 on average only 0.3 bank robberies took place per day, coincident with 1 kidnapping, 18 sex crimes, 35 store robberies, 40 homicides, 60 car or motorcycle thefts, 103 cases of domestic violence, and 166 larceny events, for example. Source: Ministerio de Defensa Nacional. República de Colombia.

${ }^{19}$ This is also the case in our sample. We try to predict robberies taking place with a variety of linear and logit models that include the one year (quarter) lag of the first and second moments of all available loan conditions in municipal banks' branches and that in linear specifications also include a comprehensive set of municipal fixed effects to capture local economic and social conditions (see Appendix Tables A.1 to A.3). For the panel 2002-10, for example, 501 of the 594 robberies observed were not predicted within the year that they took place (the within-quarter results are even "worse"). In our most demanding falsification tests, infra we use branch-year combinations that were false positives. 


\section{a. Location}

While the exact branch and time at which a robbery will take place is difficult to predict, higher unemployment or fewer police officers per capita not surprisingly spur more robberies across US States (Samavati (2006)), as does a branch being located in or close to a low-income area (Hannan (1982)), ${ }^{20}$ that is to say, a branch's proximity to potential offenders is a key factor in helping to predict branch robberies (Baumer and Carrington (1986)). Easy access to a highway or an arterial route (to get away) and distance from a police station (Baumer and Carrington (1986)) may also play a role.

At the branch level there are also certain characteristics that seem to attract robbers. Robbers seem to like multiple entrances to a building, a higher number of tellers, a longer distance between any two tellers, and reduced visibility from within or outside of the bank (Baumer and Carrington (1986)), and seem to dislike security guards located at the door (Hannan (1982)), but do not seem to care much about other commonly used security equipment. To account for these observable, and other unobservable, branch characteristics that may also attract or repel robbers with certain motives (Johnston (1978)), we include branch-event fixed effects.

While in general robberies are difficult to predict in space and time, there is one exception. Branches do get robbed multiple times, often within a short period of time (e.g., Lamm Weisel (2007) for the US), either because the robbers think they have left unfinished business behind them (and there is still money there for the asking), or because the robbery

\footnotetext{
${ }^{20}$ Bank mergers if and when constraining access to credit may result in more crime in a local community, a seminal study by Garmaise and Moskowitz (2005) shows.
} 
was easy to pull off (so why not visit again for a second serving), or because competing robbers copycat. While we have branch-event fixed effects and compare only 90 days before and after (this also removes the possibility that any recurrent robbery takes place), we also - in robustness exercises — remove those branches that are robbed multiple times.

\section{b. Time}

Yet even despite this observed multiplicity, robberies remain rare - that is to say, even revisitations are not that common and in time are still almost random. In our total sample of robberies for example there are 63 revisitations, with an average time between them of 1.3 years.

Most of the robberies are holdups, ${ }^{21}$ either by lone bandits or teams. Lone bandits that are armed or unarmed often act in an ill-prepared manner and on a whim. In order not to be recognized afterward lone robbers rarely study the branch they rob. Teams are always armed and are typically more prepared, in terms of location, but even then the exact branch they rob and the exact timing of their actions cannot be predicted that well.

In some countries a lot more robberies take place on a Friday as branches sit on payday money (and the opportunist robber may need money for weekend partying) or on other days with extended opening hours (Lamm Weisel (2007)), but that does not seem to be so overwhelmingly the case in Colombia. ${ }^{22}$ There are also more robberies during winter time in countries where scarves and hats are then commonly worn, but again this is not the case

\footnotetext{
${ }^{21}$ Of the 835 robberies in the dataset 474 are bank holdups and 260 teller holdups. There are 38 cases of tunneling, 11 entries outside opening hours, and 7 cases of staff impersonation. A total of 35 cases are classified as "other" or were left unclassified.

22 Of the 835 robberies in the dataset, 105 take place on Monday, 172 on Tuesday, 150 on Wednesday, 163 on Thursday, 192 on Friday, 41 on Saturday, and only 12 take place on Sunday (likely because most if not all bank branches are closed then).
} 
in Colombia as there are no "real" seasons. The aforementioned set of branch-event fixed effects also accounts for observed and unobserved heterogeneity in the calendar timing of the robbery.

\section{The Impact of Robberies}

Robberies are potentially traumatic events. Bank employees (and also customers) may be threatened, injured, taken hostage, or even killed. Miller-Burke, Attridge and Fass (1999) and also Leymann (1988), for example, document that many employees who experienced a robbery in the branch at which they worked suffered negative consequences in a variety of areas affecting both their individual lives and their work for the company. "To varying degrees, this impact included experiencing numerous clinical symptoms of post-traumatic stress, greater perceived stress, worse physical health, impaired productivity at work, less desire to continue working for the current employer, and problems in both work and personal relationships."

The negative impact of the workplace trauma was worse when the robbery was more intense - that is to say, a weapon was used by the robber, there was close proximity to the robber, and the perceived personal threat was high. These effects were not moderated, Miller-Burke, Attridge and Fass (1999) find, by the potentially confounding factors of employee age, gender, and job position, though ex ante employee training can help assuage the emotional effects of victimization (Lamm Weisel (2007)). So these findings suggest 
that reaction to a robbery is not or is only weakly related to (for us unobservable) employee characteristics. $^{23}$

Similarly Kamphuis and Emmelkamp (1998) document that employees who had experienced a robbery evidenced significantly higher psychological distress than their nonvictimized colleagues. Within the group of employees who experienced a robbery, a correspondence was found between the time that had elapsed since the robbery and their current level of psychological distress. These findings suggest significant psychological distress reactions following bank robberies - reactions that decrease over time. We will therefore investigate how the impact of bank robberies on loan terms dissipates over time. Further, Kleim, Ehlers and Glucksman (2007) show that after experiencing a violent traumatic event, such as a robbery or terrorist attack, most people show some symptoms of acute stress disorder, but that only a minority develop persistent symptoms of sufficient severity to warrant a diagnosis of post-traumatic stress disorder (PTSD), which can be predicted to occur after six months from as early as two weeks after the attack (see also Kleim and Ehlers (2009)). Hence we will also study the time trend in the effects following the robbery.

\footnotetext{
${ }^{23}$ We did not find any evidence in the literature that ex post media coverage (see, e.g., Aronson (2012) on media contagion) or the capture of the robbers mitigates trauma (there is no immediate robbery-specific information on media coverage or robbers' arrests available for Colombia in any case). We surmise that coverage or capture may not be moderating factors per se and/or that few robbers are caught immediately. For example, for Italy Mastrobuoni and Rivers (2019) reports that the perpetrators were arrested in only 7 percent of the 4,972 bank robberies recorded between 2005 and 2009; Italy actually witnessed almost 60 percent (sic) of all bank robberies in Europe during that time period. For the US the 2011 FBI Bank Crime Statistics show that only in 20 percent of the 4,534 bank robberies in which money was taken was there eventually full or partial recovery.
} 


\section{Four Testable Hypotheses}

A recent set of experiments by Raghunathan and Tuan Pham (1999) is important for our study. ${ }^{24}$ These start from the observation that many important decisions are made under emotionally taxing conditions. The authors therefore focus on the influence of negative emotions at the time of decision-making. They predict, and experimentally confirm, that in trade-offs between risk and return the negative emotion of anxiety in particular will bias the preferences of the decision-maker toward low-risk, low-return outcomes, even if the decision to be taken is partly or completely unrelated to the anxiety-producing event. Why is that?

First, Raghunathan and Tuan Pham (1999) posit that negative emotions may shape people's decisions by skewing the content of their thoughts. "It is well established that under negative mood people's perceptions, thoughts, and judgments are often distorted toward greater negativity - an effect known as mood congruency." ${ }^{25}$ Second, Raghunathan and Tuan Pham (1999) argue that negative emotions may shape decision-makers' motives and in that way determine decisions. A pervasive motivational shift observed under negative emotions is an intensified concern "for elevating or 'repairing' one's mood". The meaning structure underlying anxiety, they argue, is defined by high uncertainty over an

\footnotetext{
${ }^{24}$ While emotions themselves can be negative or positive, all types of emotions traditionally were considered to have a negative effect on decision quality (or rationality), and were therefore typically described as "disruptive," "illogical," "biased," and "weak" (Putnam and Mumby (1993), p. 36). This is not the perspective of the current literature, however, and the impact of each particular emotion now has to be studied in detail to assess its outcome with regard to the decision that is being taken.

${ }^{25}$ A study by White, McManus and Ehlers (2008) is also relevant in this regard. The authors show that prior to the treatment of a post-traumatic stress disorder, patients overestimated the probability and the cost of all types of traumatic events occurring, relative to non-patients, and that they overestimated the probability and cost of the specific type of traumatic event that they had been traumatized by. These judgment biases were specific to traumatic events and did not generalize to all negative events.
} 
outcome and low control over a situation, which results in an implicit goal of uncertainty reduction for the decision-maker. Finally, Raghunathan and Tuan Pham (1999) argue that negative emotions may alter the process through which people make decisions. Anxiety may interfere with the decision-maker's ability to process information. As a result, anxious individuals are posited to process information less systematically.

So, Raghunathan and Tuan Pham (1999) posits that anxiety is generally experienced in response to situations in which the person is uncertain about an impending outcome of a personally relevant event, especially when the outcome is potentially harmful (e.g., "Is the individual sitting in my office potentially a robber and dangerous?"), and feels unable to alter the course of events (e.g., "I am a loan officer and I have to talk to all loan applicants"), and that anxiety influences decision-makers via the content of any "dark" thoughts they might have ("A robbery can easily be repeated here at this branch now"), motives ("I want to avoid contact with potential robbers"), and the process of decision-making ("It is all futile, I don't care anymore"). Following a robbery we therefore expect loan officers that suffer from anxiety to make loans that require less contact with the applicant, in the future and now. Such anxiety may lead the loan officer to have:

1. Less willingness to roll over a loan in the future, which may lead to granting loans with a longer loan maturity today, in the sense that once the loan is granted the loan officer has the discretion to avoid having contact with the client by choosing not to monitor the loan or to monitor it less; 
2. Less willingness to monitor and deal with a client in the case of non-performance, which may lead to more collateralization. ${ }^{26}$

But loan officers' efforts to avoid contact once the loan has been granted are not limited to lengthening the maturity and asking for more collateral; they may also try to reduce current "face time" with the client during negotiations. Loan officers may try:

3. To avoid long and/or repeated contact with an applicant during negotiations, therefore offering a lower interest rate and a higher loan amount to ensure that the applicant swiftly accepts.

In our context such direct avoidance behavior vis-à-vis applicants will be observationally very distinct from the increasing risk-aversion one could expect to occur in the context of the eventual granting of loans because more risk-averse loan officers should seek shorter loan maturities (e.g., Berger, Espinosa-Vega, Frame and Miller (2005)), less risky collateral (à la Rajan and Winton (1995)), ${ }^{27}$ higher loan rates (incorporating higher risk premia), and lower loan amounts (to reduce exposure). More loss-averse loan officers

\footnotetext{
${ }^{26}$ À la Manove, Padilla and Pagano (2001), who argue that collateral can replace screening and monitoring and allow loan officers to be "lazy". Similarly, Berger and Udell (2006) define "asset-based lending is a transactions lending technology in which financial institutions address the opacity problem by focusing on a subset of the firm's assets, which are pledged as collateral, as the primary source of repayment. [...] The amount of credit extended is linked on a formula basis using hard data to a dynamically-managed estimation of the liquidation value of the assets used as collateral" [our italicizations]. Hence, loan officers will be able to avoid personal contact with borrowers.

${ }^{27}$ As many firms are small and are unlikely to own real estate, reliance on collateralization of movables will be widespread (e.g., Cerqueiro, Ongena and Roszbach (2016)).
} 
similarly will likely seek shorter maturities and lower loan amounts, while more presentbiased loan officers will seek shorter maturities.

But the occurrence and strength of the avoidance behavior may depend on the intensity of the robbery, as different emotions are triggered depending on the levels of potential violence experienced. In robberies in which firearms are used, loan officers face what might be a life-threatening experience; thus, fear could be the most likely emotion to prevail. On the other hand, loan officers that are present during less violent robberies will be less terrified. Instead of fear, the emotion that could be more predominant is anger. They could feel anger because their space and security has been violated and they were not able to prevent the incident. In line with this reasoning, Lerner and Keltner (2001) find that fear and anger have opposite effects on risk perception. Whereas fearful individuals made pessimistic, risk-adverse choices (see also Christelis and Georgarakos (2013) and Cohn, Engelmann, Fehr and Maréchal (2015)), which in our context potentially implies avoiding contact with applicants, angry individuals may act in the opposite way. We will also test this hypothesized difference in behavioral outcomes in response to the presence of a firearm:

4. Whereas in robberies involving firearms avoidance behavior will occur, in potentially less violent robberies such behavior may be mitigated or even cease.

To study the impact of anxiety on real-world decisions made by loan officers, we now test these four hypotheses by investigating the conditions of loans granted in the period 
immediately following the robbery of a bank branch, when branch employees will suffer most from the stress induced by this event.

\section{III.METHODOLOGY}

We employ a difference in differences approach to measure what effect a bank robbery has on loan conditions. The treatment group for each event corresponds to the loans granted locally by the bank that was robbed, and the control group corresponds to the loans that were granted by all banks in the rest of the country. For each bank robbery we define an event window that comprises loans granted up to 90 days before and up to 90 days after the bank robbery.

The econometric model takes the following form:

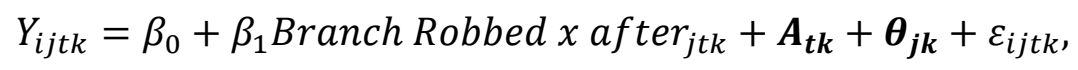

where $i, j, t$, and $k$ index firm, branch, time (in days), and event, respectively.

In Equation (1), $Y_{i j t k}$ represents one of the loan conditions. For each loan condition we estimate a different regression: Maturity is the maturity of the loan in months and Collateral is an indicator variable equals 1 if the loan is collateralized and equals 0 otherwise. Collateralization is the ratio of the collateral and loan amount. Interest Rate is the interest rate of the loan as a percentage and Loan Amount is the amount of the loan in millions of COP. 
The variable Branch Robbed $x$ after $_{j t k}$ is equivalent to the interaction term in a regular difference in differences analysis. It is a dummy variable that equals 1 for the loans that were granted by the robbed branch after a robbery took place. Thus, $\beta_{1}$ is our coefficient of main interest. $\boldsymbol{A}_{\boldsymbol{t} \boldsymbol{k}}$, correspond to after $x$ event fixed effects. They account for temporal differences in loan conditions within the event window. $\boldsymbol{\theta}_{\boldsymbol{j} \boldsymbol{k}}$ corresponds to branch-event fixed effects. They capture any systematic differences across branches (included in the treated or control group) for each event. ${ }^{28}$ Finally, $\varepsilon_{i j t k}$ is the error term, which we cluster at the branch level. ${ }^{29}$

Findings in the psychology literature suggest that loan officers experience several stress symptoms during the first weeks following the robbery that they gradually disappear (but potentially at a decreasing rate) for most loan officers. In view of this fact, we should expect to find a greater effect on loan conditions for the first few weeks after the robbery, and less so for the following weeks. We test if this is the case by interacting the variable Branch Robbed $x$ after $_{j t k}$ with the variable $\ln \left(\right.$ Days After the Robbery $\left.{ }_{t k}\right),{ }^{30}$ which indicates how many days after the robbery the loan was granted.

\footnotetext{
${ }^{28}$ Given these short time windows, which are part of our identification strategy to uncover temporary changes in the behavior of the loan officers and the many small firms observed to borrow infrequently from only one bank, it is not practical to include firm (or firm-day) fixed effects to control for (the robbery-induced changes in) demand. Given that most if not all loan officers will experience the robbery but only few customers will, we surmise that the estimated changes are caused by changes in the behavior of loan officers. We will return to assessing the changes in customer behavior in robustness exercises.

${ }^{29}$ Clustering at the firm level yields similar results.

${ }^{30}$ Using this variable in level (without taking the logarithm) leaves estimates mostly unaffected.
} 


\section{IV.DATA}

We focus on robberies in Colombia, where previous research has already investigated the relationship between conflict and the cultivation of coca (Angrist and Kugler (2008)) and kidnappings (Pshisva and Suarez (2010)), for example.

[Table 1 around here]

For our analysis we use the two datasets we have already briefly introduced. The first comprises information with regard to the bank robberies that took place in Colombia from 2003:1 to 2011:12 and was collected by Policía Nacional de Colombia (the Colombian National Police), and as already indicated includes information on the address of the robbed branch, the date of the robbery, the amount robbed, ${ }^{31}$ the weapon used, and the type of robbery. ${ }^{32}$ The dataset contains 835 bank robberies that took place in one of 170 municipalities and 652 different branches of 28 different banks. The average (median) amount robbed was equivalent to $37,000(4,000)$ US dollars (USD), ${ }^{33}$ which represents less than 1 percent of the total deposits of a bank at the municipal level. About 3 percent of the

\footnotetext{
${ }^{31}$ While this information comes directly from the police and not from press reports we cannot entirely discount the possibility that the amounts robbed were underreported in order to dissuade aspirant robbers. If this underreporting is systematically proportional, however, our variable capturing the amount stolen will still incorporate the same variation.

32 As far as we can tell, information on injuries and casualties associated with each robbery is not systematically recorded and centrally collected and is not publicly available.

${ }^{33}$ In the 1990s (prior to our sample period) robberies of bank branches by organized gangs netted higher amounts. In reaction - and as in many other countries - cash holdings at branches were reduced by frequently transferring cash to large, well-protected sites. Our sample robberies involve smaller amounts stolen and were often perpetrated by individuals desperate enough to take the risk (GDP per capita in Colombia averaged around USD 4,000 during the sample period).
} 
bank robberies were carried without arms, in 89 percent firearms were observed, and the rest were carried out with the use of so-called white weapons - that is, knives and sharp instruments.

The second dataset is a credit register that contains information about individual commercial loans reported by financial institutions to the Superintendencia Financiera de Colombia, the regulator of Colombian's financial system. ${ }^{34}$ This dataset provides a detailed look at all the loans granted by the financial system to firms on a daily basis. Characteristics such as loan maturity, collateral, interest rate and amount, and (crucial for our purposes) the exact date of origination are included from 1998:12 to 2010:12. The dataset contains 2.5 million individual loan observations made to a total of 32,965 different firms by any of 120 different financial institutions. Given that we are interested in understanding the role of emotions in the process of granting loans, we focus only on new loans at origination (the terms of most outstanding loans either cannot be or likely will not be adjusted in such a short time window). This corresponds to 316,138 loan observations.

While we do not know the specific branch at which a loan was granted, we do have information on the physical location of the firm at a municipal level. Therefore, under the assumption that firms go to the nearest branch, ${ }^{35}$ we can determine in which municipality the loan was granted. However, if there is more than one branch of the same bank in a given municipality, we are not able to identify in which of them the loan was granted and

\footnotetext{
${ }^{34}$ The dataset was provided to us thanks to a direct link between one of the authors of this paper with the Central Bank of Colombia.

${ }^{35}$ This assumption is consistent with the extant empirical evidence in, e.g., Petersen and Rajan (2002), Degryse and Ongena (2005), Alessandrini, Presbitero and Zazzaro (2009), Agarwal and Hauswald (2010) and Herpfer, Schmidt and Mjøs (2017). See also the reviews in, e.g., Cerqueiro, Degryse and Ongena (2009), de Blasio (2009), and Degryse, Kim and Ongena (2009).
} 
consequently our exercises will be based on the bank-municipality level, and not on the bank-branch level for which the robbery information is available.

Clearly this approach may affect our results. The effect of a bank robbery might be weaker for example in geographically large areas with few branches or intensified in densely populated municipalities, where there may be several branches of the same bank located within a very short distance of one another, sometimes even within one or two blocks. Given this proximity of branches in a densely populated municipality, news may spread quickly from one branch to another. Thus, the effect of a bank robbery might be propagated across branches in the same municipality. Employees of other branches may very well feel terrified of having to go through a similar experience and, given this "emotional contagion" (e.g., Hatfield, Cacioppo and Rapson (1993)), they might react accordingly. Therefore in (unreported) robustness exercises we study municipalities with a geographical area smaller than 400 square kilometers, ${ }^{36}$ and find economically somewhat larger effects; or alternatively we include interactions with measures for the density of branches of the robbed bank at a municipal level (i.e., the number of branches per square kilometer) and also in this set of exercises indeed find such an effect.

Finally, in terms of the data we employ, we note that the auxiliary information on firm characteristics, such as their physical location, industry, and financial statements, is provided on a yearly basis by the Superintendencia de Sociedades, the government institution that regulates non-financial firms.

\footnotetext{
36 There are 1,122 municipalities in Colombia distributed over a total surface area of 1,141,748 square kilometers, i.e., the average municipality covers 1,027 square kilometers. Of the 246 municipalities in our sample, 109 cover a larger area.
} 
As previously mentioned, we focus on the loans that were granted up to 90 days before and up to 90 days after a robbery. ${ }^{37}$ Restricting our sample to this event window helps us to rule out structural changes in the process of granting loans - that is to say, monetary policy changes, internal organizational changes, or even changes of loan officers. In addition, and in order to limit the probability that our results will be driven by differences in the loan applicants, we include only the firms that get loans both before and after the robbery in the treatment group or in the control group. ${ }^{38}$ After including these adjustments to our sample, we end up with 389 bank robberies. Of these, 224 are bank holdups, 151 teller holdups, 6 tunneling, and 2 impersonating staff.

Our final dataset consists of 3.17 million loan observations, which comprises 35,487 that were granted by the robbed branches and 3.13 million that were granted by other branches in the rest of the country. These loans were provided by a total of 1,649 branches of 28 banks to any of 17,067 firms in 246 different municipalities. Table 1 provides further sample details.

\section{V.RESULTS}

\section{Main Findings}

Table 2 shows detailed summary statistics of the variables used in this study. Our

\footnotetext{
${ }^{37}$ In unreported exercises we re-estimate our specifications using different event windows (30, 60, and 120 days). In all the cases the results are consistent with our main finding, and for a window of 60 days in particular the signs and significance of most of the coefficients remain unchanged.

${ }^{38}$ Not imposing this restriction leaves our findings virtually unaffected confirming that the composition of firms does not play a major role in determining our findings.
} 
dependent variables correspond to the loan characteristics: Maturity, Collateral, Collateralization, Interest Rate, and Loan Amount. The mean maturity is 8.7 months, around 18.4 percent of the loans are required to pledge collateral and the average collateralization is 15.4 percent. The mean interest rate is 17.5 percent and firms are granted loans of COP 927 million (about USD 515 thousand) on average. However, as evidenced by the standard deviations, there is a substantial variation in the loan conditions.

[Table 2 around here]

As a part of our independent variables we include relationship and firm characteristics to control for the creditworthiness of the borrower. Among relationship characteristics we include the Length of Relationship, which measures the stock of private information about the borrower that the bank has acquired (Petersen and Rajan (1994), Berger and Udell (1995)). The average Length of Relationship in our sample is 14.2 quarters. We also include Main Bank, which indicates whether the loan is granted by the firm's primary source of financial services, and capture the scope of the relationship. In our sample, about 20 percent of the loans are granted by the firm's main bank.

Among the firm's characteristics we include a Small Firm dummy, as an indicator variable for the size of the firm. Small firms are generally considered to be less transparent and have less bargaining power than their larger counterparts. In our sample, about 30 percent of the loans are granted to small firms. We also include Age as Borrower as a measure of the amount of public information available about the firm (Petersen and Rajan (1994), Berger and Udell (1995)). In our sample, the average Age as Borrower is 26.8 
quarters. Additionally we include Number of Relationships, which is measured as the number of banks with which the firm has an outstanding loan prior to the origination of the new loan. The average Number of Relationships in our sample is 6.0. Finally, we include Arrear ( $t-1)$ and Firm Rating as measures of the quality of the borrower. Arrear (t-1) indicates whether a firm had an arrear, in at least one of its loans, up to one year prior to the origination of the new loan. About 10 percent of the loans in our sample were granted to firms that had an arrear the year before the origination of the new loan. Firm Rating is the average quality rating of the outstanding loans of the firm. The quality rates are observable by banks and range from 1 to 5 , where 1 indicates poor quality and 5 good quality. The average Firm Rating in our sample is 4.9.

Considerable insight can be obtained simply by comparing the loan and firm characteristics of the robbed branches and the branches in the rest of the country (in robustness exercises we will report in the rest of the region). Table 3 shows the differences in means between these two groups of branches for each of the aforementioned variables, both before and after the bank robbery. The last column presents a test of the differences in differences. For the loans granted before the bank robberies we do not find significant differences for Collateral. However, we do find significant differences for Maturity, Collateralization, Interest Rate, and $\ln ($ Loan Amount). These differences might be explained by differences in the characteristics of the borrowers. And consistently, we find significant differences in all the relationship and firm characteristics. Moving to the loans granted after the bank robberies, we find significant differences for all the loan conditions, except for Interest Rate. The differences in the relationships and firm characteristics are similar to the ones found for the loans granted before the robbery. That is, the differences 
between the clients of the two groups remain the same. The test of the differences in differences suggests that there are significant changes in the conditions of the loans granted by the robbed branch after the bank robbery. Moreover, the test suggests that the characteristics of the corporate clients of the robbed branches versus the control branches remain the same before and after the robbery.

[Table 3 around here]

To better illustrate where identification of the impact comes from, Figure 1 presents the trend of each of the loan characteristics, by robbed branches and control branches. The horizontal line represents the dates of the robberies. Inspection of the graph for Maturity suggests the presence of similar trends for the robbed and the control branches. The gap between the two lines, however, is reduced after the bank robbery. For Collateral and Collateralization, similar trends are observed for both groups, although the almost nonexistent and small gap, respectively, between them increases substantially after the bank robbery. For the Interest Rate similar trends are also observed. However the interest rate seems to reach lower levels for the robbed branches after the robbery. For the Loan Amount the trends of the two groups are not easily comparable due to high volatility, as evidenced by the large confidence intervals. The gaps between the two groups, however, seem to be altered after the robbery. In Figure 2 we display similar graphs after exactly matching individual loans on Length of Relationship, Main Bank, Small Firm, Age as Borrower, Number of Relationships, Default (t-1), and Firm Rating (we return to this matched 
subsample later, in robustness exercises). The trends are similar to the ones reported in Figure 1.

[Figures 1 and 2 around here]

As previously discussed, we use a difference in differences approach to measure what effect a bank robbery has on loan conditions compared to branches in the rest of the country. Our main results are shown in Table 4 Panel A and comprise for each dependent variable five different models. Model I corresponds to the model presented in Equation (1). Model II, includes an interaction term with the variable $\ln$ (Days After the Robbery). This term allows us to test if the effects on the loan conditions gradually disappear as the number of days after the robbery increases.

In Models III, IV, and V we include interactions with characteristics of the bank robberies. In particular, we include Firearm, a dummy for the robberies that were made with the use of firearms; and Robbed Amount over Deposits, a variable that measures the amount stolen as a percentage of the total deposits of the robbed branch. We noted earlier that the amounts robbed are tiny during the period of analysis and the average (median) of this variable equals only $0.027(0.0029)$ percent. We also note that both variables vary only at the branch level, such that double interaction terms with Branch Robbed for example are fully subsumed in the set of up to 150,699 Branch-Event Fixed Effects. In Appendix Table A.4 we report the mostly unchanged estimates for the resultant two representative models when comparing to branches in the rest of the region, to account for the possibility that the bank robbery was part of a local crime wave. 
With these variables we aim to test if the degree of violence employed in the bank robbery has a differential effect on the loan conditions. Moreover, we aim to rule out the possibility that our results are being driving by monetary considerations rather than by the psychological effects experienced by the employees.

[Table 4 around here]

The results strongly suggest that there is an overall increase in the length of Maturity after a bank robbery, by 0.7 months in Model I. According to Model II maturity increases by 3.3 months right after the robbery but gradually decreases as the number of days after the robbery increases. The effect halves within 10 days and vanishes entirely around 112 days after the robbery. We do find a differential, economically relevant effect for the robberies that were carried out with the use of a firearm, but the effect is estimated imprecisely. The amount stolen does not have an effect on Maturity, which given the variable's small economic size should not come as a surprise.

We also find an increase in collateral requirements as shown by Model I. And, when we include the interaction with $\ln$ (Days after the Robbery), we find that the likelihood that a firm is required to pledge collateral increases by 3.4 percent right after a bank robbery. And this probability decreases as the number of days after the robbery increases (Model II). The effect is halved in less than 8 days and ceases 64 days after the robbery. Nonetheless, the results presented from Model III suggest that the increase in the likelihood of collateral being required is present only when firearms are used during the bank robbery. Branches robbed without the use of firearms experienced the opposite effect. Moreover, Models IV 
and V show that the effects of a bank robbery on Collateral are also not influenced by the amount stolen.

Similarly, the results suggest that there is an effect on Collateralization (Model I). However, the immediate increase of 3.9 percent in the level of collateralization also dissipates over time (Model II). The effect is halved 5 days after the robbery and ceases 28 days after the robbery. As with Collateral, this pattern for Collateralization is only present when firearms are used during the bank robbery. When arms but not firearms or no arms at all are used, the effect is the opposite. Models IV and V, again, show that the effects of a robbery on Collateralization are not influenced by the amount stolen.

For the Interest Rate we find that there is an effect that persists 90 days after the robbery. The effect corresponds to a decrease in the interest rate of 0.34 percent (Model I). ${ }^{39}$ However, as Model III suggest, this decrease in the interest rate is only present in the branches in which firearms were used during a robbery. For the rest of the branches the interest rate increases. It rises by 2.6 percentage points right after the bank robbery and decreases as the number of days after the robbery increases. Models IV and V, again, show that the effects of a bank robbery on the Interest Rate are not influenced by the amount stolen.

Finally, we also find that there is an increase in the Loan Amount after a bank robbery. The increase corresponds to 3.7 percent of the mean loan amount (Model I). The effect,

\footnotetext{
${ }^{39}$ The semi-elasticity (i.e., as a percentage of the mean dependent variable) is equal to -2.0 percent, whichin terms of absolute value - is the smallest of all studied loan terms. This is consistent with the possibility that credit spreads, but not other loan terms, are "anchored" - that is to say, that the path of credit spreads since the last loan influences the level at which a firm can currently borrow (Dougal, Engelberg, Parsons and Van Wesep (2015)).
} 
however, do not seem to decrease over time or to be affected by the use of firearms during the robbery. Finally, the amount stolen does not have an economically significant effect on the Loan Amount. This further shows that our results are not being driving by monetary considerations. ${ }^{40}$

The results are consistent with the hypotheses $(\mathrm{H} 1-\mathrm{H} 3)$ that, due to a combination of emotions experienced after a bank robbery, loan officers deviate from their traditional approach to processing loan applications. However, as the number of days after the robbery increases, most of these emotions disappear and loan officers return to their usual approach to dealing with clients. Moreover, the effect on loan conditions seems to depend on the degree of violence involved in the robbery.

In the case of robberies involving firearms, loan officers seem to adopt strict avoidance behavior (H4): They decrease the likelihood of having contact with clients in the near future by lengthening maturity and by increasing the collateral requirements of loan contracts. Loan officers also reduce the negotiation time spent with applicants by granting loans with lower interest rates. In contrast, loan officers that are present during less violent robberies decrease collateral requirements and charge a higher interest rate.

We note that the relative size of each of the effects may be influenced by the intermediation margin that loan officers have on each of the loan conditions (the discretion that loan officers have for each variable) and by changes in the volume and quality of business credit demand. However, our results are robust to different specifications that

\footnotetext{
${ }^{40}$ In unreported results we estimate an additional specification, one for each of the loan conditions, where we include interactions with an indicator variable that equals 1 when the amount stolen is very high (we use various percentile cutoffs) and 0 otherwise. The coefficients on these interactions are also not statistically significant.
} 
include as control the "other" loan characteristics (see Appendix Table A.5) ${ }^{41}$ or 10,219 business-year:quarter fixed effects (see Table 4 Panel B). The latter set of fixed effects is included in the spirit of Khwaja and Mian (2008) to account for changes in credit demand. ${ }^{42}$ Our results are also robust to the exclusion of the set of branch-event fixed effects (see Appendix Table A.7).

We also study how individual loan ratings are affected (even though loan officers may not have full discretion, for all loans, in setting a new credit rating) and find that better loan ratings are recorded after the robbery, but that this effect is not influenced by the time since or the intensity of the robbery.

[Table 5 around here]

Finally, we are curious about the non-performance of the loans that were granted after a robbery. If loan officers set loan terms optimally before the robbery, ceteris paribus we would expect loans granted after a robbery to be more likely to eventually be nonperforming.

\footnotetext{
${ }^{41}$ Self-evidently these are "bad" controls (Angrist and Pischke (2008)) given that they are also affected by the robbery. Appendix Table A.6 shows this may be the case as loan terms seem correlated in general.

${ }^{42}$ We combine firm size (4 groups), age (3), number of relationships (4), default (2), rating (2), and industry (10), for a total of 1,920 possible groups of which 787 are filled, which combined with the year:quarter dimension results in 10,219 business-year:quarter fixed effects. With other comprehensive sets of fixed effects already included, maximizing saturation inevitably comes at the cost of attrition in the number of observations effectively used. See also the discussion in Degryse, De Jonghe, Jakovljevic, Mulier and Schepens (2019), and the applications in, e.g., Edgerton (2012), De Jonghe, Dewachter and Ongena (2016), Auer and Ongena (2019), De Jonghe, Dewachter, Mulier, Ongena and Schepens (2019) and Morais, Peydró, Roldan-Pena and Ruiz-Ortega (2019).
} 
This is exactly what we find and report in Table 5. The probability of arrears on loans increases by 0.8 percentage points after a robbery (its mean equals 2.7 percent), while the time in arrears increases by 0.019 quarters or 2 days (its mean equals 5 days). The half-life of these effects equals 12 and 7 days, respectively, in line with our findings so far (though the estimated coefficients in Models (2) are not statistically significant). Figure 3 presents the trend of the length of arrears, by robbed branches and control branches. The immediate increase on the length of arrears after the robbery and its subsequent dissipation is also clear from the graph.

When we add the loan characteristics in Models (3) and (4), estimates become weaker, suggesting that indeed loan terms were potentially set (somewhat) sub-optimally. Of course, after a few weeks loan officers could have started monitoring more to counteract the sub-optimality in the previously granted loan terms. In Appendix Table A.8 we report the mostly unchanged estimates when comparing to branches in the rest of the region.

[Figure 3 around here]

\section{Further Explorations}

\section{a. Falsification Tests}

We run a number of different falsifications tests. First, we assess the impact of placebo visitations (by imaginary robbers) to all branches that were eventually robbed, one year prior to the first actual robbery that took place within our sample period. Even though this is a somewhat mechanical placebo that does not entirely exclude the possibility that the branch was already an attractive target at the time of this visitation, we find that our main findings of interest (i.e., reversal and firearm) are no longer statistically significant and/or 
economically relevant in most specifications (see Appendix, Table A.9). We also place the placebo robbery half a year prior to the actual robberies, but the results are very similar.

Next, we randomly select from the active branch-year combinations (with loans being granted) and then pick a random day during the year the placebo robbery would occur. Table 6 Panel A reports the mostly insignificant and often differently signed estimates.

[Table 6 around here]

Finally, in a demanding test we pick a random day for those branch-year combinations that were false positives for our simple prediction model (introduced in Footnote 14) - that is to say, it was predicted that these branches would be robbed during the year but, actually, they were not. Estimates are in Table 6 Panel B and again are mostly insignificant and differently signed than the main estimates we presented earlier.

\section{b. Revisitations}

Some branches are robbed multiple times, and as noted earlier this is an often observed phenomenon in robbery statistics. In our selected sample there are in total 40 "revisitations". Revisitations can affect our results in several ways: First, if they occur within a short period of time, their effects on the loan officers and consequently on the loan conditions might overlap, making it difficult to disentangle the effects of a particular event. Second, if revisitations are more spread over time, security at the robbed branch could have been improved and in addition loan officers could be better prepared to cope with the traumatic event should a robbery occur. 
In order to make sure that the effects of revisitations are not affecting our results, we exclude the bank robberies carried out in branches that were robbed more than once within our sample period by relying on our information on the exact address of the robbed branch. The estimates are presented in Appendix Table A.10 and are very similar to those already reported. The magnitude of the coefficients decreases, but their signs remain the same and also the level of statistical significance overall remains almost unchanged. This suggests that our results are not being driven by the effects of revisitations.

In addition, we analyze separately what is the effect of revisitations. If loan officers of branches that were previously robbed receive training to cope with this type of violent event or become otherwise inured to it, the effect of revisitations on loan conditions should be less pronounced. On the other hand, if no psychological treatment is received after a robbery, ${ }^{43}$ loan officers might experience a deeper trauma after a new incident. We reestimate our model for the sample of robberies that correspond to revisitations. The results, presented in Table 6 Panel $\mathrm{C}$, show that revisitations have bigger economic effects on loan conditions than do first time robberies. This suggests that previously robbed branches are not better prepared to deal with a new robbery. ${ }^{44}$

\footnotetext{
${ }^{43}$ Structured interviews with current managers at the Central Bank of Colombia responsible for bank security indicate that it is unlikely that employees in the past received any treatment or even formal debriefings following robberies. Even in the current laws or protocols there are no specific provisions for such ex post activities.

${ }^{44}$ We also interact the after and days after variables with the number of robberies a branch experienced during the last three years or alternatively a dummy that equals 1 if at least one robbery had already taken place at the branch and 0 otherwise, but we find similar results.
} 


\section{c. Further Matching}

In our previous exercises we have already a fair degree of matching as we compared a treated with a control group of loans granted to firms that obtain loans both before and after the robbery, and in one exercise in robbed branches and branches in the rest of the region.

We now, in addition, exactly match individual loans on Length of Relationship, Main Bank, Small Firm, Age as Borrower, Number of Relationships, Default (t-1), and Firm Rating (as in Figure 2). Results, in Table 6 Panel D, show that-even though the set of loans granted shrinks by almost two-thirds - this exact (and exacting) matching exercise does not neutralize the results.

\section{d. Bank Type and Number of Employees at the Branch}

Next we consider bank type. Given stricter regulations in their countries of origin, branches of foreign banks may provide better protection and training for their employees, such that in the case of a robbery their loan officers are less traumatized. Similarly given their status within the governmental administration, employees at state banks may also receive better protection and training. Interacting the variables After and Days After the Robbery with a dummy for branches of either foreign or state banks (in unreported regressions), we indeed observe a statistically significant reduction in the effect of a robbery across loan terms for these types of banks.

Loan officers at branches with fewer employees are more likely to have witnessed the robbery firsthand and it may also, given the size of the branch, be more difficult for them to stay off work afterward. Hence we expect loan terms at small branches to react more 
strongly to a robbery. ${ }^{45}$ We therefore interact the variables After and Days After the Robbery in Panel A of Table 7 with a dummy for branch size, which equals 1 if the branch has eight or fewer employees, ${ }^{46}$ and 0 otherwise, and in Panel B of Table 7 with the logarithm of the Number of Employees itself (in which case opposite signs on the interactions are expected).

[Table 7 around here]

We find that the impact of a robbery on maturity and collateralization is indeed larger at smaller branches but that its half-life remains mostly unaffected, which is consistent with our interpretations so far.

\section{e. Small Loans, Large Firms, Long Relationships}

Next we focus on small loans only, given that these loans are more likely to be approved by local loan officers and not by their superiors located elsewhere. ${ }^{47}$ In Panel C of Table 7 we therefore restrict the loan amount to the lowest quartile (i.e., below USD 16,650) to

\footnotetext{
${ }^{45}$ On the other hand, a branch having fewer employees could also increase the probability that the branch will be temporarily closed and loan officers at small branches may ceteris paribus be more familiar with their customers.

${ }^{46}$ We obtain the number of employees at the bank-municipality level from the Superintendencia Financiera de Colombia. For each year we collect the year-end count, starting in 2005 (we use the 2005 count also for earlier years). In total, 10 percent of all bank branches have eight or fewer employees (findings are similar if we use a 25 percent cutoff; i.e., 10 employees). This number also includes part-time, security, cleaning, and centrally located administrative personnel, none of whom decide on loan terms. Hence we expect many loan officers to have had direct contact with the robbers in such branches.

47 While a rich literature describing the stages, incentives, and information collected during the loan application process (e.g., Liberti and Mian (2009), Agarwal and Hauswald (2010), Hertzberg, Liberti and Paravisini (2010), Berg, Puri and Rocholl (2013)) suggests that individual loan officers commonly decide on smaller and simpler loans - while credit committees will deal with larger and more complex credit dealswe still lack comprehensive bank-level evidence on the precise loan amounts (and other terms) various commercial banks use as hurdle rates, and how these hurdle rates may have shifted over time as a result of bank mergers and credit scoring technology for example.
} 
retain 279,022 loans and interact all variables of interest with the dummy for the number of employees being equal to or less than eight, ${ }^{48}$ and in Panel D interact them with a loan amount dummy that equals 1 if the loan amount is below the quartile cutoff and 0 otherwise.

We find an even more pronounced effect of bank robberies for small loans in small branches, and in general. This is consistent with the fact that emotions are more prone to be transmitted from loan officers to loan terms for loans approved by local loan officers, who are the employees that are directly exposed to the violence of a bank robbery.

We then analyze if there is a differential effect on the loan conditions of loans granted to large firms. As these firms typically receive more transactional loans (e.g., Berger and Udell (2006)). they might be less affected by the emotions experienced by loan officers. We therefore, expect to find a less pronounced effect of a bank robbery on loans granted to big firms. Finally, we look at loans granted to firms that have already had a long relationship with the bank. On the one hand, these loans may be more relationship-based and require more personal attention; on the other hand, the loan officer may feel more comfortable with the firm's managers given their long-standing personal ties. In line with the latter argument, we expect to find a less pronounced effect of a bank robbery on loans granted to a firm that has had a long relationship with the branch.

We estimate two additional sets of specifications, for each of the loan conditions, which include interaction terms with indicator variables for large firms (upper $25^{\text {th }}$ percentile

\footnotetext{
${ }^{48}$ Small loans are more often granted to small firms, which are less likely to borrow both before and after the robbery. Results are similar when employing a 50 percent loan amount cutoff (i.e., USD 83,250) and when interacting with the logarithm of the number of employees or the 25 percent number of employees cutoff.
} 
based on the total assets of the firms) and the length of the relationship. ${ }^{49}$ Our (unreported) results suggest that the effect of a bank robbery is less pronounced for loans granted to large firms. These results, however, are not statistically significant. And we similarly find that - if anything - the length of the relationship somewhat mitigates the effect of a robbery, but the effects are not particularly precisely estimated. ${ }^{50}$

\section{Potential Alternative Explanations}

\section{a. Accumulation of Work}

There is no regulation or standard practice in Colombia that prescribes how many days a branch should be closed following a bank robbery. Instead, each branch arbitrarily chooses the number of closure days, if any. This could partly affect our results, as the closure of a branch might generate an accumulation of applications to be dealt with once the branch is reopened. If the number of closure days is high, the excessive amount of work required subsequently might alter the loan officer's response to a particular loan application. If this is the case, we should be able to find a differential effect for branches with large closure periods.

\footnotetext{
49 As most firms and bank branches in our dataset are one-(wo)man operations, with potentially limited turnover in personnel, the length of the firm-bank relationship may be a reasonable proxy for the length of the personal relationship between an individual firm manager and loan officer. Notice that this may not be the case for large firms and/or banks where personal ties may need to be distinguished from institutional ones (e.g., Lehmann and Neuberger (2001), Herpfer (2018), Karolyi (2018)).

${ }^{50}$ While few firms maintain only one bank relationship in Colombia (see also Qian and Strahan (2007)), we re-estimate the effect of robberies on lending terms for these firms because these borrowers are less likely to have an immediate choice of another lender right after the robbery. The estimated coefficients are similar in sign and magnitude but the much lower number of observations robs most estimates of their statistical significance.
} 
As we do not have separate information on branch closures, we use the number of days during which a robbed branch did not grant any commercial loans as a reasonable proxy. Based on this measure, we find that in 119 bank robberies (out of the 389 bank robberies included in our selected sample) the branch is not closed the day after the bank robbery. In the rest of the bank robberies there are closures (or periods of not granting commercial loans) that vary between 1 and more than 15 days. We interact our main specification with the number of closure days. The results (unreported), however, are not statistically significant and small in magnitude. This suggests that the potential effects of branch closures are not driving our results. If anything the sign of the coefficients suggests that the effect of a bank robbery on loan conditions decreases with the number of closure days. This is likely to be associated with a lessening of the symptoms experienced by the loan officers.

Hence our findings are not consistent with the possibility that branches close and work accumulates. But work could also accumulate for individual loan officers, because other loan officers call in sick, spend time in counseling to mitigate distress symptoms (LeemanConley (1990)), or seek to quit their jobs altogether (Miller-Burke, Attridge and Fass (1999)).

Yet, none of these actions are very likely in Colombia. Due to low sick-leave payments, ${ }^{51}$ sick leave is expected to be less common there than in many other countries around the

\footnotetext{
${ }^{51}$ Absences related to illness are typically found to be more common in countries where periods of full pay during temporary incapacity are predominant than in countries where this is not the case (see, e.g., Gimeno, Benavides, Benach and Amick (2004)). In Colombia employees on sick leave receive only 66.7 percent of their salary during the first three days of absence, paid by their employer. Afterward, payments are made by the General Health and Social Security System, but obtaining such payments may take time and effort. It is perhaps not surprising then that in a report published by the International Trade Union Confederation (ITUC)
} 
world; counseling is typically not provided; and quitting and/or switching jobs is very difficult in the short run as the unemployment rate ranges between 10 and 15 percent during the sample period (which is always almost 5 percentage points higher than in the rest of South America), the labor market is rigid, and unemployment benefits were-before 2013 - close to zero. All of this makes it unlikely that work would accumulate for a few resilient loan officers, while the aforementioned branch closure evidence suggests that work accumulation cannot explain the direction of the change in loan terms immediately after the robbery in any case.

To deal with the workflow more easily, loan officers could in general cherry-pick applications. ${ }^{52}$ They could choose to review the most easy-to-approve and important loans immediately after the robbery, while deferring other more difficult applications for later. Granting easier (collateralized and safer; i.e., with longer maturity and a lower interest rate) and more important (i.e., larger in size) loans first would be observationally equivalent with our findings so far on loan terms, but it would not be consistent with the worse performance on these loans we observed in Table 5.

[Table 8 and Figure 4 around here]

in May 2014, Colombia was listed as one of the "worst countries in the world to work in" and was found to be comparable to Cambodia and Zimbabwe.

52 Alternatively, interim employees could be hired leading to a temporary loss of private and/or soft information, leading to more lending based on publicly available hard information. But we did find that -if anything - the length of extant bank-firm relationships somewhat mitigates the effect of a robbery, which would not be the case if a loss of information drives our findings. 
Table 8 further demonstrates that the number of loans originated per day drops significantly after a robbery (its mean equals 2), with a half-life of 7 days, to recover fully after 44 days, especially when a firearm is used; hence, loan officers may temporarily seek to avoid customers, but even when granting the "easy" loans first they fail to correctly set conditions (as evidenced in Table 5), potentially due to their lack of concentration as a consequence of the robbery. Figure 4 provides the common pre-trend graph for these estimations.

\section{b. Changes in Bank Policies}

After a robbery occurs, the bank may revise its risk policy and shift its credit origination from riskier loans to safer loans. While not impossible we think that the immediate reaction and short half-life of the observed changes are not consistent with bank-wide policy changes. For example in Dessaint and Matray (2017) it takes more than 180 days to observe the maximum corporate response, which comes with a half-life of one year or more..$^{53}$

But to investigate this possibility further we check if loan terms change across the affected bank's branches in a region (Appendix Table A.11). So now the treatment group contains the loans granted within the region but not the municipality where the robbery took place, while the control group comprises all loans granted by other banks in other municipalities. We find no effect in most of the loan terms, and for the ones for which we do find an effect it is three or more times smaller and no reversal or firearm effect is found. This is not

\footnotetext{
53 The authors study how managers respond to the occurrence of a hurricane event when their firms are located in the neighborhood of the disaster area. They find that the managers increase the amount of corporate cash holdings (and express more concerns about hurricane risk in 10-Ks/10-Qs) even though the real risk remains unchanged.
} 
consistent with changes in regional bank policy, which likely would be applied homogenously, ${ }^{54}$ and would take some time to implement.

We then check if loan terms change across the entire affected bank after a local robbery, and in unreported regressions we find that they do somewhat but that this potential contagion effect is small (and close to economically meaningless). Recall that we find a similar contagion when we assess how the affected bank branch density at the municipal level reinforces changes in loan terms.

\section{c. Effect on Customers}

While most if not all employees at the robbed branches will experience the robbery, only few customers, present in the branch at the time of the robbery, will. ${ }^{55}$ However in principle not only bank employees but also customers might feel threatened and experience stress. Their reaction may have an impact on their demand for credit at the robbed bank and also on the level of deposits they keep in that bank.

Although some of our strongest findings with respect to the collateralization of loans and the half-life of the impact overall are difficult to square with the reaction actually coming

\footnotetext{
${ }^{54}$ To reduce the possibility that policy implementation is homogenous within banks, we run a Harvey (1976) heteroscedastic loan pricing model (as in Cerqueiro, Degryse and Ongena (2011) and Cerqueiro, Degryse and Ongena (2013)) for the entire period with all other variables as explanatory, and we select only those banks where the bank-specific dispersion (i.e., the loading on the bank dummy in the so-called variance equation) of the loan rates is in the lowest 25 percent: for those banks we expect policies in general to be implemented more homogenously. As Appendix Table A.12 demonstrates, results are unaffected, and-if anything - are actually stronger for those banks (a 50 percent cutoff gives very similar results, so we leave them unreported).

${ }^{55}$ Loan officers (present during the robbery or closely connected to those present) may be responsible for granting hundreds of loans within our estimation period, but the few customers present will be connected to at most a handful of loans. Indeed the average (median) time between credit transactions at the bank-firm level in our sample is equal to 7 (4) months. For a full hour of time spent at the branch per credit transaction, and with 25 working days per month and 9 working hours per day, this implies a probability of being present when the robbery takes place of 0.06 percent $(0.11$ percent $)(=1 /(7$ or $4 * 25 * 9)$. In contrast full-time employees at the branch may spend 90 percent of their working hours there implying that an employee is more than $800(1,500)$ times more likely to be present in the vicinity of the robbery than is a customer.
} 
from the demand side ${ }^{56}$ ideally we would like to analyze what is the effect of a bank robbery on the number of applications and especially the loan terms that are requested by the applicants. In the absence of this information, ${ }^{57}$ we use the total number of loans granted by each branch as well as the total amount lent before and after the robbery to determine if customers stop going to the robbed branch. We replicate Table 8 but now eliminate the restriction that a firm has to be granted loans in the period before and after the robbery, so that we can take into account the possibility that customers stay home longer after a robbery. However, in further unreported regressions we find that overall the drop in the number of loans obtained is substantially smaller for all firms than for those firms that borrow before and after a robbery. This suggests that customers do not stop applying for new credit at the robbed branch.

Moreover, the results for the total amount lent (its mean equals COP 222,144 million), presented in Table 9, suggest that there is a slight increase in the total amount lent by the robbed branches. The increase corresponds to 2.8 percent of the average amount lent by a

\footnotetext{
56 It is difficult to interpret our finding that collateral increases as a consequence of scared customers demanding such an increase and robbed branches being obliging to these demands in order to attract or retain these customers. In addition, the half-life of the phenomenon we observe is 1 to 2 weeks (for robberies involving a firearm), which fits with the continuous presence of employees at the branch, but not with the low frequency of presence of customers at branches. Put differently, if in the unlikely case that customers (not present during the robbery) would actually be strongly shocked hearing the news of the event, the effects would likely mostly wear off upon recurring visits by these customers to the scene of the crime, and hence the phenomenon's half-life would be much longer.

57 No credit register in the world records comprehensive application information yet. Jiménez, Ongena, Peydró and Saurina (2012) for example use the information requests lodged by banks to the credit register as a proxy for the number of applications. Only single-bank datasets contain detailed application information (e.g., Agarwal and Hauswald (2010), Brown, Kirschenmann and Ongena (2014)).
} 
branch. The results are robust to different specifications that include event fixed effects and branch fixed effects. ${ }^{58}$

[Table 9 around here]

On the other hand, if depositors are, after a robbery, afraid of losing their money, they might contribute to a run on the robbed branch (or other branches of the same bank) and withdraw all their money. Anticipating this, banks may actually transfer some extra liquidity to the affected branch(es). If on the contrary customers are afraid to go to the branch, they might decide to keep their money in the bank for a longer period than usual (even if they could withdraw from another branch, there are fees that might stop them from doing so).

To assess these possibilities we perform an exercise similar to the one performed for loan conditions, but we now use the amount of deposits as a dependent variable. The information on the amount of deposits is gathered from the website of the Superintendencia Financiera de Colombia. It is disaggregated at the bank-municipality level but it comes (unfortunately only) at a quarterly frequency.

Our (unreported) estimates suggest that there is only a modest increase in the level of deposits in the quarter following a bank robbery (which is equal to one-fifth of the standard deviation in deposits). This is consistent with the idea that depositors are afraid to visit the

\footnotetext{
${ }^{58}$ As to changes in other loan terms we note that if borrower preferences did change, this might especially affect relationship loan outcomes. Recall from earlier discussions that - if anything - the length of the relationship somewhat mitigates the effect of a robbery, which could imply that borrower preferences after a robbery change in the opposite direction to those of loan officers.
} 
bank and prefer to keep their deposits in the bank for a longer period, or that the bank provides some more liquidity to the affected branch(es). However, the small effect we find is not sensitive to the time that has elapsed since the robbery, the degree of violence used, or the amount stolen, nor to the type of deposit (i.e., current account, fixed deposit, savings account) involved. Hence, changes in deposits do not seem to provide an alternative explanation for the changes in loan conditions we estimated earlier.

\section{An Alternative Setting: Local Team Winning Soccer Games}

At the municipal level, the local team winning soccer games in the national cup tournament may arouse strong positive emotions (à la Edmans, GarcÍa and Norli (2007) and Kaplanski and Levy (2010)), ${ }^{59}$ although potentially not of the same intensity as a robbery. We therefore collect for our sample period all the games in this tournament and their outcomes and run specifications for the same outcome variables and with a concurrent set of independent variables and fixed effects. Estimates are shown in Table 6.

[Table 10 around here]

In Panel A we study the impact of the local team winning a game. The estimates in all cases have the opposite sign of the impact of the robberies, are always highly statistically significant, are half to one-third in absolute size, and have a half-life of one or two days.

\footnotetext{
59 Soccer is the most popular sport in Colombia, with-according to the International Federation of Association Football (FIFA) — close to 300,000 registered and 3 million active players (for a total population of almost 50 million inhabitants). The Copa (Colombia) Postobón (now called Copa Águila) was re-launched in 2008 and is contested by all 36 teams in the first and second divisions of Colombian football.
} 
In Panel B we study the impact of the local team playing in the cup, because even playing another game (after having progressed from the previous round of this knockout tournament) is "prestigious and rewarding" for local fans, especially for smaller teams that may rarely make it very far. The estimates basically confirm the estimates for the wins, but are less significant and smaller with an even shorter half-life.

\section{VI.CONCLUSION}

In this paper we study the impact of emotions on real-world decisions made by bank officers. We do so by analyzing the loan conditions of loans granted immediately after an exogenous violent event that is expected to have an effect on loan officers' emotions. The exogenous event we focus on is a bank robbery. Our study is the first that attempts to understand the link between loan officers' emotions and loan officers' decisions with regard to loan conditions.

We employ a difference in differences approach where the treatment group for each event corresponds to the loans granted locally by the bank whose branch was robbed, and the control group corresponds to the loans that were granted in the rest of the country (or region). In order to rule out structural changes in the process of granting loans we define an event window for each bank robbery that retains only those loans granted up to 90 days before and up to 90 days after the bank robbery. In addition, we include a set of branchevent fixed effects in order to account for any observable and unobservable branch-specific heterogeneity across time.

We find significant differences in the conditions of the loans granted after a robbery, suggesting that loan officers do change their approach to decision-making following this 
event. In general loan officers seem to adopt so-called avoidance behavior: they decrease at once the likelihood of having contact with the client by lengthening the maturity of the loan contract and by demanding more collateral, thereby reducing the probability of loan non-performance (and consequent dealings with the client) prior to maturity. However, these effects dissipate as the symptoms experienced by the loan officer wear off. In addition, loan officers grant loans with ceteris paribus slightly softer loan conditions: lower interest rates and a higher loan amounts, possibly reflecting a reduced willingness to spend face-to-face negotiation time with applicants.

These effects, however, vary depending on the severity of the robbery. In robberies where the perpetrator carries a firearm, loan officers subsequently adopt stricter avoidance behavior, with longer maturities and higher collateral requirements, and lower loan rates and higher loan amounts. But for those robberies where no firearm is involved, collateral requirements and loan amounts initially drop while loan rates increase.

Finally, although in this study we analyze mainly a single type of event (bank robberies), loan officers (as might any individual) might experience a number of different events that could have an effect on their emotions and subsequently on the loan conditions they establish. Strategies for emotion regulation could help to mitigate the effects of emotions on loan conditions. In particular reappraisal (rather than suppression) strategies which consist in changing the way a situation is construed so as to decrease its emotional impact (and which consequently comes early in the emotion-generative process) may be successful, as it decreases emotion experience and behavioral expression, but has no impact on memory. In the case of a bank robbery reappraisal for example this could consist in stressing that the objective of the robbers was stealing, not hurting bank employees, that 
the safety measures in place did prevent the worst from happening and that the police were already closing in on the robbers thanks to the professional behavior of all bank staff that had to endure this robbery (Gross (2002), Fenton-O'Creevy et al. (2012)). Given that the cost to implement the professional psychological coaching on this account, not only for robberies but also for many other personal life changing events, is likely quite cheap compared to the economic cost of temporarily or permanently altered loan officer behavior, banks may want to consider to implement or extend such programs readily. 


\section{REFERENCES}

Abdellaoui, M., L'Haridon, O., Paraschiv, C., 2011. Experienced vs. Described Uncertainty: Do We Need Two Prospect Theory Specifications? Management Science 57, 1879-1895.

Agarwal, S., Ben-David, I., 2017. Loan Prospecting and the Loss of Soft Information. Journal of Financial Economics, Fortcoming.

Agarwal, S., Duchin, R., Evanoff, D., Sosyura, D., 2013. In the Mood for a Loan: The Causal Effect of Sentiment on Credit Origination. National University of Singapore, Singapore.

Agarwal, S., Hauswald, R., 2010. Distance and Private Information in Lending. Review of Financial Studies 23, 2757-2788.

Agarwal, V., Ghosh, P., Zhao, H., 2019. Violence and Investor Behavior: Evidence from Terrorist Attacks. Georgia State University, Atlanta GA.

Alessandrini, P., Presbitero, A.F., Zazzaro, A., 2009. Banks, Distances and Firms' Financing Constraints. Review of Finance 13, 261-307.

Angrist, J.D., Kugler, A.D., 2008. Rural Windfall or a New Resource Curse? Coca, Income, and Civil Conflict in Colombia. Review of Economics and Statistics 90, 191-215.

Angrist, J.D., Pischke, J.-S., 2008. Mostly Harmless Econometrics: An Empiricists Companion. Princeton University Press, Princeton NJ.

Aronson, E., 2012. The Social Animal. Worth Publishers, New York NY.

Auer, R., Ongena, S., 2019. The Countercyclical Capital Buffer and the Composition of Bank Lending. Bank for International Settlements, Basle.

Baele, L., Farooq, M., Ongena, S., 2014. Of Religion and Redemption: Evidence from Default on Islamic Loans. Journal of Banking and Finance 44, 141-159.

Baumer, T., Carrington, M.D., 1986. Robbery of Financial Institutions. U.S. Department of Justice, Washington DC.

Beck, T., Behr, P., Guettler, A., 2012. Gender and Banking: Are Women Better Loan Officers? Review of Finance 17, 1279-1321.

Becker, G.S., 1957. The Economics of Discrimination. University of Chicago Press, Chicago.

Bellucci, A., Borisov, A., Zazzaro, A., 2010. Does Gender Matter in Bank-Firm Relationships? Evidence from Small Business Lending. Journal of Banking and Finance 34, 2968-2984.

Berg, T., Puri, M., Rocholl, J., 2013. Loan Officer Incentives and the Limits of Hard Information. Humboldt University, Berlin.

Berger, A.N., Espinosa-Vega, M., Frame, W.S., Miller, N.M., 2005. Debt Maturity, Risk, and Asymmetric Information. Journal of Finance 60, 2895-2924.

Berger, A.N., Udell, G.F., 1995. Relationship Lending and Lines of Credit in Small Firm Finance. Journal of Business 68, 351-381.

Berger, A.N., Udell, G.F., 2002. Small Business Credit Availability and Relationship Lending: The Importance of Bank Organisational Structure. Economic Journal 112, $32-53$. 
Berger, A.N., Udell, G.F., 2006. A More Complete Conceptual Framework for SME Finance. Journal of Banking and Finance 30, 2945-2966.

Bernile, G., Bhagwat, V., Rau, P.R., 2017. What Doesn't Kill You Will Only Make You More Risk-loving: Early Life Disasters and CEO Behavior. Journal of Finance 72, 167-206.

Bons, S., 2015. Colombia's Next Challenge? A Psychologically Traumatized Society. Americas Quarterly Web Exclusive, September 25.

Brown, M., Kirschenmann, K., Ongena, S., 2014. Bank Funding, Securitization, and Loan Terms: Evidence from Foreign Currency Lending. Journal of Money, Credit and Banking 46, 1313-1554.

Brown, M., Westerfeld, S., Schaller, M., Heusler, M., 2012. Information or Insurance? On the Role of Loan Officer Discretion in Credit Assessment. University of St. Gallen, St. Gallen.

Brunello, N., Davidson, J.R.T., Deahl, M., Kessler, R.C., Mendlewicz, J., Racagni, G., Shalev, A.Y., Zohar, J., 2001. Posttraumatic Stress Disorder: Diagnosis and Epidemiology, Comorbidity and Social Consequences, Biology and Treatment. Neuropsychobiology 43, 150-162.

Cabas-Hoyos, K., Ospina-Buelvas, J., Lopez-Sierra, M.A., Ochoa-Reyes, A., UribeUrzola, A., Villamil-Benitez, I., Otero-Suarez, C., Cardenas-Lopez, G., 2016. Prevalence of Post-Traumatic Stress Disorder and Associated Events in Adults Victim of Displacement in the Colombian Caribbean. European Psychiatry 33, Supplement, S512.

Callen, M., Isaqzadeh, M., Long, J.D., Sprenger, C., 2014. Violence and Risk Preference: Experimental Evidence from Afghanistan. American Economic Review 104, 12348.

Cameron, L., Shah, M., 2015. Risk-Taking Behavior in the Wake of Natural Disasters. Journal of Human Resources 50, 484-515.

Campbell, D., Loumioti, M., Wittenberg Moerman, R., 2018. Making Sense of Soft Information: Interpretation Bias and Loan Quality. Harvard Business School Accounting and Management Unit, Cambridge MA.

Cerqueiro, G., Degryse, H., Ongena, S., 2009. Distance, Bank Organizational Structure, and Lending Decisions. In: Alessandrini P, Fratianni M \& Zazzaro A (eds.) The Changing Geography of Banking and Finance. Springer, New York NY, pp. 57-74.

Cerqueiro, G., Degryse, H., Ongena, S., 2011. Rules versus Discretion in Loan Rate Setting. Journal of Financial Intermediation 20, 503-529.

Cerqueiro, G., Degryse, H., Ongena, S., 2013. Using Heteroskedastic Models to Analyze the Use of Rules versus Discretion in Lending Decisions. In: Bell A, Brooks C \& Prokopczuk M (eds.) Handbook of Research Methods and Applications in Empirical Finance. Edward Elgar, London, pp. 216-237.

Cerqueiro, G., Ongena, S., Roszbach, K., 2016. Collateralization, Bank Loan Rates and Monitoring: Evidence from a Natural Experiment. Journal of Finance 71, 12951322.

Cesur, R., Sabia, J.J., 2015. When War Comes Home: The Effect of Combat Service on Domestic Violence. Review of Economics and Statistics 98, 209-225. 
Christelis, D., Georgarakos, D., 2013. Financial Decisions under the Shadow of Terrorism. Goethe University Frankfurt, Frankfurt.

Christianson, S.-Å., Hübinette, B., 1993. Hands Up! A Study of Witnesses' Emotional Reactions and Memories Associated with Bank Robberies. Applied Cognitive Psychology 7, 365-379.

Cohn, A., Engelmann, J., Fehr, E., Maréchal, M.A., 2015. Evidence for Countercyclical Risk Aversion: An Experiment with Financial Professionals. American Economic Review 105, 860-85.

Cortés, K., Duchin, R., Sosyura, D., 2016. Clouded Judgment: The Role of Sentiment in Credit Origination. Journal of Financial Economics 121, 392-413.

Danziger, S., Lev, J., Avnaim-Pesso, L., 2011. Extraneous Factors in Judicial Decisions. Proceedings of the National Academy of Sciences of the United States of America, $1-4$.

de Blasio, G., 2009. Distance and Internet Banking. In: Alessandrini P, Fratianni M \& Zazzaro A (eds.) The Changing Geography of Banking and Finance. Springer, New York NY, pp. 109-130.

De Jonghe, O., Dewachter, H., Mulier, K., Ongena, S., Schepens, G., 2019. Some Borrowers Are More Equal than Others: Bank Funding Shocks and Credit Reallocation. Review of Finance, Forthcoming.

De Jonghe, O., Dewachter, H., Ongena, S., 2016. Bank Capital (Requirements) and Credit Supply: Evidence from Pillar 2 Decisions. National Bank of Belgium, Brussels.

de Palma, A., Abdellaoui, M., Attanasi, G., Ben-Akiva, M., Erev, I., Fehr-Duda, H., Fok, D., Fox, C.R., Hertwig, R., Picard, N., Wakker, P.P., Walker, J.L., Weber, M., 2014. Beware of Black Swans: Taking Stock of the Description-Experience Gap in Decision under Uncertainty. Marketing Letters 25, 269-280.

Degryse, H., De Jonghe, O., Jakovljevic, S., Mulier, K., Schepens, G., 2019. Identifying Credit Supply Shocks with Bank-Firm Data: Methods and Applications. Journal of Financial Intermediation, Forthcoming.

Degryse, H., Kim, M., Ongena, S., 2009. Microeconometrics of Banking: Methods, Applications and Results. Oxford University Press.

Degryse, H., Liberti, J.M., Mosk, T., Ongena, S., 2011. Is Loan Officer Discretion Advised When Viewing Soft Information? CentER, Tilburg.

Degryse, H., Ongena, S., 2005. Distance, Lending Relationships, and Competition. Journal of Finance 60, 231-266.

Demiroglu, C., Ozbas, O., Silva, R.C., Ulu, M.F., 2017. Does Religion Affect Economic Decisions? Evidence from Ramadan Loans. Koc University, Istanbul.

Dessaint, O., Matray, A., 2017. Do Managers Overreact to Salient Risks? Evidence from Hurricane Strikes. Journal of Financial Economics 126, 97-121.

Dougal, C., Engelberg, J., Parsons, C.A., Van Wesep, E.D., 2015. Anchoring on Credit Spreads. Journal of Finance 70, 1039-1080.

Eckel, C.C., El-Gamal, M.A., Wilson, R.K., 2009. Risk Loving after the Storm: A Bayesian-Network study of Hurricane Katrina Evacuees. Journal of Economic Behavior and Organization 69, 110-124. 
Edgerton, J., 2012. Credit Supply and Business Investment During the Great Recession: Evidence from Public Records of Equipment Financing. Federal Reserve Board, Washington DC.

Edmans, A., GarcÍa, D., Norli, Ø., 2007. Sports Sentiment and Stock Returns. Journal of Finance 62, 1967-1998.

Fenton-O'Creevy, M., Soane, E., Nicholson, N., Willman, P., 2011. Thinking, Feeling and Deciding: The Influence of Emotions on the Decision Making and Performance of Traders. Journal of Organizational Behavior 32, 1044-1061.

Fenton-O'Creevy, M., Lins, J., Vohra, S., Richards, D., Davies, G., Schaaff, K., 2012. Emotion Regulation and Trader Expertise: Heart Rate Variability on the Trading Floor. Journal of Neuroscience, Psychology and Economics 5, 227-237.

Frijda, N.H., 1986. The Emotions. Cambridge University Press, Cambridge.

Garmaise, M.J., Moskowitz, T.J., 2005. Bank Mergers and Crime: The Real and Social Effects of Credit Market Competition. Journal of Finance 61, 495-538.

Gimeno, D., Benavides, F.G., Benach, J., Amick, B.C., 2004. Distribution of Sickness Absence in the European Union Countries. Occupational and Environmental Medicine 61, 867-869.

Giné, X., Garcia, N., Gómez-González, J., 2017. Financial Information in Colombia. World Bank, Washington DC.

Gross, J.J., 2002. Emotion Regulation: Affective, Cognitive, and Social Consequences. Psychophysiology 39, 281-291.

Guiso, L., Sapienza, P., Zingales, L., 2014. Time Varying Risk Aversion. University of Chicago, Chicago.

Hannan, T.H., 1982. Bank Robberies and Bank Security Precautions. Journal of Legal Studies 11, 83-92.

Harvey, A.C., 1976. Estimating Regression Models with Multiplicative Heteroscedasticity. Econometrica 44, 461-465.

Hatfield, E., Cacioppo, J.T., Rapson, R.L., 1993. Emotional Contagion. Current Directions in Psychological Science 2, 96-100.

Herpfer, C., 2018. The Role of Bankers in the U.S. Syndicated Loan Market. Emory's Goizueta Business School, Atlanta GA.

Herpfer, C., Schmidt, C., Mjøs, A., 2017. The Causal Impact of Distance on Bank Lending. Emory's Goizueta Business School, Atlanta.

Hertz, N., 2011. Women and Banks: Are Female Customers Facing Discrimination? Institute for Public Policy Research, London.

Hertzberg, A., Liberti, J.M., Paravisini, D., 2010. Information and Incentives Inside The Firm: Evidence From Loan Officer Rotation. Journal of Finance 65, 795-828.

Jiménez, G., Ongena, S., Peydró, J.-L., Saurina, J., 2012. Credit Supply and Monetary Policy: Identifying the Bank Balance-Sheet Channel with Loan Applications. American Economic Review 102, 2301-2326.

Johnston, D.A., 1978. Psychological Observations of Bank Robbery. American Psychiatric Association 135, 1377-1379.

Kamphuis, J.H., Emmelkamp, P.M.G., 1998. Crime-Related Trauma: Psychological Distress in Victims of Bankrobbery. Journal of Anxiety Disorders 12, 199-208. 
Kaplanski, G., Levy, H., 2010. Exploitable predictable Irrationality: The FIFA World Cup effect on the U.S. Stock Market. Journal of Financial and Quantitative Analysis 45, 535-553.

Karolyi, S.A., 2018. Personal Lending Relationships. Journal of Finance 73, 5-49.

Kessler, R.C., Sonnega, A., Bromet, E., Hughes, M., Nelson, C.B., 1996. Posttraumatic Stress Disorder in the National Comorbidity Survey. Archives of General Psychiatry 52, 1048-1060.

Khwaja, A.I., Mian, A., 2008. Tracing the Impact of Bank Liquidity Shocks: Evidence from an Emerging Market. American Economic Review 98, 1413-1442.

Kim, Y.-I., Lee, J., 2014. The Long-run Impact of a Traumatic Experience on Risk Aversion. Journal of Economic Behavior and Organization 108, 174-186.

Kleim, B., Ehlers, A., 2009. Evidence for a Curvilinear Relationship between Posttraumatic Growth and Posttrauma Depression and PTSD in Assault Survivors. Journal of Traumatic Stress 22, 45-52.

Kleim, B., Ehlers, A., Glucksman, E., 2007. Early Predictors of Chronic Post-Traumatic Stress Disorder in Assault Survivors. Psychological Medicine, 1457-1467.

Lamm Weisel, D., 2007. Bank Robbery. U.S. Department of Justice, Washington DC.

Leeman-Conley, M., 1990. After a Violent Robbery. Criminology Australia 1, 4-6.

Lehmann, E.E., Neuberger, D., 2001. Do Lending Relationships Matter? Evidence from Bank Survey Data in Germany. Journal of Economic Behavior and Organization 45, 339-359.

Lerner, J.S., Keltner, D., 2001. Fear, Anger, and Risk. Journal of Personality and Social Psychology 81, 146-159.

Leymann, H., 1988. Stress Reactions after Bank Robberies: Psychological and Psychosomatic Reaction Patterns. Work and Stress 2, 123-132.

Liberti, J.M., 2004. Initiative, Incentives and Soft Information: How Does Delegation Impact the Role of Bank Relationship Managers? Kellogg School of Management Northwestern, Chicago IL.

Liberti, J.M., Mian, A.R., 2009. Estimating the Effect of Hierarchies on Information Use. Review of Financial Studies 22, 4057-4090.

Lipshitz, R., Shulimovitz, N., 2007. Intuition and Emotion in Bank Loan Officers' Credit Decisions. Journal of Cognitive Engineering and Decision Making 1, 212-233.

Lo, A.W., Repin, D.V., 2002. The Psychophysiology of Real-Time Financial Risk Processing. Journal of Cognitive Neuroscience 14, 323-339.

Lo, A.W., Repin, D.V., Steenbarger, B.N., 2005. Fear and Greed in Financial Markets: A Clinical Study of Day Traders. American Economic Review 95, 352-359.

Loewenstein, G., 2000. Emotions in Economic Theory and Economic Behavior. American Economic Review Papers and Proceedings 90, 426-432.

Lowenstein, G., Lerner, J.S., 2003. The Role of Affect in Decision Making. In: Davidson RJ, Sherer KR \& Goldsmith HH (eds.) Handbook of Affective science. Oxford University Press, New York: NY, pp. 619-642.

Malmendier, U., Nagel, S., 2011. Depression Babies: Do Macroeconomic Experiences Affect Risk Taking? Quarterly Journal of Economics 126, 373-416.

Manove, M.A., Padilla, A.J., Pagano, M., 2001. Collateral versus Project Screening: A Model of Lazy Banks. RAND Journal of Economics 32, 726-744. 
Mastrobuoni, G., Rivers, D.A., 2019. Optimizing Criminal Behavior and the Disutility of Prison. Economic Journal, Fortcoming.

Miller-Burke, J., Attridge, M., Fass, P.M., 1999. Impact of Traumatic Events and Organizational Response: A Study of Bank Robberies. Journal of Occupational and Environmental Medicine 41, 73-83.

Morais, B., Peydró, J.-L., Roldan-Pena, J., Ruiz-Ortega, C., 2019. The International Bank Lending Channel of Monetary Policy Rates and QE: Credit Supply, Reach-forYield, and Real Effects. Journal of Finance 74, 55-90.

Mosk, T., 2013. Bargaining with a Bank. Tilburg University, Tilburg.

O'Flaherty, B., 2009. Why Have Robberies Become Less Frequent but More Violent? Journal of Law, Economics, and Organization 25, 518-534.

Ongena, S., Popov, A., 2016. Gender Bias and Credit Access. Journal of Money, Credit and Banking 48, 1691-1724.

Oswald, A.J., Proto, E., Sgroi, D., 2015. Happiness and Productivity. Journal of Labor Economics 33, 789-822.

Ozenne, T., 1974. The Economics of Bank Robbery. Journal of Legal Studies 19, 19-51.

Pérez-Olmos, I., Fernández-Piñeres, P.E., Rodado-Fuentes, S., 2005. Prevalencia del Trastorno por Estrés Postraumático por la Guerra, en niños de Cundinamarca, Colombia. Revista de Salud Pública 7, 268-280.

Petersen, M.A., Rajan, R.G., 1994. The Benefits of Lending Relationships: Evidence from Small Business Data. Journal of Finance 49, 3-37.

Petersen, M.A., Rajan, R.G., 2002. Does Distance Still Matter? The Information Revolution in Small Business Lending. Journal of Finance 57, 2533-2570.

Pool, V.K., Stoffman, N., Yonker, S.E., Zhang, H., 2019. Do Shocks to Personal Wealth Affect Risk Taking in Delegated Portfolios? Review of Financial Studies 32, $1457-$ 1493.

Pshisva, R., Suarez, G.A., 2010. "Captive Markets": The Impact of Kidnappings on Corporate Investment in Colombia". In: Di Tella R, Edwards S \& Schargrodsky E (eds.) The Economics of Crime: Lessons for and from Latin America. National Bureau of Economic Research - University of Chicago Press, Cambridge MA, pp. $63-97$.

Puri, M., Rocholl, J., Steffen, S., 2011. Rules versus Discretion in Bank Lending Decisions. ESMT, Berlin.

Putnam, L.L., Mumby, D.K., 1993. Organizations, Emotion and the Myth of Rationality. In: Fineman S (ed.) Emotion In Organization. Sage, London, pp. 36-57.

Qian, J., Strahan, P.E., 2007. How Law and Institutions Shape Financial Contracts: The Case of Bank Loans. Journal of Finance 62, 2803-2834.

Raghunathan, R., Tuan Pham, M., 1999. All Negative Moods Are Not Equal: Motivational Influences of Anxiety and Sadness on Decision Making. Organizational Behavior and Human Decision Processes 79, 56-77.

Rajan, R.G., Winton, A., 1995. Covenants and Collateral as Incentives to Monitor. Journal of Finance 50, 1113-1146.

Ravina, E., 2009. Love \& Loans: The Effect of Beauty and Personal Characteristics in Credit Markets. Columbia Business School, New York NY. 
Richards, A., Ospina, J., Barrera, M., Marmar, C.R., 2011. Posttraumatic Stress Disorder, Anxiety and Depression Symptoms, and Psychosocial Treatment Needs in Colombians Internally Displaced by Armed Conflict: A Mixed-Method Evaluation. Psychological Trauma Theory Research Practice and Policy 3, 384-393.

Samavati, H., 2006. Economics of Crime: Panel Data Analysis of Bank Robbery in the United States. Atlantic Economic Journal 34, 455-466.

Saunders, E.M., 1993. Stock Prices and Wall Street Weather. American Economic Review $83,1337-1345$.

Schlenger, W.E., Kulka, R.A., Fairbank, J.A., Hough, R.L., Kathleen Jordan, B., Marmar, C.R., Weiss, D.S., 1992. The Prevalence of Post-traumatic Stress Disorder in the Vietnam Generation: A Multimethod, Multisource Assessment of Psychiatric Disorder. Journal of Traumatic Stress 5, 333-363.

Taleb, N.N., 2007. The Black Swan: The Impact of the Highly Improbable. Random House, New York NY.

Trönnberg, C.-C., Hemlin, S., 2014. Lending Decision Making in Banks: A Critical Incident Study of Loan Officers. European Management Journal 32, 362-372.

Truman, J.L., Morgan, R.E., 2015. Criminal Victimization 2015. U.S. Department of Justice, Office of Justice Programs, Bureau of Justice Statistics, Washington DC.

Tversky, A., Kahneman, D., 1992. Advances in Prospect Theory: Cumulative Representation of Uncertainty. Journal of Risk and Uncertainty 5, 297-323.

Voors, M.J., Nillesen, E.E.M., Verwimp, P., Bulte, E.H., Lensink, R., Van Soest, D.P., 2012. Violent Conflict and Behavior: A Field Experiment in Burundi. American Economic Review 102, 941-964.

Wang, A.Y., Young, M., 2019. Terrorist Attacks and Investor Risk Preference: Evidence from Mutual Fund Flows. Journal of Financial Economics, Forthcoming.

White, M., McManus, F., Ehlers, A., 2008. An Investigation of Whether Patients with PostTraumatic Stress Disorder Overestimate the Probability and Cost of Future Negative Events. Journal of Anxiety Disorders 22, 1244-1254.

Yehuda, R., 2002. Post-Traumatic Stress Disorder. New England Journal of Medicine 346, 108-114. 


\section{DIAGRAM 1}

Diagram 1 Panel A

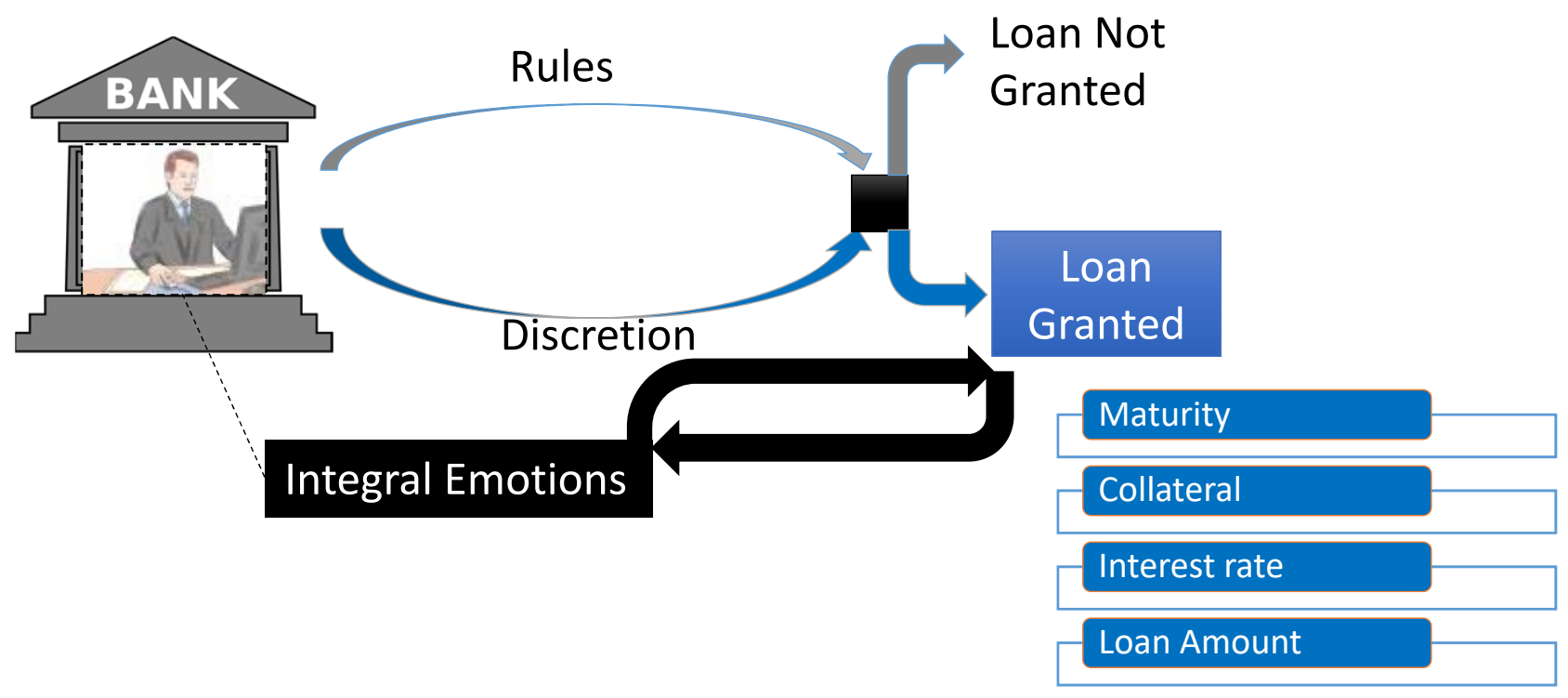




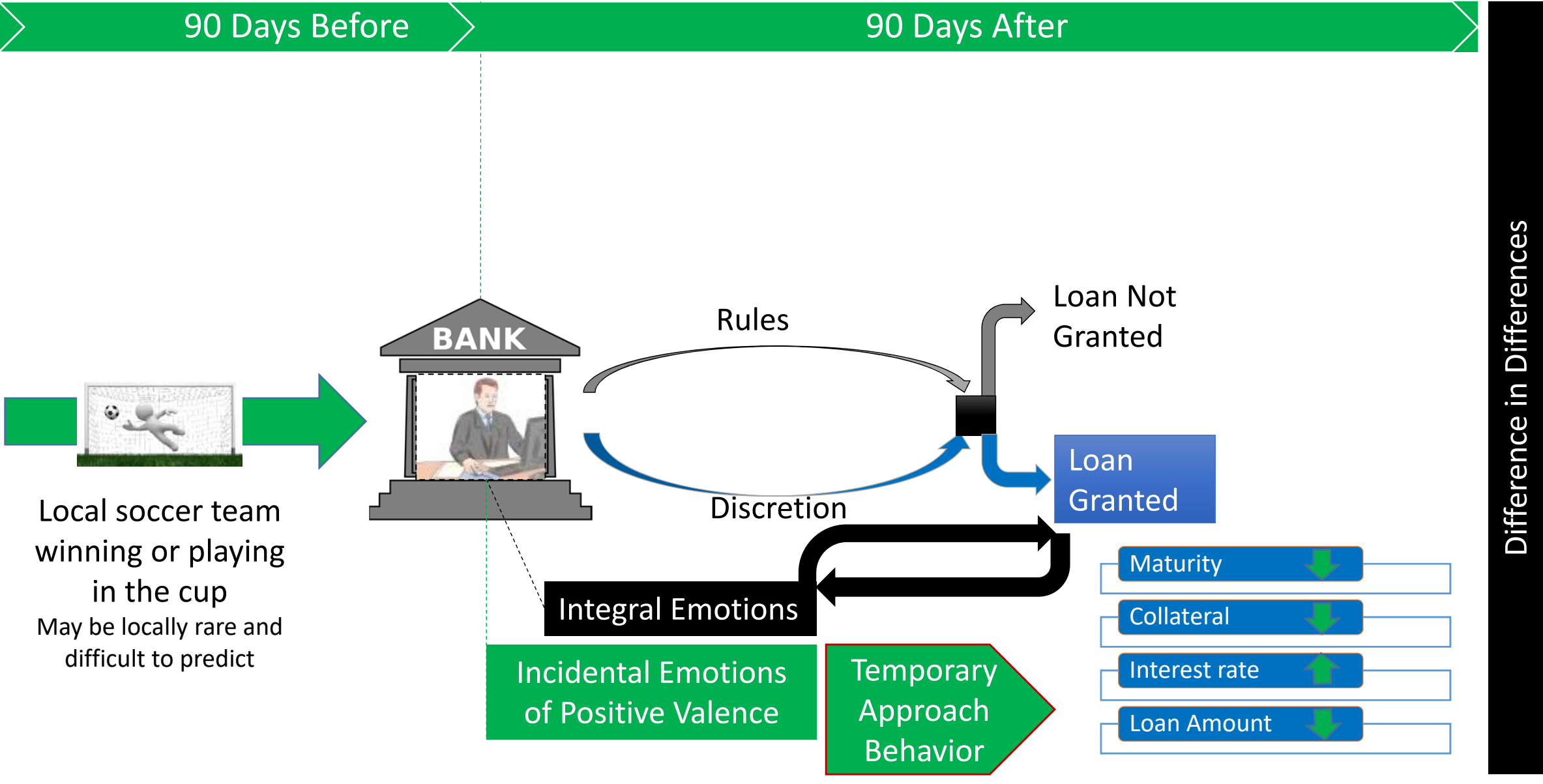

The diagram presents the loan officer following rules and using discretion whereby integral emotions may play a role in determining loan conditions (Panel A). When a robbery occurs incidental emotions of negative valence may lead to temporary avoidance behavior altering loan conditions in the indicated direction(Panel B), while a local soccer team win incidental emotions of positive valence may lead to temporary approach behavior altering loan conditions in the opposite direction (Panel C). Changes in loan terms are assessed with a difference in differences approach. 

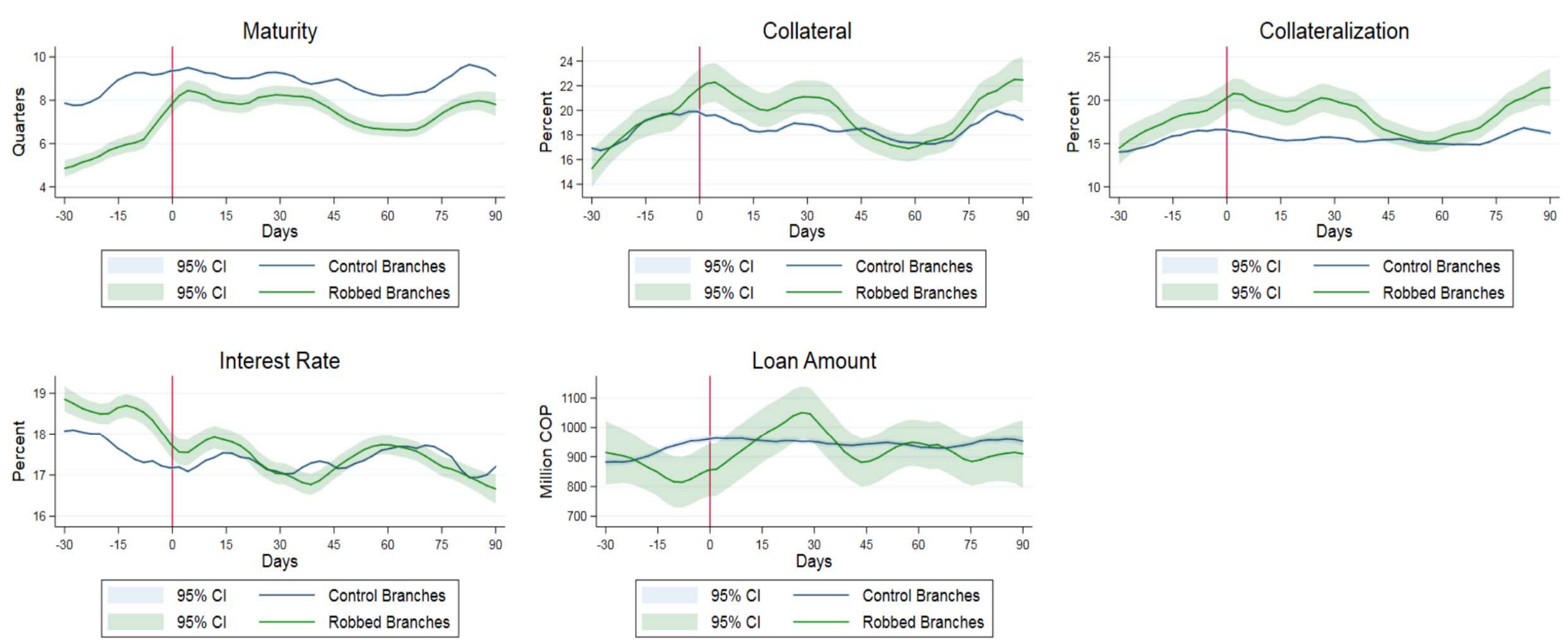

This figure presents the trend for each of the loan characteristics, by robbed branches and control branches. The vertical red lines represent the dates of the robberies. 

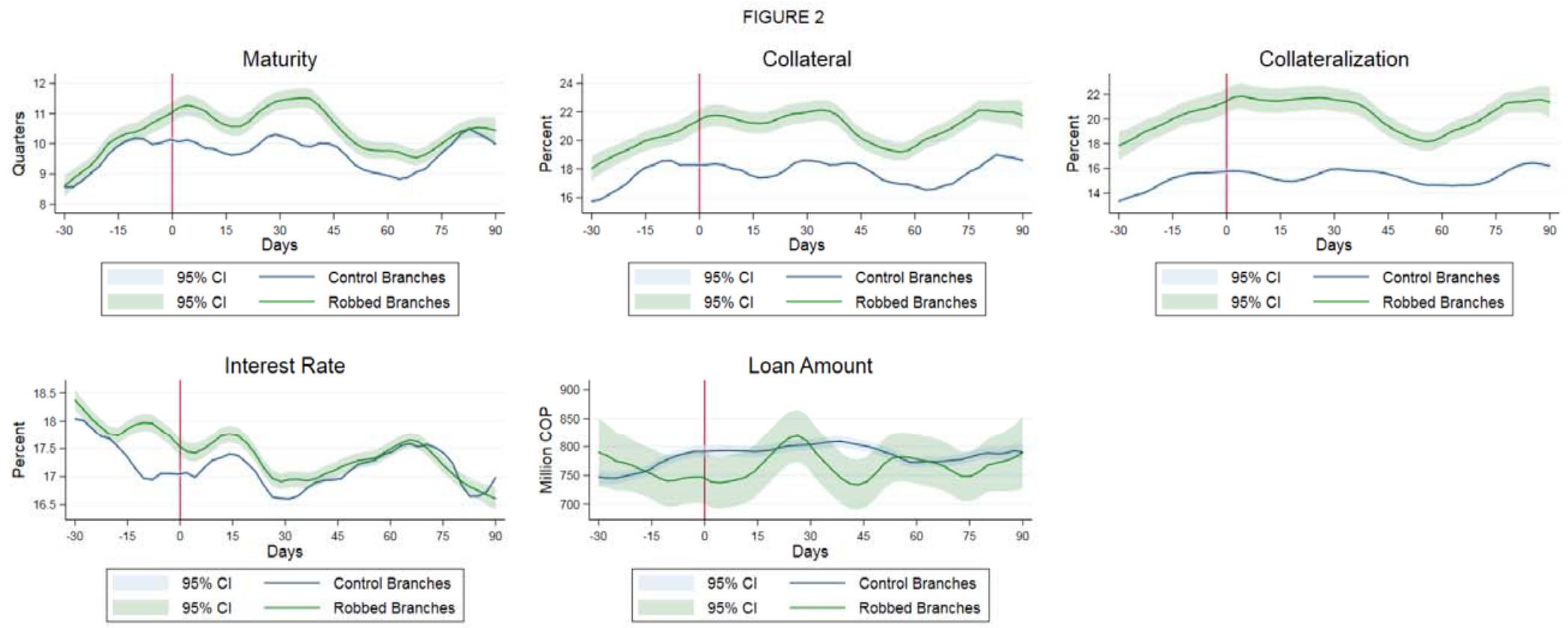

This figure presents the trend for each of the loan characteristics of new loans granted in robbed branches and those granted in control branches, after exactly matching loans on Length of Relationship, Main Bank, Small Firm, Age as Borrower, Number of Relationships, Default (t-1), and Firm Rating. The vertical red lines represent the dates of the robberies. 


\section{FIGURE 3}

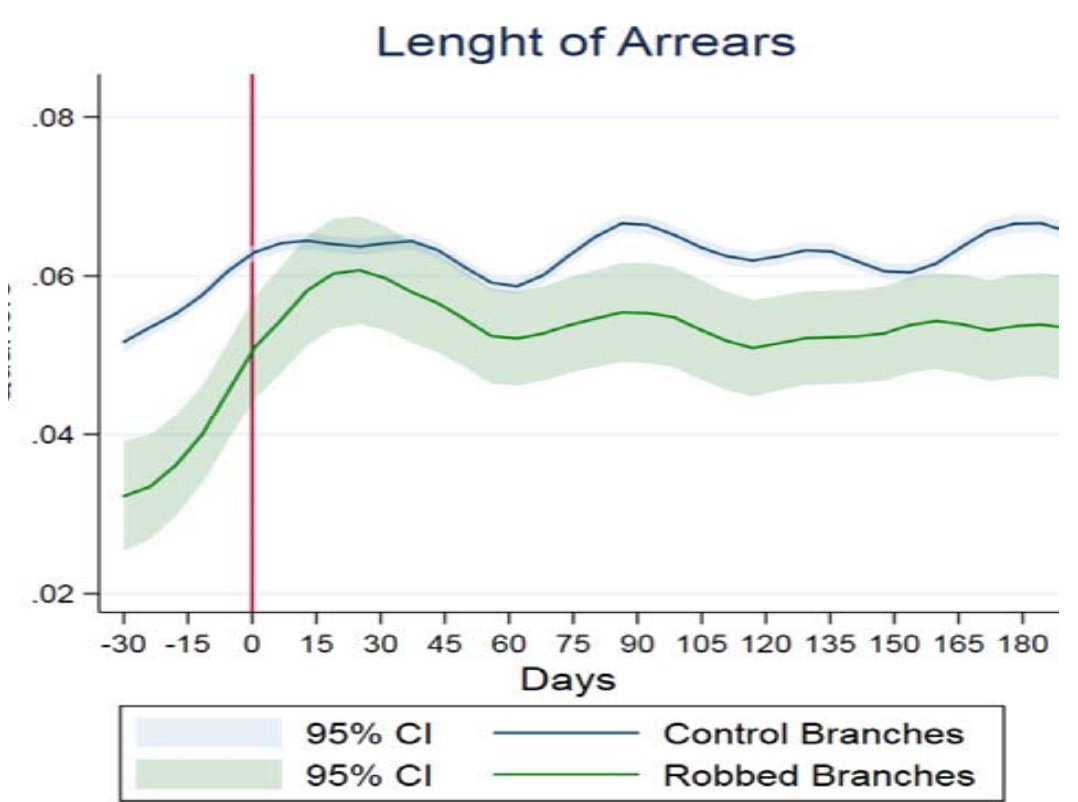

This figure presents the performance of the new loans granted in robbed branches and of those granted in control branches. The vertical red lines represent the dates of the robberies. 
FIGURE 4
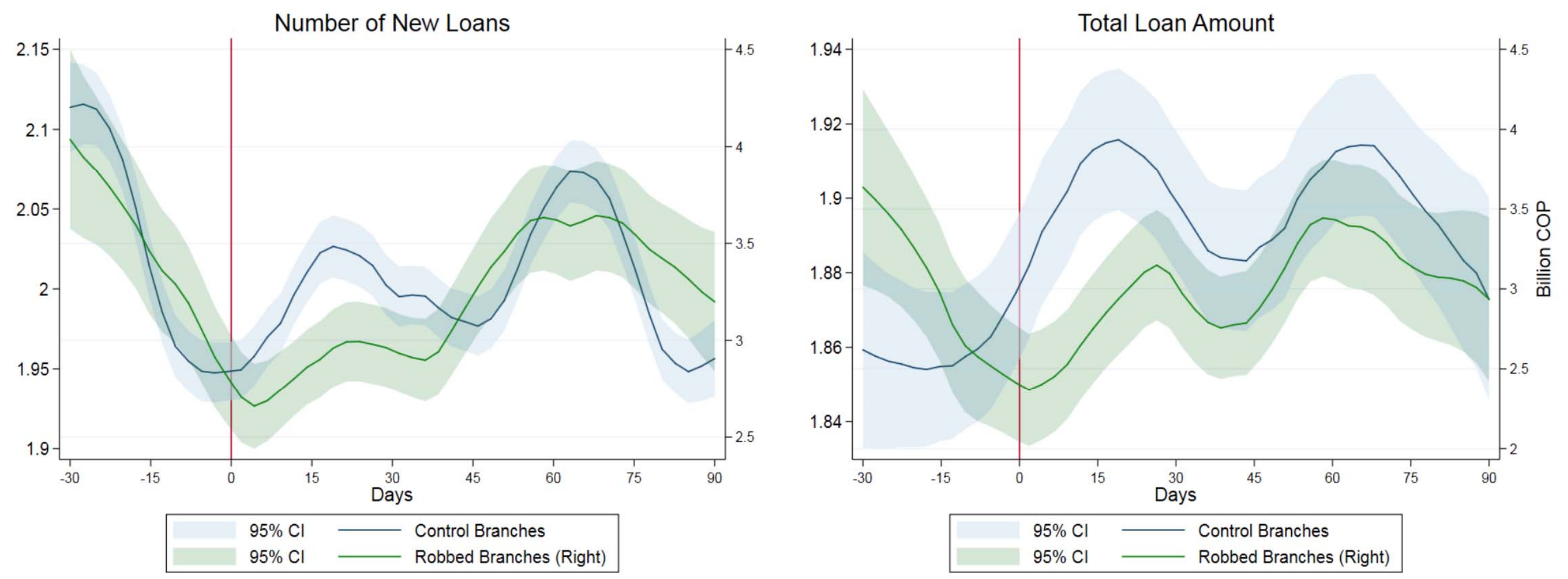

This figure presents the trend for the number of new loans and the total loan amount at the branch level, by robbed branches and control branches. The vertical red lines represent the dates of the robberies. 


\begin{tabular}{|c|c|c|c|}
\hline Variable & Mean & Median & $\mathrm{SD}$ \\
\hline \multicolumn{4}{|l|}{$\begin{array}{l}\text { Register of Robberies (National Police of Colombia) } \\
\text { Time Period: 2003:01-2011:12 }\end{array}$} \\
\hline \multicolumn{4}{|l|}{ Number of Robberies $=835$} \\
\hline Amount Stolen, in US Dollars & 37,000 & 6,300 & 97,600 \\
\hline Amount Stolen / Robbed Branch Deposits, in percent & 0.97 & 0.01 & 4.61 \\
\hline \multicolumn{4}{|l|}{$\begin{array}{l}\text { Credit Registery (Financial Superintendence of Colombia) } \\
\text { Time Period: 1998:12-2010:12 }\end{array}$} \\
\hline \multicolumn{4}{|l|}{ Number of Originated Loans $=659,053$} \\
\hline Loan Amount, in US Dollars & 357,778 & 44,444 & $2,011,111$ \\
\hline \multicolumn{4}{|l|}{$\begin{array}{l}\text { Sample: Match of Registry of Robberies with Credit Registry } \\
\text { Time Period: 2003:01-2010:12 }\end{array}$} \\
\hline \multicolumn{4}{|l|}{ Number of Robberies $=389$} \\
\hline Amount Stolen, in US dollars & 19,980 & 4,995 & 54,718 \\
\hline Amount Stolen / Robbed Branch Deposits, in percent & 0.02 & 0.00 & 0.12 \\
\hline \multicolumn{4}{|l|}{ Number of Originated Loans $=21,579$} \\
\hline Loan Amount, in US Dollars & 491,619 & 58,189 & $1,631,868$ \\
\hline \multicolumn{4}{|l|}{ Number of Branches in the Rest of the Country $=1,649$} \\
\hline \multicolumn{4}{|l|}{ Number of Originated Loans $=242,577$} \\
\hline Loan Amount, in US Dollars & 465,623 & 72,036 & $1,548,286$ \\
\hline
\end{tabular}

This table presents the registries underlying the sample used in the analysis, and the mean, median, and standard deviation (SD) statistics of selected variables. COP: Colombian peso. In June 2011, 1,800 COP =1 US dollar; 1 Million COP = 555 US dollars. 
TABLE 2.-SUMMARY STATISTICS FOR DEPENDENT AND INDEPENDENT VARIABLES

\begin{tabular}{|c|c|c|c|c|c|c|c|}
\hline Variable & Description & Unit & Mean & Median & $\mathrm{SD}$ & Min & Max \\
\hline \multicolumn{8}{|c|}{ Dependent Variables: Loan Characteristics } \\
\hline Maturity & Loan maturity & Months & 8.7 & 3.0 & 16.5 & 0.0 & 341.0 \\
\hline Collateral & $=100$ if loan is collateralized, $=0$ otherwise & $100 / 0$ & 18.4 & 0.0 & 38.7 & 0.0 & 100.0 \\
\hline Collateralization & Collateral / Loan Amount & $\%$ & 15.4 & 0.0 & 49.3 & 0.0 & 998.4 \\
\hline Interest Rate & Interest rate on the loan & $\%$ & 17.5 & 16.2 & 7.8 & 0.4 & 38.0 \\
\hline Loan Amount & Loan size & Million COP & 927.9 & 150.0 & $2,932.9$ & 0.0 & $50,000.0$ \\
\hline \multicolumn{8}{|l|}{ Independent Variables } \\
\hline \multicolumn{8}{|l|}{ Robbery Characteristics } \\
\hline Branch Robbed & $=1$ if the bank branch is robbed, $=0$ otherwise & $1 / 0$ & 0.0 & 0.0 & 0.1 & 0.0 & 1.0 \\
\hline After & $=1$ in the period after the robbery, $=0$ otherwise & $1 / 0$ & 0.5 & 1.0 & 0.5 & 0.0 & 1.0 \\
\hline $\ln$ (Days After the Robbery) & The logarithm of the number of days after the robbery & - & 0.0 & 0.0 & 0.3 & 0.0 & 4.5 \\
\hline Firearm & $=1$ if a firearm is present during the robbery, $=0$ otherwise & $1 / 0$ & 0.9 & 1.0 & 0.2 & 0.0 & 1.0 \\
\hline Robbed Amount over Deposits & The ratio of the amount stolen and the deposits at the bank branch & $\%$ & 0.03 & 0.00 & 0.13 & 0.00 & 1.49 \\
\hline \multicolumn{8}{|l|}{ Relationship Characteristics } \\
\hline Length of Relationship & Length of the bank-firm relationship & Quarters & 14.2 & 12.0 & 10.3 & 1.0 & 49.0 \\
\hline Main Bank & $=1$ if loan granted by primary bank, $=0$ otherwise & $1 / 0$ & 0.2 & 0.0 & 0.4 & 0.0 & 1.0 \\
\hline \multicolumn{8}{|l|}{ Firm Characteristics } \\
\hline Small Firm & $=1$ if small firm, $=0$ otherwise & $1 / 0$ & 0.3 & 0.0 & 0.5 & 0.0 & 1.0 \\
\hline Age as Borrower & Number of quarters since the firm obtained its first loan listed in the credit register & Quarters & 26.8 & 27.0 & 10.7 & 1.0 & 49.0 \\
\hline Number of Relationships & Number of lenders to the firm & - & 6.0 & 5.0 & 3.5 & 1.0 & 27.0 \\
\hline Default (t-1) & $=1$ if firm defaulted on a loan during the previous year, $=0$ otherwise & $1 / 0$ & 0.1 & 0.0 & 0.3 & 0.0 & 1.0 \\
\hline Firm Rating & Weighted quality of the loans of the firm (1 lowest, 5 highest $)$ & $1-5$ & 4.9 & 5.0 & 0.3 & 1.0 & 5.0 \\
\hline
\end{tabular}

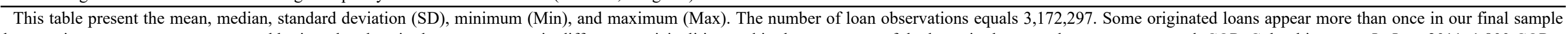

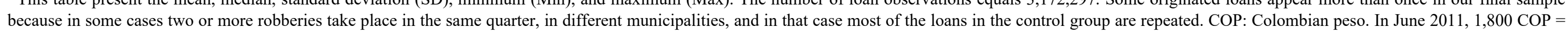
1 US dollar; 1 Million COP $=555$ US dollars. 
TABLE 3.-DIFFERENCES IN MEANS OF LOAN, RELATIONSHIP, AND FIRM CHARACTERISTICS BETWEEN ROBBED BRANCHES AND BRANCHES IN THE REST OF THE COUNTRY

\begin{tabular}{|c|c|c|c|c|c|c|c|}
\hline \multirow[b]{2}{*}{ Variable } & \multicolumn{2}{|c|}{ Robbed Branches } & \multicolumn{2}{|c|}{ Branches in the Rest of the Country } & \multicolumn{2}{|c|}{ Differences } & \multirow[t]{2}{*}{ Difference in Differences } \\
\hline & $\begin{array}{c}\text { Before Bank } \\
\text { Robbery }\end{array}$ & $\begin{array}{c}\text { After Bank } \\
\text { Robbery }\end{array}$ & $\begin{array}{c}\text { Before Bank } \\
\text { Robbery }\end{array}$ & $\begin{array}{c}\text { After Bank } \\
\text { Robbery }\end{array}$ & Before Bank Robbery & After Bank Robbery & \\
\hline \multicolumn{8}{|c|}{ Dependent Variables: Loan Characteristics } \\
\hline Maturity & 6.3 & 7.6 & 8.5 & 8.9 & $-2.2 * * *$ & $-1.3 * * *$ & $0.8 * * *$ \\
\hline Collateral & 18.7 & 19.7 & 18.3 & 18.5 & 0.5 & $1.2 * * *$ & $0.7 *$ \\
\hline Collateralization & 17.8 & 18.2 & 15.1 & 15.6 & $2.7 * * *$ & $2.7 * * *$ & -0.1 \\
\hline Interest Rate & 18.1 & 17.3 & 17.6 & 17.3 & $0.5 * * *$ & 0.0 & $-0.5 * * *$ \\
\hline Ln(Loan Amount) & 4.6 & 4.7 & 4.8 & 4.9 & $-0.2 * * *$ & $-0.1 * * *$ & 0.1 \\
\hline \multicolumn{8}{|l|}{ Independent Variables } \\
\hline \multicolumn{8}{|c|}{ Relationship Characteristics } \\
\hline Length of Relationship & 15.3 & 16.3 & 13.9 & 14.5 & $1.4 * * *$ & $1.8 * * *$ & $0.3 * * *$ \\
\hline Main Bank & 0.4 & 0.4 & 0.2 & 0.2 & $0.1 * * *$ & $0.1 * * *$ & $0.0 *$ \\
\hline \multicolumn{8}{|l|}{ Firm Characteristics } \\
\hline Small Firm & 0.4 & 0.4 & 0.3 & 0.3 & $0.1 * * *$ & $0.1 * * *$ & 0.0 \\
\hline Age as Borrower & 24.6 & 25.5 & 26.4 & 27.3 & $-1.8 * * *$ & $-1.8 * * *$ & 0.0 \\
\hline Number of Relationships & 5.0 & 5.0 & 6.0 & 6.1 & $-1.0 * * *$ & $-1.1 * * *$ & 0.0 \\
\hline Default (t-1) & 0.1 & 0.1 & 0.1 & 0.1 & $0.0 *$ & 0.0 & 0.0 \\
\hline Firm Rating & 4.9 & 4.9 & 4.9 & 4.9 & $0.0 * * *$ & $0.0^{* * *}$ & 0.0 \\
\hline
\end{tabular}




\begin{tabular}{|c|c|c|c|c|c|c|c|c|c|c|c|c|c|c|c|c|c|c|c|c|c|c|c|c|c|}
\hline $\begin{array}{r}\text { Models } \\
\text { Dependent Variables }\end{array}$ & $\overline{\mathrm{II}}$ & $\begin{array}{ll}\text { II } \\
\end{array}$ & $\begin{array}{c}\text { III } \\
\text { Maturity }\end{array}$ & IV IV & $\mathrm{V}$ & I & II & $\begin{array}{c}\text { III } \\
\text { Collateral }\end{array}$ & al $\quad$ IV & $\overline{\mathrm{V}}$ & II & $\begin{array}{l}\text { II } \\
\text { Coll }\end{array}$ & $\begin{array}{c}\text { III } \\
\text { Illateralizat }\end{array}$ & $\begin{array}{c}\text { IV } \\
\text { ation }\end{array}$ & $\overline{\mathrm{V}}$ & II & & $\begin{array}{c}\text { III } \\
\text { Interest Rat }\end{array}$ & Rate & $\overline{\mathrm{V}}$ & II & & $\begin{array}{c}\text { III } \\
\text { oan Amoul }\end{array}$ & sunt IV & $\overline{\mathrm{V}}$ \\
\hline \multicolumn{26}{|l|}{ Panel A. MAIN SPECIFICATIONS } \\
\hline Branch Robbed * After & $\begin{array}{r}0.74^{* * *} \\
(0.16)\end{array}$ & $\begin{array}{c}* 3.26 * * * \\
(0.81)\end{array}$ & $\begin{array}{c}1.70 \\
(3.66)\end{array}$ & $\begin{array}{r}3.18^{* * *} \\
(0.81)\end{array}$ & * $\begin{array}{c}1.33 \\
(3.78)\end{array}$ & $\begin{array}{c}0.42 \\
(0.28)\end{array}$ & $\begin{array}{c}3.35 \\
(2.80)\end{array}$ & $\begin{array}{l}-23.55^{* * *} \\
(8.43)\end{array}$ & $\begin{array}{c}3.38 \\
(2.84)\end{array}$ & $\begin{array}{l}-23.58 * * * \\
(8.92)\end{array}$ & $\begin{array}{l}*-0.35 \\
(0.36)\end{array}$ & $\begin{array}{l}3.91 * * \\
(1.88)\end{array}$ & $\begin{array}{c}\cdot 14.18^{* * *} \\
(4.61)\end{array}$ & 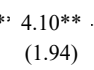 & $\begin{array}{l}13.18^{* * *}- \\
(4.64)\end{array}$ & $\begin{aligned} *-0.341 * * \\
(0.080)\end{aligned}$ & $\begin{array}{l}* 0.310 \\
(0.816)\end{array}$ & $\begin{array}{c}2.645 \\
(2.717)\end{array}$ & $\begin{array}{l}-0.304 \\
(0.827)\end{array}$ & $\begin{array}{c}2.711 \\
(2.735)\end{array}$ & $\begin{array}{l}34.34^{* *} \\
(14.10)\end{array}$ & $\begin{array}{l}\text { * } 39.10 \\
(70.95)\end{array}$ & $\begin{array}{c}-32.52 \\
(213.41)\end{array}$ & $\begin{array}{l}51.90 \\
(69.56)\end{array}$ & $\begin{array}{c}50.81 \\
(219.72)\end{array}$ \\
\hline Branch Robbed * After * $\ln$ (Days After the Robbery) & & $\begin{array}{c}-0.69^{* * * *} \\
(0.22)\end{array}$ & $\begin{array}{r}*-0.13 \\
(1.16)\end{array}$ & $\begin{array}{r}-0.67 * * \\
(0.22)\end{array}$ & $\begin{array}{l}-0.04 \\
(1.19)\end{array}$ & & $\begin{array}{l}-0.81 \\
(0.79)\end{array}$ & $\begin{array}{l}6.10^{* *} \\
(2.88)\end{array}$ & $\begin{array}{l}-0.82 \\
(0.80)\end{array}$ & $\begin{array}{l}6.09 * * \\
(2.98)\end{array}$ & & $\begin{array}{c}-1.17^{* *} \\
(0.53)\end{array}$ & $\begin{array}{l}3.55^{* *} \\
(1.80)\end{array}$ & $\begin{array}{c}-1.22 * * \\
(0.55)\end{array}$ & $\begin{array}{l}3.31^{*} \\
(1.80)\end{array}$ & & $\begin{array}{l}-0.009 \\
(0.228)\end{array}$ & $\begin{array}{c}-0.722 \\
(0.764)\end{array}$ & $\begin{array}{l}-0.013 \\
(0.230)\end{array}$ & $\begin{array}{r}-0.749 \\
(0.775)\end{array}$ & & $\begin{array}{c}-1.31 \\
(18.17)\end{array}$ & $\begin{array}{c}11.96 \\
(71.04)\end{array}$ & $\begin{array}{c}-4.32 \\
(17.89)\end{array}$ & $\begin{array}{l}-8.88 \\
(74.13)\end{array}$ \\
\hline Branch Robbed * After * Firearm & & & $\begin{array}{c}1.58 \\
(3.85)\end{array}$ & & $\begin{array}{c}1.88 \\
(3.97)\end{array}$ & & & $\begin{array}{c}27.37 * * * \\
(9.41)\end{array}$ & & $\begin{array}{l}27.39 * * * \\
(9.75)\end{array}$ & & & $\begin{array}{c}18.40^{* * * *} \\
(5.40)\end{array}$ & & $\begin{array}{c}17.56 * * * \\
(5.33)\end{array}$ & & & $\begin{array}{l}-3.008 \\
(2.971)\end{array}$ & & $\begin{array}{r}-3.063 \\
(2.974)\end{array}$ & & & $\begin{array}{c}73.01 \\
(236.71)\end{array}$ & & $\begin{array}{c}1.22 \\
(244.77)\end{array}$ \\
\hline Branch Robbed * After * $\ln ($ Days After the Robbery $) *$ Firearm & & & $\begin{array}{l}-0.57 \\
(1.21)\end{array}$ & & $\begin{array}{l}-0.64 \\
(1.24)\end{array}$ & & & $\begin{array}{l}-7.02^{* *} \\
(3.12)\end{array}$ & & $\begin{array}{c}-7.01 * * \\
(3.19)\end{array}$ & & & $\begin{array}{c}-4.80 * * \\
(1.92)\end{array}$ & & $\begin{array}{c}-4.60^{* *} \\
(1.91)\end{array}$ & & & $\begin{array}{l}0.725 \\
(0.836)\end{array}$ & & $\begin{array}{c}0.748 \\
(0.843)\end{array}$ & & & $\begin{array}{l}-13.51 \\
(72.78)\end{array}$ & & $\begin{array}{c}4.61 \\
(76.22)\end{array}$ \\
\hline Branch Robbed * After * Robbed Amount over Deposits & & & & $\begin{array}{c}0.02 \\
(0.01)\end{array}$ & $\begin{array}{c}0.02 \\
(0.01)\end{array}$ & & & & $\begin{array}{l}-0.01 \\
(0.05)\end{array}$ & $\begin{array}{c}0.00 \\
(0.05)\end{array}$ & & & & $\begin{array}{r}-0.05 \\
(0.04)\end{array}$ & $\begin{array}{l}-0.04 \\
(0.04)\end{array}$ & & & & $\begin{array}{l}-0.002 \\
(0.010)\end{array}$ & $\begin{array}{r}-0.003 \\
(0.010)\end{array}$ & & & & $\begin{array}{l}-3.11 * * * \\
(0.90)\end{array}$ & $\begin{array}{l}* *-3.10^{* * *} \\
(0.86)\end{array}$ \\
\hline Branch Robbed * After * $\ln$ (Days After the Robbery) * Robbed Amount over Deposits & & & & $\begin{array}{l}-0.01^{*} \\
(0.00)\end{array}$ & $\begin{array}{l}-0.01^{*} \\
(0.00)\end{array}$ & & & & $\begin{array}{c}0.00 \\
(0.01)\end{array}$ & $\begin{array}{l}-0.00 \\
(0.01)\end{array}$ & & & & $\begin{array}{c}0.01 \\
(0.01)\end{array}$ & $\begin{array}{c}0.01 \\
(0.01)\end{array}$ & & & & $\begin{array}{c}0.001 \\
(0.002)\end{array}$ & $\begin{array}{l}0.001 \\
(0.002)\end{array}$ & & & & $\begin{array}{c}0.74 * * * \\
(0.24)\end{array}$ & $\begin{array}{c}* 0.74 * * * \\
(0.23)\end{array}$ \\
\hline Branch-Event Fixed Effects $(150,699)$ & Yes & Yes & Yes & Yes & Yes & Yes & Yes & Yes & Yes & Yes & Yes & Yes & Yes & Yes & Yes & Yes & Yes & Yes & Yes & Yes & Yes & Yes & Yes & Yes & Yes \\
\hline After-Event Fixed Effects (389) & Yes & Yes & Yes & Yes & Yes & Yes & Yes & Yes & Yes & Yes & Yes & Yes & Yes & Yes & Yes & Yes & Yes & Yes & Yes & Yes & Yes & Yes & Yes & Yes & Yes \\
\hline Industry Fixed Effects (17) & Yes & Yes & Yes & Yes & Yes & Yes & Yes & Yes & Yes & Yes & Yes & Yes & Yes & Yes & Yes & Yes & Yes & Yes & Yes & Yes & Yes & Yes & Yes & Yes & Yes \\
\hline Relationship and Firm Characteristics & Yes & Yes & Yes & Yes & Yes & Yes & Yes & Yes & Yes & Yes & Yes & Yes & Yes & Yes & Yes & Yes & Yes & Yes & Yes & Yes & Yes & Yes & Yes & Yes & Yes \\
\hline Adjusted R-squared & 0.10 & 0.10 & 0.10 & 0.11 & 0.11 & 0.10 & 0.10 & 0.10 & 0.10 & 0.10 & 0.08 & 0.08 & 0.08 & 0.08 & 0.08 & 0.41 & 0.41 & 0.41 & 0.41 & 0.41 & 0.11 & 0.11 & 0.11 & 0.11 & 0.11 \\
\hline Change in Dependent Variable After a Bank Robbery & $0.7 \mathrm{mth}$. & is $3.3 \mathrm{mths}$ & $\mathrm{s} 1.7 \mathrm{mths}$ & $153.2 \mathrm{mths}$ & $\mathrm{s} 1.3 \mathrm{mths}$ & $0.4 \%$ & $3.4 \%$ & $-23.6 \%$ & $3.4 \%$ & $-23.6 \%$ & $-0.4 \%$ & $3.9 \%$ & $-14.2 \%$ & $4.1 \%$ & $-13.2 \%$ & $-0.3 \%$ & $-0.3 \%$ & $2.7 \%$ & $-0.3 \%$ & $2.8 \%$ & $34.3 \mathrm{M}$ & $39.1 \mathrm{M}$ & $-32.5 \mathrm{M}$ & $450.9 \mathrm{M}$ & $50.8 \mathrm{M}$ \\
\hline Change in Dependent Variable After a Bank Robbery as a Percentage of Its Mean & $8.5 \%$ & $37.5 \%$ & $19.5 \%$ & $36.6 \%$ & $15.3 \%$ & $2.2 \%$ & $18.5 \%$ & $-128.3 \%$ & $18.5 \%$ & $6-128.3 \%$ & $-2.3 \%$ & \% $25.4 \%$ & $6-92.1 \%$ & $26.6 \%$ & $-85.6 \%$ & $-2.0 \%$ & $-1.7 \%$ & $15.8 \%$ & $-1.7 \%$ & $16.2 \%$ & $3.7 \%$ & $4.2 \%$ & $-3.5 \%$ & $5.6 \%$ & $5.5 \%$ \\
\hline Half-Life of the Change in Dependent Variable After a Bank Robbery & & 10 days $>$ & $>>90$ days & ys 10 days & $>90$ days & & 8 days & 7 days & 8 days & 7 days & & 5 days & 7 days & 5 days & 7 days & & $>90$ days & o days & $>90$ days & s 6 days & & $>90$ days & s 4 days & 456 day & ys 17 days \\
\hline Additional Change in Dependent Variable After a & & & $1.6 \mathrm{mths}$ & & 1.9 mths & & & $27.4 \%$ & & $27.4 \%$ & & & $18.4 \%$ & & $17.6 \%$ & & & $-3.0 \%$ & & $-3.1 \%$ & & & $73 \mathrm{M}$ COP & & $1.2 \mathrm{M} \mathrm{COl}$ \\
\hline Half-Life of the Change in Dependent Variable After a Bank Robbery with Firearm & & & 4 days & & 4 days & & & 7 days & & 7 days & & & 7 days & & 7 days & & & 8 days & & 8 days & & & 15 days & & $>90$ days \\
\hline Additional Effect of a 1 St. Dev. more on Robbed Amount over Deposits & & & & $0.0 \mathrm{mths}$ & s 0.0 mths & & & & $0.0 \%$ & $0.0 \%$ & & & & $-0.1 \%$ & $0.0 \%$ & & & & $-0.0 \%$ & $0.0 \%$ & & & & . & $\underline{1}-\underline{-3} .1 \mathrm{M}$ \\
\hline \multicolumn{26}{|l|}{ Panel B. INCLUDING BUSINESS-YEAR:QUARTER FIXED EFFECTS } \\
\hline Branch Robbed * After & $\begin{array}{l}0.365 * * \\
(0.144)\end{array}$ & $\begin{array}{l}* 7.913 * * * \\
\quad(0.874)\end{array}$ & $\begin{array}{l}* 5.981 * * \\
(2.472)\end{array}$ & $\begin{array}{l}* 7.885 * * \\
(0.867)\end{array}$ & $\begin{array}{l}* 5.860^{* *} \\
(2.510)\end{array}$ & $\begin{array}{c}-0.49 \\
(0.31)\end{array}$ & $\begin{array}{c}11.65 * * * \\
(2.76)\end{array}$ & $\begin{array}{c}*-12.67 * * 1 \\
(6.21)\end{array}$ & $\begin{array}{c}11.69 * * * \\
(2.79)\end{array}$ & $\begin{array}{c}-12.55^{*} \\
(6.79)\end{array}$ & $\begin{array}{r}-1.14^{* * *} \\
(0.41)\end{array}$ & $\begin{array}{l}* * 11.20 * * * \\
)(1.51)\end{array}$ & $\begin{array}{ll}* * & -1.77 \\
& (5.20)\end{array}$ & $\begin{array}{c}11.38^{* * *} \\
(1.53)\end{array}$ & $\begin{array}{r}-0.64 \\
(5.42)\end{array}$ & $\begin{array}{c}-0.093 \\
(0.078)\end{array}$ & $\begin{array}{l}3.2 .415^{* * *}= \\
(0.701)\end{array}$ & $\begin{array}{l}1.236 \\
(2.006)\end{array}$ & $\begin{array}{l}2.422^{* * *} \\
(0.713)\end{array}$ & $\begin{array}{l}1.261 \\
(1.994)\end{array}$ & $\begin{array}{l}31.12 * \\
(16.49)\end{array}$ & $\begin{array}{l}116.09^{*} \\
(60.54)\end{array}$ & $\begin{array}{c}90.80 \\
(141.15)\end{array}$ & ) $122.04 *$ & $\begin{array}{l}\text { I* } 106.40 \\
\text { ) }(153.65)\end{array}$ \\
\hline Branch Robbed * After * $\ln ($ Days After the Robbery) & & $2.077 * * 3$ & $-1.384 * *$ & $* 2.071 * *$ & $-1.375^{* *}$ & & $-3.34 * * *$ & * $2.77-$ & $-3.36 * * *$ & * 2.68 & & $-3.40^{* * *}$ & * 0.06 & $-3.45 * * *$ & $* \begin{array}{ll}-0.27 \\
*\end{array}$ & & $0.639^{* * *}$ & $=-0.249$ & $0.640^{* * *}$ & $\begin{array}{r}-0.255 \\
0.566\end{array}$ & & $\begin{array}{r}-23.38 \\
(17.74\end{array}$ & -46.97 & $\begin{array}{l}-24.79 \\
(18.35)\end{array}$ & $\begin{array}{l}-51.68 \\
9\end{array}$ \\
\hline Branch Robbed * After * Firearm & & & $\begin{array}{c}1.961 \\
(2.430)\end{array}$ & & $\begin{array}{c}2.053 \\
(2.484)\end{array}$ & & & $\begin{array}{c}24.76^{* * *} \\
(7.13)\end{array}$ & & $\begin{array}{c}24.62^{* * * *} \\
(7.53)\end{array}$ & & & $\begin{array}{c}(1.20) \\
(5.35)\end{array}$ & & $\begin{array}{c}(1.61) \\
12.21 * * \\
(5.52)\end{array}$ & & & $\begin{array}{l}-3.716^{*} \\
(2.184)\end{array}$ & & $\begin{array}{l}(0.566) \\
-3.742^{*} \\
(2.161)\end{array}$ & & (17.74) & $\begin{array}{c}(41.91) \\
26.54 \\
(15576\end{array}$ & (18.35) & 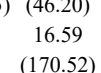 \\
\hline Branch Robbed * After * In(Days After the Robbery) * Firearm & & & $\begin{array}{l}-0.705 \\
(0.682)\end{array}$ & & $\begin{array}{c}-0.707 \\
(0.692)\end{array}$ & & & $\begin{array}{c}-6.22 * * * \\
(2.34)\end{array}$ & & $\begin{array}{c}-6.13^{* *} \\
(2.42)\end{array}$ & & & $\begin{array}{c}-3.51 * * \\
(1.60)\end{array}$ & & $\begin{array}{c}-3.22 * * \\
(1.62)\end{array}$ & & & $\begin{array}{c}0.904 \\
(0.609)\end{array}$ & & $\begin{array}{c}0.909 \\
(0.608)\end{array}$ & & & $\begin{array}{c}23.86 \\
(44.75)\end{array}$ & & $\begin{array}{c}27.21 \\
(48.09)\end{array}$ \\
\hline Branch Robbed * After * Robbed Amount over Deposits & & & & $\begin{array}{c}0.007 \\
(0.013)\end{array}$ & $\begin{array}{c}0.008 \\
(0.014)\end{array}$ & & & & $\begin{array}{c}-0.00 \\
(0.04)\end{array}$ & $\begin{array}{c}0.00 \\
(0.04)\end{array}$ & & & & $\begin{array}{c}-0.04 \\
(0.03)\end{array}$ & $\begin{array}{c}-0.04 \\
(0.03)\end{array}$ & & & & $\begin{array}{c}0.002 \\
(0.009)\end{array}$ & $\begin{array}{c}0.001 \\
(0.008)\end{array}$ & & & & $\begin{array}{c}-1.56 * * \\
(0.68)\end{array}$ & $\begin{array}{c}-1.53^{* *} \\
(0.70)\end{array}$ \\
\hline Branch Robbed * After * $\ln$ (Days After the Robbery) * Robbed Amount over Deposits & & & & $\begin{array}{c}-0.002 \\
(0.003)\end{array}$ & $\begin{array}{c}-0.002 \\
(0.003)\end{array}$ & & & & $\begin{array}{c}0.00 \\
(0.01)\end{array}$ & $\begin{array}{c}0.00 \\
(0.01)\end{array}$ & & & & $\begin{array}{c}0.01 \\
(0.01)\end{array}$ & $\begin{array}{c}0.01 \\
(0.01)\end{array}$ & & & & $\begin{array}{c}-0.000 \\
(0.002)\end{array}$ & $\begin{array}{l}-0.000 \\
(0.002)\end{array}$ & & & & $\begin{array}{l}0.37^{*} \\
(0.19)\end{array}$ & $\begin{array}{l}0.37^{*} \\
(0.20)\end{array}$ \\
\hline Branch-Event & Yes & Yes & Yes & Yes & Yes & Yes & Yes & Yes & Yes & Yes & Yes & Yes & Yes & Yes & Yes & Yes & Yes & Yes & Yes & Yes & Yes & Yes & Yes & Yes & Yes \\
\hline After-Event Fixed Effects (389) & Yes & Yes & Yes & Yes & Yes & Yes & Yes & Yes & Yes & Yes & Yes & Yes & Yes & Yes & Yes & Yes & Yes & Yes & Yes & Yes & Yes & Yes & Yes & Yes & Yes \\
\hline Business-Year:Quarter Fixed Effects $(10,219)$ & Yes & Yes & Yes & Yes & Yes & Yes & Yes & Yes & Yes & y & Yes & Yes & Yes & Yes & Yes & Yes & Yes & Yes & Yes & Yes & Yes & Yes & Yes & Yes & Yes \\
\hline Industry Fixed Effects (17) & Yes & Yes & Yes & Yes & Yes & Yes & Yes & Yes & Yes & Yes & Yes & Yes & Yes & Yes & Yes & Yes & Yes & Yes & Yes & Yes & Yes & Yes & Yes & Yes & Yes \\
\hline Relationship and Firm Characteristics & Yes & Yes & Yes & Yes & Yes & Yes & Yes & Yes & Yes & Yes & Yes & Yes & Yes & Yes & Yes & Yes & Yes & Yes & Yes & Yes & Yes & Yes & Yes & Yes & Yes \\
\hline Adjusted R-squared & 0.12 & 0.12 & 0.12 & 0.12 & 0.12 & 0.13 & 0.13 & 0.13 & 0.13 & 0.13 & 0.09 & 0.09 & 0.09 & 0.09 & 0.09 & 0.34 & 0.34 & 0.34 & 0.34 & 0.34 & 0.14 & 0.14 & 0.14 & 0.14 & 0.14 \\
\hline
\end{tabular}

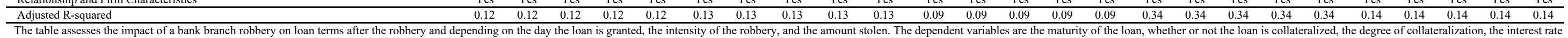

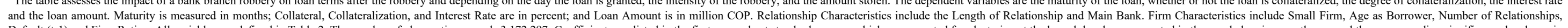

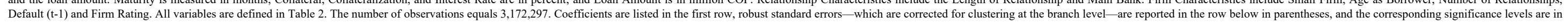
the adjacent column. ${ }^{* * *}$ significant at $1 \%,{ }^{* *}$ significant at $5 \%,{ }^{*}$ significant at $10 \%$. 
TABLE 5.-IMPACT ON LOAN PERFORMANCE AFTER BANK BRANCH ROBBERY

\begin{tabular}{|c|c|c|c|c|c|c|c|c|c|}
\hline \multirow[t]{2}{*}{ Models } & \multirow[b]{2}{*}{ Dependent Variables } & 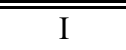 & 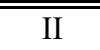 & III & IV & "I & "II & 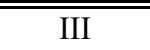 & IV \\
\hline & & \multicolumn{4}{|c|}{ Arrear } & \multicolumn{4}{|c|}{ Lenght of Arrear } \\
\hline Branch Robbed * After & & $\begin{array}{c}0.82 * * * \\
(0.18)\end{array}$ & $\begin{array}{c}0.97 \\
(0.68)\end{array}$ & $\begin{array}{c}0.71 * * * \\
(0.12)\end{array}$ & $\begin{array}{c}0.38 \\
(0.55)\end{array}$ & $\begin{array}{c}0.019 * * * \\
(0.005)\end{array}$ & $\begin{array}{c}0.026 \\
(0.019)\end{array}$ & $\begin{array}{c}0.016^{* * *} \\
(0.003)\end{array}$ & $\begin{array}{c}0.011 \\
(0.018)\end{array}$ \\
\hline Branch Robbed * After * $\ln$ (Days After the Robbery) & & & $\begin{array}{l}-0.04 \\
(0.18) \\
\end{array}$ & & $\begin{array}{c}0.09 \\
(0.14) \\
\end{array}$ & & $\begin{array}{l}-0.002 \\
(0.005) \\
\end{array}$ & & $\begin{array}{c}0.001 \\
(0.004) \\
\end{array}$ \\
\hline Branch-Event Fixed Effects $(150,699)$ & & Yes & Yes & Yes & Yes & Yes & Yes & Yes & Yes \\
\hline After-Event Fixed Effects (389) & & Yes & Yes & Yes & Yes & Yes & Yes & Yes & Yes \\
\hline Industry Fixed Effects (17) & & Yes & Yes & Yes & Yes & Yes & Yes & Yes & Yes \\
\hline Relationship and Firm Characteristics & & Yes & Yes & Yes & Yes & Yes & Yes & Yes & Yes \\
\hline Loan Characteristics & & No & No & Yes & Yes & No & No & Yes & Yes \\
\hline Adjusted R-squared & & 0.03 & 0.03 & 0.06 & 0.06 & 0.03 & 0.03 & 0.06 & 0.03 \\
\hline
\end{tabular}

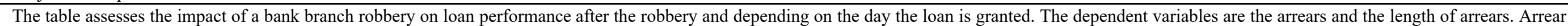

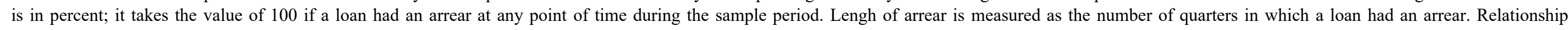

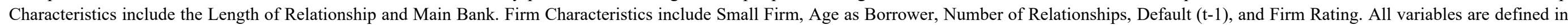

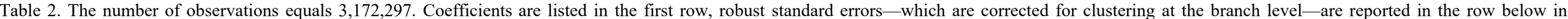
parentheses, and the corresponding significance levels are in the adjacent column. $* * *$ significant at $1 \%$, ** significant at $5 \%$, significant at $10 \%$. 
Panel A. PLACEBO: RANDOM ROBBERIES

\begin{tabular}{lcccc} 
Branch Robbed * After & 0.39 & $4.03^{*}$ & 0.14 & -2.07 \\
& $(0.24)$ & $(2.13)$ & $(0.60)$ & $(5.52)$ \\
Branch Robbed * After * In(Days After the Robbery) & & $-0.98^{*}$ & & 0.5 \\
& & $(0.55)$ & & $(1.52)$ \\
\hline Branch-Event Fixed Effects (140,504) & Yes & Yes & Yes & Y \\
After-Event Fixed Effects (333) & Yes & Yes & Yes & Y \\
Industry Fixed Effects (17) & Yes & Yes & Yes & Y \\
Relationship and Firm Characteristics & Yes & Yes & Yes & Y \\
\hline
\end{tabular}

\begin{tabular}{ccccccc}
-2.07 & -0.42 & -7.09 & 0.291 & -1.178 & 56.46 & 50.27 \\
$(5.52)$ & $(0.92)$ & $(5.11)$ & $(0.285)$ & $(1.694)$ & $(56.19)$ & $(350.07)$ \\
0.59 & & 1.80 & & 0.397 & & 1.67 \\
$(1.52)$ & & $(1.36)$ & & $(0.450)$ & & $(89.37)$ \\
\hline Yes & Yes & Yes & Yes & Yes & Yes & Yes \\
Yes & Yes & Yes & Yes & Yes & Yes & Yes \\
Yes & Yes & Yes & Yes & Yes & Yes & Yes \\
Yes & Yes & Yes & Yes & Yes & Yes & Yes \\
\hline 0.09 & 0.08 & 0.08 & 0.39 & 0.39 & 0.11 & 0.11
\end{tabular}

Adjusted R-squared

Panel B. PLACEBO: EXPECTED ROBBERIES

\begin{tabular}{|c|c|c|c|c|c|c|c|c|c|c|}
\hline Branch Robbed * After & $\begin{array}{c}0.51 \\
(0.361\end{array}$ & $\begin{array}{c}0.08 \\
(2.725\end{array}$ & $\begin{array}{l}1.28^{* *} \\
(0.65)\end{array}$ & $\begin{array}{l}-4.24 \\
(9.27)\end{array}$ & $\begin{array}{c}1.00 \\
(1.42)\end{array}$ & $\begin{array}{l}-6.00 \\
(8.22)\end{array}$ & $\begin{array}{c}0.087 \\
(0.199)\end{array}$ & $\begin{array}{c}0.500 \\
(1.751)\end{array}$ & $\begin{array}{c}46.44 \\
(51.60)\end{array}$ & $\begin{array}{c}21.04 \\
(296.34)\end{array}$ \\
\hline Branch Robbed * After * In(Days After the Robbery) & & $\begin{array}{c}0.12 \\
(0.80) \\
\end{array}$ & & $\begin{array}{c}1.56 \\
(2.56) \\
\end{array}$ & & $\begin{array}{r}1.98 \\
(2.32) \\
\end{array}$ & & $\begin{array}{l}-0.117 \\
(0.521) \\
\end{array}$ & & $\begin{array}{c}7.17 \\
(77.88) \\
\end{array}$ \\
\hline Branch-Event Fixed Effects $(6,675)$ & Yes & Yes & Yes & Yes & Yes & Yes & Yes & Yes & Yes & Yes \\
\hline Industry Fixed Effects (16) & Yes & Yes & Yes & Yes & Yes & Yes & Yes & Yes & Yes & Yes \\
\hline Relationship and Firm Characteristics & Yes & Yes & Yes & Yes & Yes & Yes & Yes & Yes & Yes & Yes \\
\hline Adjusted R-squared & 0.11 & 0.11 & 0.09 & 0.09 & 0.08 & 0.08 & 0.39 & 0.39 & 0.11 & 0.11 \\
\hline \multicolumn{11}{|l|}{ Panel C. REVISITATIONS } \\
\hline Branch Robbed * After & $\begin{array}{c}0.90^{* * *} \\
(0.33)\end{array}$ & $\begin{array}{l}6.60^{* *} \\
(3.05)\end{array}$ & $\begin{array}{l}-0.26 \\
(0.62)\end{array}$ & $\begin{array}{c}7.40 \\
(5.19)\end{array}$ & $\begin{array}{l}-1.42 \\
(1.33)\end{array}$ & $\begin{array}{c}7.62 * * * \\
(1.55)\end{array}$ & $\begin{array}{c}-0.584^{* * *} \\
(0.112)\end{array}$ & $\begin{array}{c}-1.478^{*} \\
(0.844)\end{array}$ & $\begin{array}{c}85.79^{* *} \\
(36.15)\end{array}$ & $\begin{array}{c}979.41^{* * *} \\
(369.16)\end{array}$ \\
\hline Branch Robbed * After * $\ln ($ Days After the Robbery) & & $\begin{array}{c}-1.55^{* *} \\
(0.73)\end{array}$ & & $\begin{array}{l}-2.08 \\
(1.41) \\
\end{array}$ & & $\begin{array}{c}-2.45^{* * * *} \\
(0.61) \\
\end{array}$ & & $\begin{array}{c}0.243 \\
(0.209) \\
\end{array}$ & & $\begin{array}{c}-242.47^{* *} \\
(95.12) \\
\end{array}$ \\
\hline Branch-Event Fixed Effects $(16,060)$ & Yes & Yes & Yes & Yes & Yes & Yes & Yes & Yes & Yes & Yes \\
\hline After-Event Fixed Effects (40) & Yes & Yes & Yes & Yes & Yes & Yes & Yes & Yes & Yes & Yes \\
\hline Industry Fixed Effects (16) & Yes & Yes & Yes & Yes & Yes & Yes & Yes & Yes & Yes & Yes \\
\hline Relationship and Firm Characteristics & Yes & Yes & Yes & Yes & Yes & Yes & Yes & Yes & Yes & Yes \\
\hline Adjusted R-squared & 0.09 & 0.09 & 0.10 & 0.10 & 0.08 . & -0.08 & 0.43 & 0.43 & 0.10 & 0.10 \\
\hline \multicolumn{11}{|l|}{ Panel D. MATCHED } \\
\hline Branch Robbed * After * $\ln ($ Days After the Robbery) & & $\begin{array}{c}-0.630 * * * \\
(0.161)\end{array}$ & & $\begin{array}{l}-0.25 \\
(0.46)\end{array}$ & & $\begin{array}{c}-0.66^{* *} \\
(0.33)\end{array}$ & & $\begin{array}{l}-0.088 \\
(0.200)\end{array}$ & & $\begin{array}{c}24.36 \\
(16.40)\end{array}$ \\
\hline Branch-Event Fixed Effects $(242,949)$ & Yes & Yes & Yes & Yes & Yes & Yes & Yes & Yes & Yes & Yes \\
\hline After-Event Fixed Effects (455) & Yes & Yes & Yes & Yes & Yes & Yes & Yes & Yes & Yes & Yes \\
\hline Industry Fixed Effects (17) & Yes & Yes & Yes & Yes & Yes & Yes & Yes & Yes & Yes & Yes \\
\hline Relationship and Firm Characteristics & Yes & Yes & Yes & Yes & Yes & Yes & Yes & Yes & Yes & Yes \\
\hline Adjusted R-squared & 0.14 & 0.14 & 0.10 & 0.10 & 0.11 & 0.11 & 0.39 & 0.39 & 0.10 & 0.10 \\
\hline
\end{tabular}


TABLE 7.-IMPACT ON LOAN TERMS AFTER BANK BRANCH ROBBERY ACCORDING TO THE NUMBER OF EMPLOYEES IN THE BRANCH AND LOAN AMOUNT

\begin{tabular}{|c|c|c|c|c|c|c|c|c|c|c|}
\hline Panel A. INTERACTIONS WITH NUMBER OF EMPLOYEES $\leq 8$ & \multicolumn{2}{|c|}{ Maturity } & \multicolumn{2}{|c|}{ Collateral } & \multicolumn{2}{|c|}{ Collateralization } & \multicolumn{2}{|c|}{ Interest Rate } & \multicolumn{2}{|c|}{ Loan Amount } \\
\hline Branch Robbed * After & $\begin{array}{c}0.688^{* * *} \\
(0.176)\end{array}$ & $\begin{array}{c}3.039^{* * *} \\
(0.830)\end{array}$ & $\begin{array}{c}0.36 \\
(0.29)\end{array}$ & $\begin{array}{l}2.98 \\
(2.83)\end{array}$ & $\begin{array}{l}-0.43 \\
(0.38)\end{array}$ & $\begin{array}{c}3.35^{* *} \\
(1.71)\end{array}$ & $\begin{array}{c}-0.371 * * * \\
(0.074)\end{array}$ & $\begin{array}{c}-0.260 \\
(0.839)\end{array}$ & $\begin{array}{l}35.78^{* *} \\
(14.40)\end{array}$ & $\begin{array}{c}49.97 \\
(67.17)\end{array}$ \\
\hline Branch Robbed * After * $\ln ($ Days After the Robbery $)$ & & $\begin{array}{c}(0.030) \\
-0.646^{* * * *} \\
(0.226)\end{array}$ & & $\begin{array}{l}-0.072 \\
-0.72 \\
(0.81)\end{array}$ & & $\begin{array}{c}-1.04 * * \\
(0.49)\end{array}$ & & $\begin{array}{l}-0.030) \\
-0.030 \\
(0.230)\end{array}$ & & $\begin{array}{l}-3.90 \\
(17.07)\end{array}$ \\
\hline Branch Robbed $*$ After $* \mathrm{~d}($ Number of Employees $\leq 8)$ & $1.249 *$ & $5.542^{*}$ & 1.44 & 9.33 & 2.37 & 13.53 & 0.582 & -0.210 & -16.00 & -408.17 \\
\hline & $(0.676)$ & (3.045) & (1.74) & $(7.88)$ & (1.51) & (12.49) & $(0.543)$ & (2.197) & (29.29) & (287.64) \\
\hline Branch Robbed $*$ After $* \ln ($ Days After the Robbery $) * d($ Number of Employees $\leq 8)$ & & $\begin{array}{l}-1.215^{*} \\
(0.690)\end{array}$ & & $\begin{array}{l}-2.23 \\
(1.75)\end{array}$ & & $\begin{array}{l}-3.15 \\
(3.11)\end{array}$ & & $\begin{array}{c}0.221 \\
(0.499)\end{array}$ & & $\begin{array}{l}109.81 \\
(87.34)\end{array}$ \\
\hline $\begin{array}{l}\text { Branch-Event Fixed Effects }(146,382) \\
\text { (n) }\end{array}$ & Yes & Yes & Yes & Yes & Yes & Yes & Yes & $\frac{\text { Yes }}{40 .+31)}$ & Yes & Yes \\
\hline After-Event Fixed Effects (378) & Yes & Yes & Yes & Yes & Yes & Yes & Yes & Yes & Yes & Yes \\
\hline Industry Fixed Effects (17) & Yes & Yes & Yes & Yes & Yes & Yes & Yes & Yes & Yes & Yes \\
\hline Relationship and Firm Characteristics & Yes & Yes & Yes & Yes & Yes & Yes & Yes & Yes & Yes & Yes \\
\hline Adjusted R-squared & 0.10 & 0.10 . & 0.10 & 0.10 & 0.08 . & 0.08 & 0.41 & 0.41 & 0.11 & 0.11 \\
\hline \multicolumn{11}{|l|}{ Panel B. INTERACTIONS WITH NUMBER OF EMPLOYEES } \\
\hline Branch Robbed * After & $2.285^{* * *}$ & $11.810^{* * *}$ & 2.71 & $22.89^{*}$ & 0.99 & $22.36^{*}$ & 0.372 & -0.517 & 53.91 & -552.29 \\
\hline & $(0.777)$ & $(4.359)$ & $(2.00)$ & (11.76) & (2.40) & (12.69) & $(0.722)$ & $(2.561)$ & (79.14) & (463.49) \\
\hline Branch Robbed * After $* \ln ($ Days After the Robbery $)$ & & $-2.603 * *$ & & $-5.52^{*}$ & & $-5.85^{*}$ & & 0.244 & & 166.32 \\
\hline & & $(1.159)$ & & $(3.00)$ & & $(3.32)$ & & $(0.580)$ & & $(135.22)$ \\
\hline Branch Robbed * After * In(Number of Employees) & $-0.561^{*}$ & $-3.121 *$ & -0.83 & -7.15 & -0.48 & -6.75 & -0.261 & 0.096 & -6.84 & 214.72 \\
\hline & $(0.295)$ & $(1.844)$ & $(0.73)$ & $(5.18)$ & $(0.93)$ & $(5.09)$ & $(0.280)$ & $(0.985)$ & (30.38) & $(169.48)$ \\
\hline Branch Robbed * After * $\ln ($ Days After the Robbery) * $\ln ($ Number of Employees) & & 0.698 & & 1.73 & & 1.71 & & -0.098 & & $\begin{array}{r}-60.82 \\
-(48.95\end{array}$ \\
\hline & & $(0.498)$ & Yes & $(1.36)$ & $\mathrm{Yes}$ & $\frac{(1.36)}{Y_{\text {es }}}$ & $Y{ }^{\prime}$ & $\frac{(0.242)}{\left.V_{s}\right)}$ & & $(48.95)$ \\
\hline $\begin{array}{l}\text { Branch-Event Fixed Effects (144,382) } \\
\text { After-Event Fixed Effects } 378)\end{array}$ & $\begin{array}{l}\text { Yes } \\
\text { Yes }\end{array}$ & Yes & Yes & Yes & Yes & Yes & Yes & Yes & Yes & Yes \\
\hline $\begin{array}{l}\text { Andustry Fixed Effects (17) } \\
\text { Intor }\end{array}$ & $\begin{array}{l}\text { Yes } \\
\text { Yes }\end{array}$ & $\begin{array}{l}\text { Yres } \\
\text { Yes }\end{array}$ & $\begin{array}{l}\text { Yes } \\
\text { Yes }\end{array}$ & $\begin{array}{l}\text { Yres } \\
\text { Yes }\end{array}$ & $\begin{array}{l}\text { Yes } \\
\text { Yes }\end{array}$ & $\begin{array}{l}\text { YYes } \\
\text { Yes }\end{array}$ & $\begin{array}{l}\text { Yes } \\
\text { Yes }\end{array}$ & $\begin{array}{l}\text { Yes } \\
\text { Yes }\end{array}$ & Yes & Yes \\
\hline Relationship and Firm Characteristics & Yes & Yes & Yes & Yes & Yes & Yes & Yes & $\begin{array}{l}\text { YYes } \\
\text { Yes }\end{array}$ & 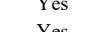 & Yes \\
\hline $\begin{array}{ll}\text { Adjusted R-squared } \\
\end{array}$ & 0.10 & 0.10 & 0.10 & 0.10 & 0.08 & 0.08 & 0.41 & 0.41 & 0.11 & 0.11 \\
\hline \multicolumn{11}{|l|}{ Panel C. INTERACTIONS WITH NUMBER OF EMPLOYEES $\leq 8$ FOR LOAN AMOUNT $\leq 25 \%$} \\
\hline Branch Robbed * After & 0.182 & $4.443 * * *$ & $1.88^{* * *}$ & $6.45 * * *$ & $1.02^{*}$ & $6.70^{* * *}$ & $-0.430 * *$ & 0.652 & $0.40^{* *}$ & 1.23 \\
\hline & $(0.139)$ & $(1.265)$ & $(0.81)$ & $(2.44)$ & $(0.58)$ & $(1.41)$ & $(0.176)$ & $(1.270)$ & $(0.20)$ & $(0.99)$ \\
\hline Branch Robbed * After * $\ln ($ Days After the Robbery $)$ & & $-1.160^{* * *}$ & & $-1.24^{*}$ & & $-1.55^{* * *}$ & & -0.295 & & -0.23 \\
\hline & & $(0.329)$ & & $(0.71)$ & & $(0.34)$ & & $(0.341)$ & & $(0.27)$ \\
\hline Branch Robbed * After * $\mathrm{d}($ Number of Employees $\leq 8)$ & $2.790^{* *}$ & $14.209 * * *$ & $9.32 * * *$ & $40.64 * * *$ & $10.48^{* * * *}$ & $43.23^{* * *}$ & -0.695 & $-7.405 * * *$ & $-1.73 * *$ & -2.52 \\
\hline & (1.327) & $(4.908)$ & (3.39) & $(10.65)$ & $(3.65)$ & $(10.95)$ & $(0.934)$ & $(1.952)$ & $(0.82)$ & $(4.53)$ \\
\hline Branch Robbed * After $* \ln ($ Days After the Robbery $) * d($ Number of Employees $\leq 8)$ & & $-3.183^{* * *}$ & & $-8.70^{* * *}$ & & $-9.10^{* * * *}$ & & $1.854^{* * *}$ & & 0.22 \\
\hline & & $(1.142)$ & & $(2.23)$ & & $(2.23)$ & & $(0.441)$ & & $(1.16)$ \\
\hline $\begin{array}{l}\text { Branch-Event Fixed Effects }(38,806) \\
\end{array}$ & Yes & Yes & Yes & Yes & Yes & Yes & Yes & Yes & Yes & Yes \\
\hline After-Event Fixed Effects (272) & Yes & Yes & Yes & Yes & Yes & Yes & Yes & Yes & Yes & Yes \\
\hline Industry Fixed Effects (17) & Yes & Yes & Yes & Yes & Yes & Yes & Yes & Yes & Yes & Yes \\
\hline Relationship and Firm Characteristics & Yes & Yes & Yes & Yes & Yes & Yes & Yes & Yes & Yes & Yes \\
\hline Adjusted R-squared & 0.17 & 0.17. & 0.10 & 0.10 & 0.11. & 0.11 & 0.77 & 0.77 & 0.22 & 0.22 \\
\hline \multicolumn{11}{|l|}{ Panel D. LOAN AMOUNT $\leq 25 \%$} \\
\hline Branch Robbed * After & $\begin{array}{c}0.385 * * \\
(0.164)\end{array}$ & $\begin{array}{c}2.351^{* * *} \\
(0.505)\end{array}$ & $\begin{array}{l}-0.55 \\
(0.46)\end{array}$ & $\begin{array}{c}2.75 \\
(1.70)\end{array}$ & $\begin{array}{c}-1.42 * * \\
(0.62)\end{array}$ & $\begin{array}{l}2.75 \\
(2.07)\end{array}$ & $\begin{array}{l}0.178^{* *} \\
(0.074)\end{array}$ & $\begin{array}{c}0.046 \\
(0.239)\end{array}$ & $\begin{array}{c}37.22 \\
(30.55)\end{array}$ & $\begin{array}{c}27.42 \\
(105.79)\end{array}$ \\
\hline Branch Robbed * After * $\ln ($ Days After the Robbery $)$ & & $-0.542 * * *$ & & $-0.91^{* *}$ & & $\begin{array}{l}-1.15 * * \\
-053\end{array}$ & & 0.036 & & 2.70 \\
\hline & & $(0.129)$ & & $(0.44)$ & & $(0.53)$ & & $(0.063)$ & & $(29.11)$ \\
\hline Branch Robbed * After * d(Loan Amount $\leq 25 \%)$ & $1.035^{* * *}$ & $2.731^{* *}$ & $2.78^{* * * *}$ & -0.17 & $3.22^{* * *}$ & 2.48 & $-1.582 * * *$ & -0.441 & -28.85 & -30.62 \\
\hline & $(0.298)$ & $(1.106)$ & $(0.88)$ & $(3.00)$ & $(1.02)$ & (3.54) & $(0.146)$ & $(0.469)$ & (59.97) & $(129.79)$ \\
\hline Branch Robbed * After * $\ln ($ Days After the Robbery) $* \mathrm{~d}($ Loan Amount $\leq 25 \%)$ & & -0.462 & & 0.81 & & 0.21 & & $-0.313 * *$ & & 0.47 \\
\hline & & $(0.282)$ & & $(0.77)$ & & $(0.89)$ & & $(0.122)$ & & $(33.54)$ \\
\hline $\begin{array}{l}\text { Branch-Event Fixed Effects }(150,699) \\
\text { (5) }\end{array}$ & Yes & Yes & Yes & Yes & Yes & Yes & Yes & Yes & Yes & Yes \\
\hline After-Event Fixed Effects (389) & Yes & Yes & Yes & Yes & Yes & Yes & Yes & Yes & Yes & Yes \\
\hline Industry Fixed Effects (17) & Yes & Yes & Yes & Yes & Yes & Yes & Yes & Yes & Yes & Yes \\
\hline Relationship and Firm Characteristics & Yes & Yes & Yes & Yes & Yes & Yes & Yes & Yes & Yes & Yes \\
\hline Adjusted R-squared & 0.10 & 0.10 & 0.10 & 0.10 & 0.09 & 0.09 & $\frac{\mathrm{res}}{042}$ & $\frac{1}{0.42}$ & 0.11 & 0.11 \\
\hline
\end{tabular}




\begin{tabular}{|c|c|c|c|c|}
\hline \multirow{2}{*}{ 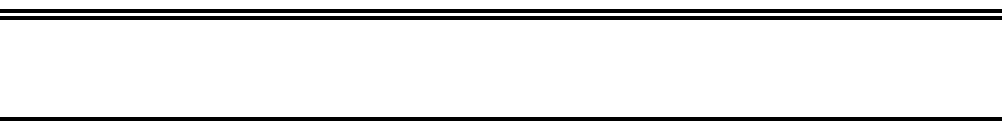 } & \multirow[b]{2}{*}{ Dependent Variable } & $\overline{\mathrm{I}}$ & II & \multirow[t]{2}{*}{ III } \\
\hline & & \multicolumn{2}{|c|}{ Number of Loans } & \\
\hline Branch Robbed * After & & $\begin{array}{c}-0.09 * * \\
(0.04)\end{array}$ & $\begin{array}{c}-1.55 * * * \\
(0.20)\end{array}$ & $\begin{array}{l}-0.29 \\
(0.41)\end{array}$ \\
\hline Branch Robbed $*$ After $* \ln ($ Days After the Robbery) & & & $\begin{array}{c}0.41 * * * \\
(0.05)\end{array}$ & $\begin{array}{c}0.04 \\
(0.11)\end{array}$ \\
\hline Branch Robbed $*$ After $*$ Firearm & & & & $\begin{array}{c}-1.29 * * * \\
(0.46)\end{array}$ \\
\hline Branch Robbed $*$ After $* \ln ($ Days After the Robbery) $*$ Firearm & & & & $\begin{array}{c}0.38 * * * \\
(0.12)\end{array}$ \\
\hline Branch-Event Fixed Effects $(150,699)$ & & Yes & Yes & Yes \\
\hline After-Event Fixed Effects (389) & & Yes & Yes & Yes \\
\hline Adjusted R-squared & & 0.24 & 0.24 & 0.24 \\
\hline
\end{tabular}

The table assesses the impact of a bank branch robbery on the number of loans originated after the robbery. The dependent variable is the number of loans granted per day. All other variables are defined in Table 2. The number of observations equals 1,570,038. Coefficients are listed in the first row, robust standard errors-which are corrected for clustering at the branch level-are reported in the row below in parentheses, and the corresponding significance levels are in the adjacent column. *** significant at $1 \%, * *$ significant at $5 \%, *$ significant at $10 \%$. 
TABLE 9.-IMPACT ON LENT AMOUNT AFTER BANK BRANCH ROBBERY

\begin{tabular}{|c|c|c|c|c|}
\hline Models & $\overline{\mathrm{I}}$ & $\overline{\mathrm{II}}$ & $\overline{\text { III }}$ & $\overline{\text { IV }}$ \\
\hline Dependent Variables & \multicolumn{4}{|c|}{ Lent Amount } \\
\hline \multirow[t]{2}{*}{ Branch Robbed * After } & $6,107 * *$ & $6,094 * *$ & $6,040 * *$ & $5,918^{*}$ \\
\hline & $(3,035)$ & $(3,036)$ & $(3,029)$ & $(3,0178)$ \\
\hline \multirow[t]{2}{*}{ Branch Robbed } & $105,534 * *$ & $105,799 * *$ & $-1,591$ & $-1,445$ \\
\hline & $(45,585)$ & $(45,784)$ & $(6,733)$ & $(6,578)$ \\
\hline \multirow[t]{2}{*}{ After } & $161 * * *$ & $174 * * *$ & $228 * * *$ & $351 * * *$ \\
\hline & $(53)$ & $(57)$ & $(57)$ & $(75)$ \\
\hline Event Fixed Effects (389) & no & yes & no & yes \\
\hline Branch Fixed Effects $(2,375)$ & no & no & yes & yes \\
\hline Adjusted R-squared & 0.01 & 0.01 & 0.76 & 0.77 \\
\hline
\end{tabular}

The table assesses the impact of a bank branch robbery on the lent amount after the robbery. The dependent variable is the total amount of credit granted in the branch. All other variables are defined in Table 2. The number of observations equals 513,050. Coefficients are listed in the first row, robust standard errors - which are corrected for clustering at the branch level - are reported in the row below in parentheses, and the corresponding significance levels are in the adjacent column. $* * *$ significant at $1 \%, * *$ significant at $5 \%, *$ significant at $10 \%$. 
Panel A. LOCAL TEAM WINS A GAME

Local Team Wins * After

Local Team Wins * After* $\ln ($ Days After the Game $)$

Municipality-Event Fixed Effects $(6,647)$

After-Event Fixed Effects (41)

Industry Fixed Effects (18)

Bank Fixed Effects (60)

Relationship and Firm Characteristics Adjusted R-squared Panel B. LOCAL TEAM PLAYS A GAME

\author{
Local Team Plays * After
}

Local Team Plays * After* $\ln ($ Days After the Game)

Municipality-Event Fixed Effects (26,674)

After-Event Fixed Effects (164)

Industry Fixed Effects (18)

Bank Fixed Effects (60)

Relationship and Firm Characteristics

Adjusted R-squared

$\begin{array}{ccc}-0.50^{* *} & -2.89^{* * *} & -1.3 \\ (0.24) & (0.66) & 0.41 \\ 0.39 * * * & 1.07 * * * & \\ (0.09) & (0.22) & \text { Yes } \\ \text { Yes } & \text { Yes } \\ \text { Yes } & \text { Yes } \\ \text { Yes } & \text { Yes } \\ \text { Yes } & \text { Yes } \\ \text { Yes } & 0.17-------1\end{array}$

\begin{tabular}{l}
$-1.30^{* * *}$ \\
$(0.37)$ \\
$0.41^{* * *}$ \\
$(0.08)$ \\
\hline Yes \\
Yes \\
Yes \\
Yes \\
Yes \\
\hline 0.22 \\
\hline
\end{tabular}

$0.38^{* * *}$

$(0.08)$

$-0.17 * * *$

(0.031)

Yes

Yes

Yes
Yes

Yes

Yes
Yes

0.26

\begin{tabular}{ccccc}
0.36 & $-2.33^{* * *}$ & $-0.86^{* *}$ & 0.10 & -92.12 \\
$(0.26)$ & $(0.44)$ & $(0.33)$ & $(0.08)$ & $(57.77)$ \\
0.10 & $0.95^{* * *}$ & $0.35^{* * *}$ & $-0.05^{*}$ & 0.17 \\
$(0.06)$ & $(0.06)$ & $(0.06)$ & $(0.03)$ & $(13.55)$ \\
\hline Yes & Yes & Yes & Yes & Yes \\
Yes & Yes & Yes & Yes & Yes \\
Yes & Yes & Yes & Yes & Yes \\
Yes & Yes & Yes & Yes & Yes \\
Yes & Yes & Yes & Yes & Yes \\
\hline 0.20 & 0.17 & 0.22 & 0.27 & 0.00 \\
\hline
\end{tabular}

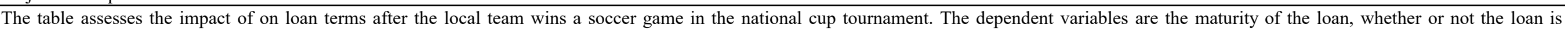

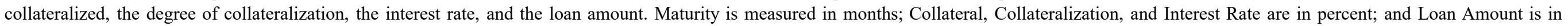

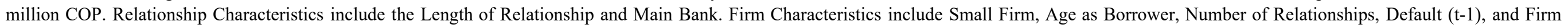

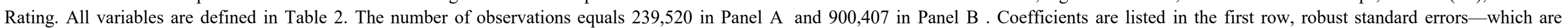

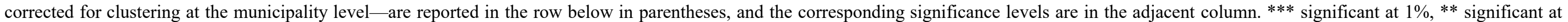
$5 \%$, * significant at $10 \%$. 
Appendix 
APPENDIX TABLE A.1.-PREDICTION OF ROBBERY TAKING PLACE IN A CERTAIN YEAR

\begin{tabular}{|c|c|c|c|c|c|c|c|c|c|c|c|c|c|c|c|c|c|c|c|c|}
\hline & \multirow{2}{*}{$\begin{array}{r}\text { Estimation } \\
\text { Year }\end{array}$} & \multicolumn{10}{|c|}{ Ordinary Least Squares } & \multicolumn{9}{|c|}{ Logit } \\
\hline & & 2002 & 2003 & 2004 & 2005 & 2006 & 2007 & 2008 & 2009 & 2010 & $2002-2010$ & 2002 & 2003 & 2004 & 2005 & 2006 & 2007 & 2008 & 2009 & 2010 \\
\hline Mean of Loan Amount $t_{\text {bmt-1 }}$ & & $\begin{array}{l}-0.004 \\
(0.002)\end{array}$ & $\begin{array}{l}-0.002 \\
(0.001)\end{array}$ & $\begin{array}{l}-0.001 \\
(0.001)\end{array}$ & $\begin{array}{l}-0.000 \\
(0.000)\end{array}$ & $\begin{array}{l}-0.001 \\
(0.001)\end{array}$ & $\begin{array}{c}-0.002 * * \\
(0.001)\end{array}$ & $\begin{array}{c}0.000 \\
(0.000)\end{array}$ & $\begin{array}{l}-0.001 \\
(0.001)\end{array}$ & $\begin{array}{l}-0.001 \\
(0.000)\end{array}$ & $\begin{array}{l}-0.001 \\
(0.000)\end{array}$ & $\begin{array}{l}-0.000^{*} \\
(0.000)\end{array}$ & $\begin{array}{l}-0.000 \\
(0.000)\end{array}$ & $\begin{array}{l}-0.001^{* *} \\
(0.000)\end{array}$ & $\begin{array}{c}-0.001 * * \\
(0.000)\end{array}$ & $\begin{array}{l}-0.000 \\
(0.000)\end{array}$ & $\begin{array}{c}-0.001 * * * \\
(0.000)\end{array}$ & $\begin{array}{l}-0.000 \\
(0.000)\end{array}$ & $\begin{array}{c}-0.001 * * * \\
(0.000)\end{array}$ & $\begin{array}{l}-0.001^{*} \\
(0.000)\end{array}$ \\
\hline Variance of Loan Amount $t_{b m t-1}$ & & $\begin{array}{l}0.000^{*} \\
(0.000)\end{array}$ & $\begin{array}{c}0.000 \\
(0.000)\end{array}$ & $\begin{array}{c}0.000 \\
(0.000)\end{array}$ & $\begin{array}{c}-0.000^{* * *} \\
(0.000)\end{array}$ & $\begin{array}{l}-0.000 \\
(0.000)\end{array}$ & $\begin{array}{c}0.000 \\
(0.000)\end{array}$ & $\begin{array}{l}-0.000 \\
(0.000)\end{array}$ & $\begin{array}{c}0.000 \\
(0.000)\end{array}$ & $\begin{array}{l}-0.000 \\
(0.000)\end{array}$ & $\begin{array}{c}0.000 \\
(0.000)\end{array}$ & $\begin{array}{l}-0.000 \\
(0.000)\end{array}$ & $\begin{array}{c}0.000 \\
(0.000)\end{array}$ & $\begin{array}{c}0.000 \\
(0.000)\end{array}$ & $\begin{array}{l}0.000^{* *} \\
(0.000)\end{array}$ & $\begin{array}{c}0.000 \\
(0.000)\end{array}$ & $\begin{array}{c}0.000 \\
(0.000)\end{array}$ & $\begin{array}{l}-0.000 \\
(0.000)\end{array}$ & $\begin{array}{c}0.000 * * * \\
(0.000)\end{array}$ & $\begin{array}{l}0.000^{* *} \\
(0.000)\end{array}$ \\
\hline Mean of Loan Maturity $y_{b m t-1}$ & & $\begin{array}{c}0.188 \\
(0.253)\end{array}$ & $\begin{array}{l}-0.054 \\
(0.143)\end{array}$ & $\begin{array}{c}0.137 \\
(0.123)\end{array}$ & $\begin{array}{c}0.211 \\
(0.144)\end{array}$ & $\begin{array}{l}-0.017 \\
(0.067)\end{array}$ & $\begin{array}{c}0.201 \\
(0.125)\end{array}$ & $\begin{array}{c}0.001 \\
(0.108)\end{array}$ & $\begin{array}{c}0.076 \\
(0.081)\end{array}$ & $\begin{array}{l}-0.024 \\
(0.042)\end{array}$ & $\begin{array}{l}0.057^{*} \\
(0.031)\end{array}$ & $\begin{array}{l}0.056^{* *} \\
(0.023)\end{array}$ & $\begin{array}{c}0.033^{* * * *} \\
(0.008)\end{array}$ & $\begin{array}{c}0.056^{* * *} \\
(0.012)\end{array}$ & $\begin{array}{c}0.055^{* * *} \\
(0.014)\end{array}$ & $\begin{array}{c}0.047 * * * \\
(0.011)\end{array}$ & $\begin{array}{c}0.014 \\
(0.010)\end{array}$ & $\begin{array}{l}-0.007 \\
(0.016)\end{array}$ & $\begin{array}{l}0.040^{* *} \\
(0.019)\end{array}$ & $\begin{array}{l}-0.002 \\
(0.010)\end{array}$ \\
\hline Variance of Loan Maturity $\mathrm{bmt}_{\mathrm{bm}-1}$ & & $\begin{array}{l}-0.000 \\
(0.001)\end{array}$ & $\begin{array}{l}-0.002 \\
(0.002)\end{array}$ & $\begin{array}{l}-0.000 \\
(0.000)\end{array}$ & $\begin{array}{l}-0.001 \\
(0.001)\end{array}$ & $\begin{array}{l}-0.000 \\
(0.000)\end{array}$ & $\begin{array}{l}-0.002 \\
(0.001)\end{array}$ & $\begin{array}{l}-0.001 \\
(0.001)\end{array}$ & $\begin{array}{l}-0.000 \\
(0.000)\end{array}$ & $\begin{array}{l}-0.000 \\
(0.000)\end{array}$ & $\begin{array}{l}-0.000^{*} \\
(0.000)\end{array}$ & $\begin{array}{c}-0.000 * * * \\
(0.000)\end{array}$ & $\begin{array}{l}-0.000^{*} \\
(0.000)\end{array}$ & $\begin{array}{c}-0.000 * * * \\
(0.000)\end{array}$ & $\begin{array}{l}-0.000^{*} \\
(0.000)\end{array}$ & $\begin{array}{c}-0.001^{* *} \\
(0.000)\end{array}$ & $\begin{array}{l}-0.000 \\
(0.000)\end{array}$ & $\begin{array}{l}-0.000 \\
(0.000)\end{array}$ & $\begin{array}{l}-0.000^{* * *} \\
(0.000)\end{array}$ & $\begin{array}{l}-0.000 \\
(0.000)\end{array}$ \\
\hline Mean of Loan Interest Rate ${ }_{b m t-1}$ & & $\begin{array}{l}-0.343 \\
(0.422)\end{array}$ & $\begin{array}{c}-0.332^{* * *} \\
(0.163)\end{array}$ & $\begin{array}{c}0.068 \\
(0.108)\end{array}$ & $\begin{array}{l}0.235^{* *} \\
(0.116)\end{array}$ & $\begin{array}{l}-0.054 \\
(0.099)\end{array}$ & $\begin{array}{l}-0.258 \\
(0.184)\end{array}$ & $\begin{array}{l}-0.129 \\
(0.248)\end{array}$ & $\begin{array}{l}-0.086 \\
(0.160)\end{array}$ & $\begin{array}{l}-0.095 \\
(0.183)\end{array}$ & $\begin{array}{l}-0.030 \\
(0.065)\end{array}$ & $\begin{array}{l}-0.045 \\
(0.034)\end{array}$ & $\begin{array}{c}-0.066^{* * *} \\
(0.024)\end{array}$ & $\begin{array}{l}-0.013 \\
(0.019)\end{array}$ & $\begin{array}{l}-0.006 \\
(0.032)\end{array}$ & $\begin{array}{l}-0.017 \\
(0.022)\end{array}$ & $\begin{array}{l}-0.051^{*} \\
(0.029)\end{array}$ & $\begin{array}{l}-0.013 \\
(0.034)\end{array}$ & $\begin{array}{l}-0.047 \\
(0.057)\end{array}$ & $\begin{array}{l}-0.076 \\
(0.059)\end{array}$ \\
\hline Variance of Loan Interest Rate bmt-1 $_{1}$ & & $\begin{array}{l}-0.032 \\
(0.045)\end{array}$ & $\begin{array}{l}-0.008 \\
(0.029)\end{array}$ & $\begin{array}{l}-0.000 \\
(0.019)\end{array}$ & $\begin{array}{c}0.027 \\
(0.021)\end{array}$ & $\begin{array}{l}0.057^{*} \\
(0.033)\end{array}$ & $\begin{array}{c}0.046 \\
(0.030)\end{array}$ & $\begin{array}{l}0.047^{*} \\
(0.027)\end{array}$ & $\begin{array}{l}0.048^{* *} \\
(0.022)\end{array}$ & $\begin{array}{l}0.038^{* *} \\
(0.019)\end{array}$ & $\begin{array}{c}0.006 \\
(0.007)\end{array}$ & $\begin{array}{l}-0.001 \\
(0.004)\end{array}$ & $\begin{array}{c}0.003 \\
(0.003)\end{array}$ & $\begin{array}{c}0.003 \\
(0.002)\end{array}$ & $\begin{array}{c}0.009^{* * *} \\
(0.003)\end{array}$ & $\begin{array}{c}0.016^{* * *} \\
(0.003)\end{array}$ & $\begin{array}{c}0.013 * * * \\
(0.004)\end{array}$ & $\begin{array}{c}0.005^{* * *} \\
(0.002)\end{array}$ & $\begin{array}{c}0.013 * * * \\
(0.003)\end{array}$ & $\begin{array}{c}0.009^{* * * *} \\
(0.003)\end{array}$ \\
\hline Mean of Loan Percentage Collateral $b_{b m t-1}$ & & $\begin{array}{l}-0.091 \\
(0.057)\end{array}$ & $\begin{array}{l}-0.029^{*} \\
(0.017)\end{array}$ & $\begin{array}{l}-0.061 \\
(0.054)\end{array}$ & $\begin{array}{l}-0.020 \\
(0.058)\end{array}$ & $\begin{array}{l}-0.067^{* * *} \\
(0.034)\end{array}$ & $\begin{array}{l}-0.015 \\
(0.038)\end{array}$ & $\begin{array}{l}-0.059 \\
(0.064)\end{array}$ & $\begin{array}{l}-0.051 \\
(0.033)\end{array}$ & $\begin{array}{l}-0.040 \\
(0.033)\end{array}$ & $\begin{array}{c}-0.037 * * * \\
(0.012)\end{array}$ & $\begin{array}{c}-0.009 * * * \\
(0.002)\end{array}$ & $\begin{array}{l}-0.002 \\
(0.002)\end{array}$ & $\begin{array}{l}-0.004 \\
(0.006)\end{array}$ & $\begin{array}{l}-0.003 \\
(0.006)\end{array}$ & $\begin{array}{c}-0.010^{* *} \\
(0.004)\end{array}$ & $\begin{array}{c}0.003 \\
(0.004)\end{array}$ & $\begin{array}{l}-0.008 \\
(0.009)\end{array}$ & $\begin{array}{l}-0.014 \\
(0.009)\end{array}$ & $\begin{array}{c}-0.018 * * * \\
(0.007)\end{array}$ \\
\hline Variance of Loan Percentage Collateral ${ }_{b m t-1}$ & & $\begin{array}{c}0.011 \\
(0.016)\end{array}$ & $\begin{array}{c}-0.015^{* *} \\
(0.006)\end{array}$ & $\begin{array}{c}0.011 \\
(0.008)\end{array}$ & $\begin{array}{c}0.001 \\
(0.008)\end{array}$ & $\begin{array}{c}0.011 \\
(0.008)\end{array}$ & $\begin{array}{l}0.000 \\
(0.007)\end{array}$ & $\begin{array}{c}0.011 \\
(0.017)\end{array}$ & $\begin{array}{c}0.007 \\
(0.005)\end{array}$ & $\begin{array}{c}0.008 \\
(0.006)\end{array}$ & $\begin{array}{l}0.004^{*} \\
(0.002)\end{array}$ & $\begin{array}{l}0.002^{*} \\
(0.001)\end{array}$ & $\begin{array}{c}0.000 \\
(0.001)\end{array}$ & $\begin{array}{c}0.001 \\
(0.001)\end{array}$ & $\begin{array}{c}0.001 \\
(0.001)\end{array}$ & $\begin{array}{c}0.002 \\
(0.001)\end{array}$ & $\begin{array}{l}-0.001 \\
(0.001)\end{array}$ & $\begin{array}{c}0.002 \\
(0.002)\end{array}$ & $\begin{array}{c}0.001 \\
(0.001)\end{array}$ & $\begin{array}{c}0.003 * * * \\
(0.001)\end{array}$ \\
\hline Mean of Loan Rating $g_{b m t-1}$ & & $\begin{array}{c}0.297 \\
(5.164)\end{array}$ & $\begin{array}{c}2.222 \\
(4.389)\end{array}$ & $\begin{array}{c}5.939 \\
(3.922)\end{array}$ & $\begin{array}{c}2.402 \\
(3.766)\end{array}$ & $\begin{array}{c}0.104 \\
(2.473)\end{array}$ & $\begin{array}{c}2.261 \\
(2.211)\end{array}$ & $\begin{array}{l}-23.106 \\
(20.789)\end{array}$ & $\begin{array}{c}1.402 \\
(1.787)\end{array}$ & $\begin{array}{l}-0.314 \\
(1.066)\end{array}$ & $\begin{array}{l}2.384 * \\
(1.293)\end{array}$ & $\begin{array}{l}2.039 * * \\
(0.960)\end{array}$ & $\begin{array}{c}1.104 \\
(0.749)\end{array}$ & $\begin{array}{c}1.705^{* * *} \\
(0.643)\end{array}$ & $\begin{array}{l}2.257^{* *} \\
(0.954)\end{array}$ & $\begin{array}{c}1.503 \\
(1.046)\end{array}$ & $\begin{array}{l}3.982^{*} \\
(2.205)\end{array}$ & $\begin{array}{l}-2.791^{*} \\
(1.677)\end{array}$ & $\begin{array}{l}1.375^{*} \\
(0.804)\end{array}$ & $\begin{array}{c}0.651 \\
(0.544)\end{array}$ \\
\hline Variance of Loan Rating $\mathrm{bmtt}_{\mathrm{b}}$ & & $\begin{array}{c}-0.973 \\
(1.701)\end{array}$ & $\begin{array}{c}3.719 \\
(2.965)\end{array}$ & $\begin{array}{c}1.726 \\
(1.066)\end{array}$ & $\begin{array}{c}1.097 \\
(1.343)\end{array}$ & $\begin{array}{c}-0.172 \\
(0.913)\end{array}$ & $\begin{array}{c}0.868 \\
(1.747)\end{array}$ & $\begin{array}{c}-7.697 \\
(7.208)\end{array}$ & $\begin{array}{c}1.335 \\
(1.295)\end{array}$ & $\begin{array}{l}-0.074 \\
(0.355)\end{array}$ & $\begin{array}{l}-0.798 \\
(0.574)\end{array}$ & $\begin{array}{c}0.120 \\
(0.220)\end{array}$ & $\begin{array}{c}0.336 \\
(0.343)\end{array}$ & $\begin{array}{c}0.215 \\
(0.280)\end{array}$ & $\begin{array}{c}0.160 \\
(0.277)\end{array}$ & $\begin{array}{c}0.408 \\
(0.425)\end{array}$ & $\begin{array}{c}0.926 \\
(0.671)\end{array}$ & $\begin{array}{l}-1.155 \\
(1.221)\end{array}$ & $\begin{array}{c}0.540^{* *} \\
(0.265)\end{array}$ & $\begin{array}{c}0.178 \\
(0.178)\end{array}$ \\
\hline Total Loan Amount ${ }_{\text {bmt-1 }}$ & & $\begin{array}{c}0.000^{* * * *} \\
(0.000)\end{array}$ & $\begin{array}{c}0.000^{* * * *} \\
(0.000)\end{array}$ & $\begin{array}{c}0.000^{* * *} \\
(0.000)\end{array}$ & $\begin{array}{c}0.000^{* * *} \\
(0.000)\end{array}$ & $\begin{array}{l}-0.000 \\
(0.000)\end{array}$ & $\begin{array}{c}0.000^{* * *} \\
(0.000)\end{array}$ & $\begin{array}{c}0.000^{* * *} \\
(0.000)\end{array}$ & $\begin{array}{c}0.000^{* * *} \\
(0.000)\end{array}$ & $\begin{array}{c}0.000^{* * *} \\
(0.000)\end{array}$ & $\begin{array}{c}0.000 * * * \\
(0.000)\end{array}$ & $\begin{array}{c}0.000^{* * *} * \\
(0.000)\end{array}$ & $\begin{array}{c}0.000 \\
(0.000)\end{array}$ & $\begin{array}{c}0.000^{* * *} \\
(0.000)\end{array}$ & $\begin{array}{c}0.000 * * * \\
(0.000)\end{array}$ & $\begin{array}{c}0.000 \\
(0.000)\end{array}$ & $\begin{array}{c}0.000 \\
(0.000)\end{array}$ & $\begin{array}{c}0.000 \\
(0.000)\end{array}$ & $\begin{array}{l}0.000^{* * *} \\
(0.000)\end{array}$ & $\begin{array}{c}0.000^{* * * *} \\
(0.000)\end{array}$ \\
\hline Constant & & $\begin{array}{c}27.473 \\
(23.931)\end{array}$ & $\begin{array}{c}9.194 \\
(20.380)\end{array}$ & $\begin{array}{l}-23.849 \\
(21.327)\end{array}$ & $\begin{array}{l}-12.078 \\
(20.437)\end{array}$ & $\begin{array}{c}5.875 \\
(12.979)\end{array}$ & $\begin{array}{c}-0.393 \\
(11.971)\end{array}$ & $\begin{array}{c}123.145 \\
(103.503)\end{array}$ & $\begin{array}{l}-1.944 \\
(8.034)\end{array}$ & $\begin{array}{c}9.013 \\
(5.564)\end{array}$ & $\begin{array}{l}-4.419 \\
(6.045)\end{array}$ & $\begin{array}{c}-11.099^{* *} \\
(4.673)\end{array}$ & $\begin{array}{l}-6.585^{*} \\
(3.822)\end{array}$ & $\begin{array}{c}-11.517^{* * *}- \\
(3.395)\end{array}$ & $\begin{array}{c}-14.481 * * * \\
(4.886)\end{array}$ & $\begin{array}{c}-10.886^{* *} \\
(5.194)\end{array}$ & $\begin{array}{c}-21.934 * * \\
(11.166)\end{array}$ & $\begin{array}{l}11.333 \\
(8.413)\end{array}$ & $\begin{array}{c}-9.785^{* *} \\
(3.979)\end{array}$ & $\begin{array}{l}-5.433 * \\
(2.855)\end{array}$ \\
\hline ed Effects & & Yes & Yes & Yes & Yes & Yes & Yes & Yes & Yes & Yes & Yes & No & No & No & No & No & No & No & No & No \\
\hline Number of Observations & & 502 & 548 & 798 & 925 & 826 & 946 & 833 & 909 & 1,030 & 8,208 & 502 & 548 & 798 & 925 & 826 & 946 & 833 & 909 & 1,030 \\
\hline Adjusted R-squared & & 0.378 & 0.289 & 0.363 & 0.288 & 0.265 & 0.449 & 0.154 & 0.356 & 0.447 & 0.313 & - & & 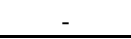 & 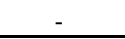 & - & 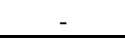 & - & - & - \\
\hline
\end{tabular}

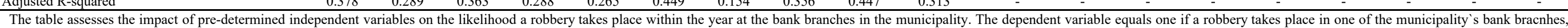

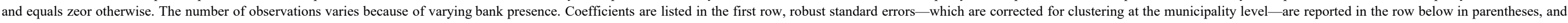
the corresponding significance levels are in the adjacent column. *** significant at $1 \%, * *$ significant at $5 \%, *$ significant at $10 \%$. 
APPENDIX TABLE A.2.-PREDICTION OF ROBBERY TAKING PLACE IN A CERTAIN QUARTER - ORDINARY LEAST SQUARES

$\begin{array}{llllllllllllllll}2008 & 2008 & 2008 & 2009 & 2009 & 2009 & 2009 & 2010 & 2010 & 2010 & 2010 & 2002 \cdot \mathrm{V}-2010 \cdot \mathrm{IV}\end{array}$

\begin{tabular}{|c|c|c|c|c|c|c|c|c|c|c|c|c|c|c|c|c|c|c|c|c|c|c|c|c|c|c|c|c|c|c|c|c|c|c|}
\hline Quarter & IV & 1 & II & III & IV & I & II & III & IV & $\mathrm{I}$ & II & III & IV & I & II & III & IV & I & II & III & IV & I & II & III & IV & I & II & III & IV & I & II & III & IV & \\
\hline$\overline{\text { Mean of Loan Amount } \text { tont-1 }^{-1}}$ & -0.004 & $0.007^{* * * *}$ & -0.003 & -0.001 & -0.001 & -0.001 & -0.004 & -0.001 & -0.002 & -0.001 & -0.004 & -0.003 & -0.003 & $\begin{array}{c}-0.002 \\
\end{array}$ & $-0.003^{* * *}$ & -0.001 & -0.001 & 0.001 & 0.000 & -0.001 & 0.001 & -0.001 & -0.001 & $-0.004 * *$ & 0.000 & -0.001 & 0.000 & -0.001 & $-0.002^{*}$ & -0.002 & -0.002 & -0.002 & 0.001 & $-0.001 * * *$ \\
\hline & $(0.005)$ & & $(0.003)$ & $(0.001)$ & $(0.003)$ & (0.001) & & $(0.003)$ & $(0.002)$ & & & (0.002) & & 2) & $(0.001)$ & & & & & & $(0.001)$ & & & & & & & & & & & & & \\
\hline ance of Loan Amou & & & & & & & & & & & & & & & & & & & & & & & & & & & & & & & & & & \\
\hline & & $(0.000)$ & $(0.000)$ & $(0.000)$ & $(0.000)$ & $(0.000)$ & $(0.000)$ & $(0.000)$ & $(0.000)$ & $(0.000)$ & $(0.000)$ & $(0.000)$ & $(0.000)$ & & $(0.000)$ & $(0.000)$ & $(0.000)$ & $(0.000)$ & & & $(0.000)$ & $(0.000)$ & $(0.000)$ & $(0.000)$ & $(0.00 \mathrm{C}$ & & & $(0.0-0)>0$ & $(0.00$ & $(0.000)$ & (0.0000) & 600) & & \\
\hline Mean of Loan Maturityom-1 & 0.054 & 0.375 & -0.079 & 0.004 & -0.207 & 0.009 & 0.096 & -0.260 & 0.018 & 0.250 & 0.149 & 0.002 & 0.052 & -0.041 & 0.299 & 0.058 & 0.205 & -0.027 & -0.029 & 0.175 & 0.079 & 0.429 & 0.170 & 0.078 & -0.006 & -0.067 & 0.020 & -0.054 & $-0.080^{*}$ & 0.002 & -0.108 & 0.104 & 0.015 & $0.027 * *$ \\
\hline & $(0.570)$ & $(0.471)$ & $(0.432)$ & $(0.129)$ & $(0.150)$ & $(0.150)$ & $(0.126)$ & $(0.159)$ & $(0.037)$ & $(0.278)$ & $(0.126)$ & $(0.146)$ & $(0.103)$ & $(0.108)$ & $(0.223)$ & $(0.133)$ & $(0.162)$ & $(0.110)$ & $(0.076)$ & $(0.129)$ & $(0.101)$ & $(0.338)$ & $(0.153)$ & $(0.151)$ & $(0.117)$ & $(0.098)$ & $(0.108)$ & $(0.046)$ & $(0.044)$ & $(0.067)$ & $(0.104)$ & $(0.081)$ & 45) & \\
\hline ance of Loan Maturityom-1 & & & & & & & & & & & & & & & & & & & & & & & & & & & & & & & & & & \\
\hline & & $(0.002)$ & $(0.002)$ & & & $(0.001)$ & & 01) & $(0.000)$ & .001) & (0.001) & $(0.001)$ & $(0.001)$ & $(0.000)$ & $(0.001)$ & $(0.000)$ & $(0.001)$ & $(0.0$ & $(0.0$ & $(0.003)$ & $(0.001)$ & $(0.002)$ & $(0.001)$ & $(0.001)$ & $(0.001)$ & $(0.001)$ & $(0.001)$ & $(0.000)$ & 10) & .000) & & & & \\
\hline cean of Loan Interess Rat Ratm: & 0. & -0.591 & $-0.594^{*}$ & & & 0.125 & & & -0.070 & 0.234 & & -0.040 & & -0.013 & 0.140 & & & & & & & & & & & & & & & & & & & \\
\hline & & $(0.402)$ & $(0.325)$ & $(0.284)$ & $(0.071)$ & $(0.111)$ & $(0.234)$ & $(0.193)$ & $(0.155)$ & $(0.156)$ & $(0.176)$ & $(0.217)$ & $(0.176)$ & $(0.212)$ & $(0.217)$ & & $(0.229)$ & & & $(0.210)$ & $(0.469)$ & $(0.274)$ & & $(0.333)$ & & $(0.414)$ & $(0.231)$ & & 52) & & $(0.107)$ & 146) & & \\
\hline Variance of Loan Interest Rat, & -0.082 & -0.037 & -0.026 & -0.018 & -0.021 & & & & 0.021 & -0.015 & & 0.002 & & & 0.003 & -0.006 & & -0.026 & 0013 & & 0.002 & & 0.016 & 0.025 & 0015 & 0.036 & 0013 & (1) & 0013 & $0010^{*}$ & $0000^{-}$ & .004 & & \\
\hline & & $(0.054)$ & $(0.019)$ & $(0.073)$ & $(0.019)$ & $(0.027)$ & $(0.048)$ & $(0.061)$ & $(0.015)$ & $(0.014)$ & $(0.019)$ & $(0.031)$ & $(0.020)$ & $(0.011)$ & $(0.018)$ & $(0.017)$ & $(0.071)$ & $(0.021)$ & $(0.016)$ & $(0.025)$ & $(0.014)$ & $(0.019)$ & $(0.017)$ & $(0.018)$ & $(0.019)$ & .025) & $(0.022)$ & $(0.012)$ & $(0.018)$ & $(0.011)$ & $(0.013)$ & .013) & 37) & 103) \\
\hline in of Loan Percentage Collater. & & & & -0.026 & & & & & & & & & & & & & & & & & & & & & & & & & & & & & & \\
\hline & & $(0.094)$ & $(0.057)$ & $(0.133)$ & (0. & $(0.028)$ & (0.07) & $(0.041)$ & $(0.046)$ & $(0.055)$ & $(0.023)$ & 70) & $(0$. & $(0.038)$ & $(0.055)$ & $(0.014)$ & $(0.033)$ & $(0.051)$ & $(0.034)$ & $(0.053)$ & $(0.0$ & $(0$ & (0.0034) & (0.0888) & $(0.056)$ & $(0.035)$ & $(0.039)$ & $(0.036)$ & (0.035) & (0.023) & (0.021) & (5) & & \\
\hline Variance of Loon Percentage Collaterablm, & & & 0.0 & & & & & & & & & & & & & & & & & & & & & & & & & & & & & & & \\
\hline & & & & & & $(0.013)$ & $(0.0$ & $(0.012)$ & $(0.006)$ & $(0.009)$ & $(0.012)$ & $(0.013)$ & $(0.031)$ & $(0.008)$ & $(0.013)$ & $(0.009)$ & $(0.004)$ & $(0.004)$ & $(0.007)$ & (0.011) & $(0.004)$ & $(0.100)$ & $(0.014)$ & $(0.012)$ & $(0.008)$ & $(0.008)$ & $(0.005)$ & $(0.008)$ & (0.005) & $(0.005)$ & (0.004) & 009) & 11) & \\
\hline Mean of Loan Rating gaturt 1 & & 9.894 & $-36.264^{*}$ & 0.046 & -7.256 & & & & & 9.103 & & & & & & & & & & & & & & & & & & & & & & & & \\
\hline & & $(19.562)$ & $(21.068)$ & $(6.050)$ & $(13.243)$ & & & $(19.492)$ & $(4.717)$ & & & $(18.677)$ & & & $(10.533)$ & $(8.985)$ & & & & $(10.250)$ & $(8.421)$ & $(15.980)$ & & $(7.424)$ & $(21.993)$ & & $(5.208)$ & $(6.326)$ & & 01) & 94) & 78) & 47) & \\
\hline Lo: & & -26.798 & $-6.44>2>3$ & & & 95 & & & 1.312 & 3. & & & & & 2.979 & & & & & & & & & & & & & & & & & & & \\
\hline & & 48) & $(11.4$ & & 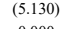 & 296) & (3.) & ( & $(1.287)$ & (3.841) & (90.0003) & $(5.188)$ & (3.258) & $(2.300)$ & $(2.431)$ & (8.9031) & $(2.000)$ & (1.180) & & & $(2.7$ & (4.917) & (1.215) & (2.80) & (8.8803) & $(1,000)$ & (2.310) & .000 & & & & 200 & & \\
\hline ountment & & & & & & & & & & & & & & & & & & & & & & & & & & & & & & & & & & \\
\hline & & $(0.0$ & $(0.000)$ & & & (5.0 & (0.) & $(0.000)$ & $(0.000)$ & $(0.000)$ & $(0.000)$ & $(0.000)$ & $(0.000)$ & $(0.000)$ & $(0.000)$ & $(0.000)$ & $(0.000)$ & $(0.000)$ & $(0.000)$ & $(0.000)$ & $(0.000)$ & $(0.000)$ & $(0.000)$ & $(0.000)$ & $(0.000)$ & $(0.000)$ & $(0.000)$ & $(0.000)$ & 000) & $(0.000)$ & $(0.000)$ & $(0.000)$ & $(0.000)$ & 00) \\
\hline stant & $\left.\begin{array}{l}1717.799 \\
(149.343)\end{array}\right)$ & $\begin{array}{c}-24 . \\
(100 . \\
c\end{array}$ & & $\begin{array}{l}10.201 \\
(30.241)\end{array}$ & 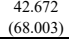 & $\begin{array}{l}-25.7 .57 \\
3.526)\end{array}$ & $\begin{array}{l}599755 \\
(84.301)\end{array}$ & $\begin{array}{l}34.58 \\
(93.458)\end{array}$ & $\begin{array}{l}-24.722 \\
(22.418)\end{array}$ & $\begin{array}{r}-48.113 \\
(39.525)\end{array}$ & $\begin{array}{l}-1122.231 \\
(147.699) \\
\end{array}$ & $\begin{array}{l}30.677 \\
(92.999)\end{array}$ & $\begin{array}{r}-36.172 \\
(42.821)\end{array}$ & $\begin{array}{r}17.729 \\
(43.804)\end{array}$ & 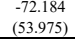 & $\begin{array}{l}23.100 \\
(44.503)\end{array}$ & $\begin{array}{l}-5.260 \\
(25.020)\end{array}$ & (10.585) & $\begin{array}{l}-2.251 \\
(9.744)\end{array}$ & $\begin{array}{l}1.258 \\
(53.856)\end{array}$ & $\begin{array}{l}-\begin{array}{l}-13.881 \\
(43.880)\end{array} \\
y\end{array}$ & $\begin{array}{r}-43.725 \\
(80.229)\end{array}$ & $\begin{array}{l}22.589 \\
(58.814)\end{array}$ & (34.350) & (110.191) & $\begin{array}{r}10.126 \\
(18.551)\end{array}$ & $\begin{array}{l}6.455 \\
(28.678)\end{array}$ & $\begin{array}{l}-51.1 .13 \\
(32.476)\end{array}$ & $\begin{array}{l}-0.991 \\
(5.481)\end{array}$ & (10.947) & $\begin{array}{l}4.089 \\
(5.660)\end{array}$ & $\begin{array}{l}-13.777 \\
(13.297)\end{array}$ & (26.439) & $\begin{array}{l}.612 \\
3766\end{array}$ \\
\hline & $\mathrm{Ye}_{\mathrm{C}}$ & Yes & Yes & Yes & tes & Yes & $\begin{array}{ll}\text { Yes } \\
\end{array}$ & Yes & Yes & 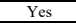 & Yes & Yes & Yes & $\begin{array}{l}\text { Yes } \\
\end{array}$ & Yes & Yes & Yes & $\begin{array}{l}\text { Yes } \\
\end{array}$ & $\begin{array}{l}\text { Yes } \\
\end{array}$ & es & Yes & Yes & $\begin{array}{l}\text { Yes } \\
\end{array}$ & $\begin{array}{l}\text { Yes } \\
\end{array}$ & Yes & Yes & & Yes & Yes & $\begin{array}{lll}\text { Yes } \\
\end{array}$ & Yes & & & \\
\hline & 0.102 & -0.061 & -0.116 & -0.006 & -0.132 & 0.055 & -0.140 & 0.027 & -0.115 & -0.052 & 0.209 & 0.216 & -0.095 & -0.039 & 0.030 & 0.171 & 0.111 & & R & 0.79 & 0.033 & 0.351 & & & & & & & 014 & 060 & & 896 & 230 & \\
\hline & 0.102 & -0.061 & -0.116 & -0.006 & -0.132 & 0.055 & -0.140 & 0.027 & -0.115 & -0.052 & 0.209 & 0.216 & -0.095 & -0.039 & 0.030 & 0.171 & 0.113 & & & 0.078 & & & & & & & & & & 0.060 & 0.262 & -0.086 & & 0.104 \\
\hline
\end{tabular}

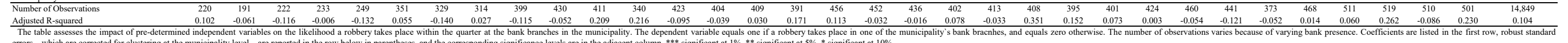


APPENDIX TABLEA

\begin{tabular}{|c|c|c|c|c|c|c|c|c|c|c|c|c|c|c|c|c|c|c|c|c|c|c|c|c|c|c|c|c|c|c|c|c|c|c|}
\hline Year & 2002 & 2003 & 2003 & 2003 & 2003 & 2004 & 2004 & 2004 & 2004 & 2005 & 2005 & 2005 & 2005 & 2006 & 2006 & 2006 & 2006 & 2007 & 2007 & 2007 & 2007 & 2008 & 2008 & 2008 & 2008 & 2009 & 2009 & 2009 & 2009 & 2010 & 2010 & 2010 & 2010 & 2002:IV-2010:IV \\
\hline arter & IV & 1 & 11 & III & IV & I & III & III & IV & 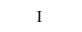 & II & III & IV & I & II & III & IV & I & II & III & IV & I & II & III & IV & $\mathrm{I}$ & II & III & IV & & II & III & IV & \\
\hline & -0.000 & $-0.001^{* * * *}$ & -0.000 & 0.000 & -0.000 & $0.000^{* *}$ & -0.001 & -0.000 & $-0.001^{* * *}$ & 0.000 & -0.000 & -0.002 & -0.001 & $-0.002^{* * * *}$ & -0.000 & -0.000 & -0.000 & $0.000^{* * *}$ & 0.000 & 0.000 & 0.000 & -0.000 & $-0.001^{*}$ & $-0.001^{* * *}$ & 0.000 & $-0.000^{*}$ & 0.000 & $-0.000^{* * *}$ & $-0.000^{* * *}$ & $11^{* *}$ & & $11^{* * * *}$ & 000 & $0^{* * * *}$ \\
\hline & $\left(\begin{array}{l}(0.000) \\
0.000\end{array}\right.$ & $\begin{array}{l}(0.000) \\
0.000\end{array}$ & $\begin{array}{l}(0.000) \\
0.000\end{array}$ & $\begin{array}{l}(0.000) \\
-0.000\end{array}$ & $\begin{array}{l}(0.001) \\
-0.000\end{array}$ & $\begin{array}{l}(0.000) \\
0.000\end{array}$ & $\begin{array}{l}(0.000) \\
-0.000\end{array}$ & $\left(\begin{array}{l}0.001) \\
0.000\end{array}\right.$ & $\begin{array}{l}(0.000) \\
0.000^{* * *}\end{array}$ & ${ }_{0.000 * *}^{(0.000)}$ & $\begin{array}{l}(0.000) \\
-0.000\end{array}$ & $\left(\begin{array}{l}0.001) \\
0.000\end{array}\right.$ & $\begin{array}{l}(0.001) \\
0.000^{*}\end{array}$ & $\begin{array}{l}(0.000) \\
-0.000\end{array}$ & $\begin{array}{l}(0.000) \\
-0.000\end{array}$ & $\left(\begin{array}{l}0.001) \\
-0.000\end{array}\right.$ & $\begin{array}{l}(0.000) \\
0.000\end{array}$. & $\begin{array}{l}(0.000) \\
-{ }_{-0.000 * * * *}\end{array}$ & $\begin{array}{l}*_{-0.000}^{(0.000)} \\
*\end{array}$ & $\begin{array}{l}(0.000) \\
-0.000 * * *\end{array}$ & $\begin{array}{l}(0.000) \\
-0.000 * *\end{array}$ & $\left(\begin{array}{c}0.000) \\
-0.000\end{array}\right.$ & $\begin{array}{l}(0.000) \\
0.0000^{* * *}\end{array}$ & $(0.001)$ & $(0.000)$ & $(0.000)$ & $(0.000)$ & $(0.000)$ & $(0.000)$ & $\begin{array}{l}(0.000) \\
0.000 * *\end{array}$ & $\begin{array}{l}(0.001) \\
0.00 * * *\end{array}$ & .0.000) & $(0.000)$ & 000) \\
\hline & $(0.000)$ & $(0.000)$ & $(0.000)$ & $(0.000)$ & $(0.000)$ & (0.000) & $(0.000)$ & $(0.000)$ & $\begin{array}{l}0.00000 \\
(0.000)\end{array}$ & 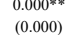 & $\begin{array}{l}-0.000 \\
(0.000)\end{array}$ & $\begin{array}{l}0.000 \\
(0.000)\end{array}$ & 00 ) & $\begin{array}{l}-0.000 \\
(0.000)\end{array}$ & $\begin{array}{l}-0.000 \\
(0.000)\end{array}$ & $\begin{array}{l}-0.0000 \\
(0.000)\end{array}$ & $\begin{array}{l}0.000 \\
(0.000)\end{array}$ & 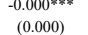 & 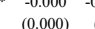 & $\begin{array}{l}-0.000000 \\
(0.000\end{array}$ & 0.000 & & 0.00000 & $\begin{array}{l}0.000 \\
(0.000\end{array}$ & $\begin{array}{l}-0.0000 \\
(0.000)\end{array}$ & 0000 & 0 & (0.000) & ono & (0.0000) & 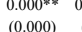 & $00)$ & 00 & \\
\hline & 0.047 & 0.068 & 0.016 & 0.002 & & & 0.006 & & & & (0.0000) & 0.009 & & & $0.074 *$ & $0.024^{*}$ & (10.000 & ) & & & & & & & & & & & & & & & & \\
\hline & & $(0.042)$ & & & & $(0.026)$ & & (0.023) & $(0.012)$ & 62) & 224) & & 18) & $(0.054)$ & & & & $(0.03$ & & & 287 & $(0.022)$ & $(0.023)$ & $(0.0$ & & & & & & & & & & \\
\hline & *** & -0.004 & -0.001 & 0.000 & $15^{* * * *}$ & $0.000^{* * *}$ & -0.000 & $-0.000^{*}$ & $-0.000 * *$ & $-0.000^{* *}$ & $-0.001 * * *$ & -0.000 & -0.000 & -0.002 & & -0.000 & -0.0 & -0.0 & $-0.6 \quad$ & -0.4 & .000" & $-0.001 *$ & $-0.000^{*}$ & -0.6 & -0.0 & -0.0 & 000 & -0.001 & & $-0.000^{*}$ & & & & \\
\hline & & $(0.003)$ & $(0.0 \quad$ & $(0.000)$ & $(0.001)$ & $(0.000)$ & $(0.000)$ & $(0.000)$ & $(0.000)$ & $(0.000)$ & $(0.000)$ & $(0.001)$ & $(0.000)$ & $(0.002)$ & & (0.) & $(0.00$ & (0.6 & $(0.00)$ & $(0.6 \mathrm{C}$ & & $(0.00$ & $(0.000)$ & & $(0.0$ & $(0.000)$ & & & & & & & & \\
\hline & & $-0.086^{* * *}$ & $0.081 * * *$ & -0.002 & 00 & $0.0 \mathrm{c}$ & $-0.1011^{* * * *}$ & 0.032 & -0.086 & $0.100^{0 * * * *}$ & 0.0 & -0.062 & -0.083 & 0006 & 006 & 139 & $97 * * * *$ & 0.052 & $0.213^{* * *}$ & $-0.8 \mathrm{C}$ & & $-0.097 * * x$ & -0.026 & $-0.10^{0 * *} \quad 0$ & $0.142^{* * *}$ & -0.074 & & 0.110 & 14 & & $-0.086^{*}$ & 653 & & 20 \\
\hline & $(0.039)$ & $(0.039)$ & $(0.031)$ & $(0.039)$ & $(0.032)$ & $(0.026)$ & $(0.030)$ & $(0.040)$ & $(0.055)$ & $(0.042)$ & $(0.053)$ & $(0.0$ & $(0.074)$ & 744) & & $(0.046)$ & & $(0.141)$ & $(0.079)$ & 0.6 & & $(0.029)$ & & $(0.048)$ & $(0.049)$ & & & & & & & & & \\
\hline & & -0.003 & & & & & 0.003 & & & & & & & & & & & ${ }^{-0.003}$ & & & & & & & & & & & & & & & & \\
\hline & $(0.012)$ & $(0.006)$ & $(0.003)$ & $(0.011)$ & $\begin{array}{l}(0.005) \\
0.03 *\end{array}$ & $(0.002)$ & $(0.005)$ & $(0.003)$ & $(0.003)$ & $(0.006)$ & $(0.004)$ & $\begin{array}{l}(0.009) \\
(0.02 * * * *\end{array}$ & $(0.012)$ & $(0.004)$ & $(0.004)$ & $(0.004)$ & $(0.005)$ & $\begin{array}{l}(0.005) \\
0.01 * *\end{array}$ & $(0.009)$ & $(0.0$ & 03) & $(0.002)$ & $(0.002)$ & $(0.6$ & $(0.4$ & 0.00 & 04) & $(0.003)$ & $(0.002)$ & $(0.004)$ & $(0.008)$ & & (0.005) & \\
\hline & & $(0.026$ & 06 & $\begin{array}{r}-0.0043 \\
-0.0043)\end{array}$ & & & & $\begin{array}{l}-0.002 \\
-0.007\end{array}$ & $\begin{array}{l}0.0211^{* *} \\
(0.010)\end{array}$ & $\begin{array}{r}-0.018 \\
-0.132\end{array}$ & $\begin{array}{r}-0.008 \\
-0.009\end{array}$ & $0.023^{0 * * *}$ & (0.006) & (0.008) & (0.012) & $\begin{array}{l}-.003 \\
-0.005)\end{array}$ & & 0.01 & & (0) & & 等 & $(0.025)$ & & (00 & 077 & 18) & & (9023) & & & & & 2 \\
\hline & & 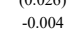 & & $\begin{array}{l}(0.013) \\
0.001\end{array}$ & 14) & & & (0.007) & $\begin{array}{c}-0.00090) \\
-0.009 * *\end{array}$ & - 0.0 .001$)$ & $\begin{array}{l}(0.009) \\
0.002\end{array}$ & & & (0.008) & & & & & & & & (0.011) & $\begin{array}{l}(0.023) \\
0.12 * *\end{array}$ & & & & & & & & & & & \\
\hline & & & & & & & & & & $(0.002)$ & & & & & & & & & $(0.6)$ & $(0.6)$ & & & $(0.05)$ & & & $(0.001)$ & 027 & & & & & & & \\
\hline & $\begin{array}{l}-0.05) \\
-1.194\end{array}$ & 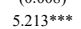 & $-2.8377^{* * * *}$ & 0.244 & & * & -1.472 & $\begin{array}{l}0.782 \\
-2.782\end{array}$ & 1.643) & $7.073^{* * * * *}$ & 12.003) & $88.824 * *$ & 1.644 & $-33.362^{*}$ & & - & $\begin{array}{l}0.0 .047) \\
-0.325\end{array}$ & -1712 & & & & & & 0.0 & 48 & & & (1) & & & & & & \\
\hline & ) & $(1$. & (1. & $(1.186)$ & $(1.9)$ & & $(0$. & $(2.255)$ & (1.500) & $(2.0$ & & 4) & $(2.491)$ & $(18$ & (2. & (0.s & $(0$. & & 8) & (5. & $(1.178)$ & & $(3.192)$ & $(1$. & $(0.883)$ & $(1$. & 5) & $(2.081)$ & ( & (1.1772) & $(3.315)$ & & 3) & \\
\hline & & 2063 & -0.513 & 0.095 & & 03 & & $-2.427 * *$ & 0.208 & $1.884^{* * * *}$ & & $-88.952^{*}$ & & $-35.158^{* * *}$ & -1.589 & $-4.385^{* * * *}$ & -0.363 & -1.012 & & & & 0.511 & -2.150 & 0.125 & -1.069 & -0.079 & $\begin{array}{l}-1.142 \quad 2 \\
-1\end{array}$ & $2.290^{* * * * 1} 1$ & & 0.400 & & & & \\
\hline & $(1.096)$ & (1.812) & $(0.654)$ & $(0.387)$ & $(0.804)$ & $(0.640)$ & & (1.148) & $(0.384)$ & $(0.581)$ & $(3.841)$ & $(47.118)$ & $(9.786)$ & (17.857) & $(2.527)$ & (1.458) & $(0.366)$ & (0.963) & $(3.023)$ & ) & 60) & $(0.761)$ & (2.187) & $(1.009)$ & $(0.658)$ & (0.008) & (0.961) & $(0.486)$ & ( & $(0.563)$ & 55) & 274) & & \\
\hline & & 0.000 & & 0.000 & & 0000 & $0.000^{* *}$ & & $0.000^{* * *}$ & & & & & & 00 & & & $0.000^{* * * *}$ & $0.000^{* * *}$ & & & $00^{*}$ & $0.000^{* * * *}$ & $0.000^{* * * *} 0$ & $0.000^{* * *}$ & $0.000^{* * *}$ & $10^{* *} 0$ & & & & & & & \\
\hline & $(0.000)$ & $(0.000)$ & $(0.000)$ & $(0.000)$ & $(0.000)$ & $(0.000)$ & $(0.000)$ & $(0.000)$ & $(0.000)$ & (0.000) & (0.000) & $(0.000)$ & $(0.000)$ & $(0.000)$ & $(0.000)$ & $(0.000)$ & $(0.000)$ & (0.000) & $(0.000)$ & $(0.000)$ & $(0.000)$ & $(0.000)$ & $(0.000)$ & $(0.000)$ & $(0.000)$ & $(0.000)$ & $(0.000)$ & $(0.000)$ & $(0.000)$ & $(0.000)$ & $(0.000)$ & (0.000) & $(0.000)$ & 0) \\
\hline & (8. & $(9.668)$ & $\begin{array}{l}35.183 * * * \\
(5.380)\end{array}$ & 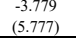 & $\begin{array}{l}2.988 \\
(9.727)\end{array}$ & 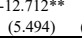 & $\begin{array}{l}6.291 \\
6.3611 \\
\end{array}$ & $\begin{array}{c}9.259 \\
(10.484)\end{array}$ & $\begin{array}{l}-10.03636- \\
(7.357)\end{array}$ & $\begin{array}{l}21.094 * 62 * * \\
(10.672)\end{array}$ & 80) & & $\begin{array}{l}0.2 .24 \\
2.870)\end{array}$ & 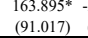 & $\begin{array}{c}-28.804 * * \\
(11.356)\end{array}$ & 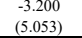 & 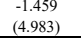 & $\begin{array}{l}2.600 \\
11.794)\end{array}$ & $\begin{array}{l}-81.2 \\
(26\end{array}$ & (29. & 674) & $\begin{aligned}-10.826 \\
(10.061)\end{aligned}$ & $\begin{array}{c}9.1 .178 \\
(15.200)\end{array}$ & $\begin{array}{l}-4.956 \\
(8.399) \\
\end{array}$ & 4.527 & $\begin{array}{l}-9.955 \\
(7.344)\end{array}$ & $\begin{array}{l}.761 \\
.900) \\
\end{array}$ & $(9.991)$ & $\begin{array}{l}16.047 .78 * * \\
(5.785)\end{array}$ & 357) & 358) & 82) & $\begin{array}{l}-38.8 .866^{* * * * *} \\
(11.64)\end{array}$ & \\
\hline & & & & & 24 & & & & & & & & & & & & & & & & & & & & & & & & & & & & & \\
\hline
\end{tabular}

$\overline{\text { Mean of Loan Amountimt-1 }}$

Variance of Loan Amount batr-

Mean of Loan Maturityom-1

Variance of Loan Maturity

Mean of Loan Interest Ratement

Variance of Loan Interest Ratetort-

Mean of Loan Percer

Variance of Loan Percentage Collateral

Mean or Loa $\begin{array}{lllllll}(8.403) & (9.668) & (5.380) & (5.777) & (9.727) & (5.24 & \\ 220 & 191 & 222 & 233 & 249 & \end{array}$

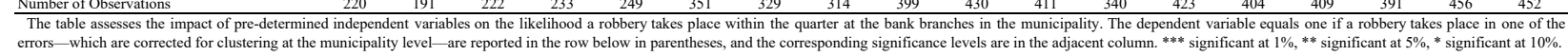




\begin{tabular}{|c|c|c|c|c|c|c|c|c|c|c|}
\hline \multirow{2}{*}{$\begin{array}{cc} & \text { Models } \\
& \text { Dependent Variables } \\
\text { Branch Robbed * After }\end{array}$} & "I & 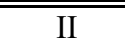 & 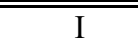 & 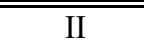 & 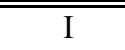 & II & 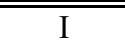 & II & 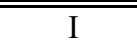 & III \\
\hline & \multicolumn{2}{|c|}{ Maturity } & \multicolumn{2}{|c|}{ Collateral } & \multicolumn{2}{|c|}{ Collateralization } & \multicolumn{2}{|c|}{ Interest Rate } & \multicolumn{2}{|c|}{ Loan Amount } \\
\hline Branch Robbed * After & $\begin{array}{c}0.95 \\
(4.06)\end{array}$ & $\begin{array}{c}0.48 \\
(4.28)\end{array}$ & $\begin{array}{c}-24.85^{* *} \\
(10.69)\end{array}$ & $\begin{array}{c}-24.97 * * \\
(11.13)\end{array}$ & $\begin{array}{c}-16.42 * \\
(9.03)\end{array}$ & $\begin{array}{c}-15.53 * \\
(9.11)\end{array}$ & $\begin{array}{c}2.243 \\
(2.704)\end{array}$ & $\begin{array}{c}2.307 \\
(2.734)\end{array}$ & $\begin{array}{c}51.75 \\
(311.69)\end{array}$ & $\begin{array}{c}131.32 \\
(318.05)\end{array}$ \\
\hline Branch Robbed * After * $\ln ($ Days After the Robbery) & $\begin{array}{c}0.16 \\
(1.213)\end{array}$ & $\begin{array}{c}0.28 \\
(1.26)\end{array}$ & $\begin{array}{l}6.73 * * \\
(3.17)\end{array}$ & $\begin{array}{l}6.75^{* *} \\
(3.28)\end{array}$ & $\begin{array}{l}4.41^{*} \\
(2.41)\end{array}$ & $\begin{array}{l}4.17^{*} \\
(2.42)\end{array}$ & $\begin{array}{c}-0.666 \\
(0.760)\end{array}$ & $\begin{array}{l}-0.696 \\
(0.774)\end{array}$ & $\begin{array}{l}-51.30 \\
(78.56)\end{array}$ & $\begin{array}{l}-72.54 \\
(80.83)\end{array}$ \\
\hline Branch Robbed * After * Firearm & $\begin{array}{c}2.36 \\
(4.27)\end{array}$ & $\begin{array}{c}2.75 \\
(4.49)\end{array}$ & $\begin{array}{c}28.63 * * \\
(11.56)\end{array}$ & $\begin{array}{c}28.72 * * \\
(11.87)\end{array}$ & $\begin{array}{c}20.61 * * \\
(9.48)\end{array}$ & $\begin{array}{c}19.86^{* *} \\
(9.48)\end{array}$ & $\begin{array}{l}-2.612 \\
(2.964)\end{array}$ & $\begin{array}{l}-2.664 \\
(2.980)\end{array}$ & $\begin{array}{c}3.09 \\
(329.23)\end{array}$ & $\begin{array}{c}-65.57 \\
(337.66)\end{array}$ \\
\hline Branch Robbed * After * $\ln ($ Days After the Robbery $) *$ Firearm & $\begin{array}{l}-0.88 \\
(1.27)\end{array}$ & $\begin{array}{l}-0.97 \\
(1.32)\end{array}$ & $\begin{array}{c}-7.65^{* *} \\
(3.41)\end{array}$ & $\begin{array}{c}-7.66^{* *} \\
(3.49)\end{array}$ & $\begin{array}{c}-5.67 * * \\
(2.53)\end{array}$ & $\begin{array}{c}-5.46^{* *} \\
(2.52)\end{array}$ & $\begin{array}{c}0.668 \\
(0.833)\end{array}$ & $\begin{array}{c}0.692 \\
(0.841)\end{array}$ & $\begin{array}{c}47.26 \\
(83.75)\end{array}$ & $\begin{array}{c}65.80 \\
(86.33)\end{array}$ \\
\hline Branch Robbed * After * Robbed Amount over Deposits & & $\begin{array}{c}0.02 * * \\
(0.01)\end{array}$ & & $\begin{array}{c}0.01 \\
(0.04)\end{array}$ & & $\begin{array}{l}-0.04 \\
(0.04)\end{array}$ & & $\begin{array}{l}-0.003 \\
(0.010)\end{array}$ & & $\begin{array}{c}-2.97 * * * \\
(0.98)\end{array}$ \\
\hline Branch Robbed * After * $\ln ($ Days After the Robbery $) *$ Robbed Amount over Deposits & & $\begin{array}{c}-0.01 * * \\
(0.00) \\
\end{array}$ & & $\begin{array}{l}-0.00 \\
(0.01) \\
\end{array}$ & & $\begin{array}{c}0.01 \\
(0.01) \\
\end{array}$ & & $\begin{array}{c}0.001 \\
(0.002) \\
\end{array}$ & & $\begin{array}{c}0.73 * * * \\
(0.26) \\
\end{array}$ \\
\hline Branch-Event Fixed Effects $(55,533)$ & Yes & Yes & Yes & Yes & Yes & Yes & Yes & Yes & Yes & Yes \\
\hline After-Event Fixed Effects (372) & Yes & Yes & Yes & Yes & Yes & Yes & Yes & Yes & Yes & Yes \\
\hline Industry Fixed Effects (17) & Yes & Yes & Yes & Yes & Yes & Yes & Yes & Yes & Yes & Yes \\
\hline Relationship and Firm Characteristics & Yes & Yes & Yes & Yes & Yes & Yes & Yes & Yes & Yes & Yes \\
\hline Adjusted R-squared & 0.11 & 0.11 & 0.10 & 0.10 & 0.08 & 0.07 & 0.43 & 0.43 & 0.11 & 0.11 \\
\hline
\end{tabular}

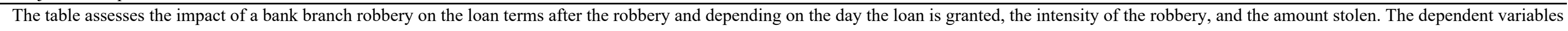

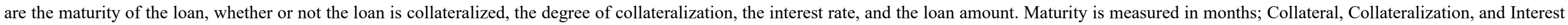

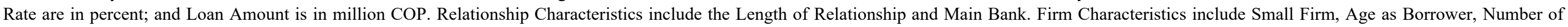

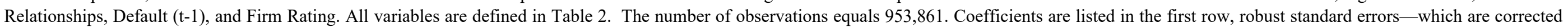

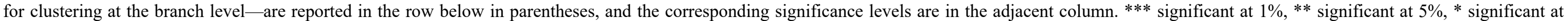
$10 \%$. 


\begin{tabular}{|c|c|c|c|c|c|c|c|c|c|c|}
\hline \multirow{2}{*}{$\begin{array}{rr} & \text { Models } \\
& \text { Dependent Variables } \\
\end{array}$} & $\mathrm{I}$ & II & I & II & \multirow{2}{*}{\multicolumn{2}{|c|}{$\begin{array}{cc}\text { I } & \text { II } \\
\text { Collateralization } \\
\end{array}$}} & $\mathrm{I}$ & II & $\mathrm{I}$ & II \\
\hline & \multicolumn{2}{|c|}{ Maturity } & \multicolumn{2}{|c|}{ Collateral } & & & \multicolumn{2}{|c|}{ Interest Rate } & \multicolumn{2}{|c|}{ Loan Amount } \\
\hline \multirow[t]{2}{*}{ Branch Robbed * After } & 4.379 & 4.012 & $-22.64 * * *$ & $-22.37 * * *$ & $-13.23 * * *$ & $-11.94 * * *$ & 2.329 & 2.416 & 59.25 & 149.46 \\
\hline & $(2.909)$ & $(2.934)$ & $(5.86)$ & $(6.12)$ & $(3.73)$ & $(3.73)$ & $(2.528)$ & $(2.539)$ & $(397.48)$ & $(405.55)$ \\
\hline \multirow[t]{2}{*}{ Branch Robbed * After * $\ln ($ Days After the Robbery) } & -0.830 & -0.742 & $5.69 * * *$ & $5.60 * * *$ & $3.15^{* *}$ & $2.83 * *$ & -0.630 & -0.663 & -16.40 & -39.95 \\
\hline & $(0.922)$ & $(0.926)$ & $(2.08)$ & $(2.12)$ & $(1.23)$ & $(1.19)$ & $(0.719)$ & $(0.729)$ & $(126.08)$ & $(129.91)$ \\
\hline \multirow[t]{2}{*}{ Branch Robbed $*$ After * Firearm } & -1.499 & -1.203 & $24.65 * * *$ & $24.41 * * *$ & $15.86^{* * *}$ & $14.77 * * *$ & -2.506 & -2.579 & -44.40 & -121.80 \\
\hline & $(2.962)$ & $(3.015)$ & $(6.41)$ & $(6.57)$ & $(4.11)$ & (4.09) & $(2.751)$ & $(2.750)$ & (421.17) & (430.61) \\
\hline \multirow[t]{2}{*}{ Branch Robbed $*$ After $* \ln ($ Days After the Robbery $) *$ Firearm } & 0.208 & 0.140 & $-6.26 * * *$ & $-6.19 * * *$ & $-4.10 * * *$ & $-3.84 * * *$ & 0.595 & 0.622 & 13.37 & 33.66 \\
\hline & $(0.936)$ & $(0.949)$ & $(2.22)$ & $(2.24)$ & $(1.27)$ & $(1.23)$ & $(0.782)$ & $(0.787)$ & $(129.52)$ & (133.53) \\
\hline \multirow[t]{2}{*}{ Branch Robbed * After * Robbed Amount over Deposits } & & $0.019 *$ & & -0.01 & & -0.06 & & -0.004 & & $-3.42 *$ \\
\hline & & $(0.010)$ & & $(0.05)$ & & $(0.04)$ & & $(0.010)$ & & $(1.76)$ \\
\hline \multirow[t]{2}{*}{ Branch Robbed * After * $\ln ($ Days After the Robbery $) *$ Robbed Amount over Deposits } & & $-0.005 * *$ & & 0.00 & & 0.01 & & 0.001 & & $0.87 * *$ \\
\hline & & $(0.002)$ & & $(0.01)$ & & $(0.01)$ & & $(0.002)$ & & $(0.43)$ \\
\hline Branch-Event Fixed Effects $(150,699)$ & Yes & Yes & Yes & Yes & Yes & Yes & Yes & Yes & Yes & Yes \\
\hline After-Event Fixed Effects (389) & Yes & Yes & Yes & Yes & Yes & Yes & Yes & Yes & Yes & Yes \\
\hline Industry Fixed Effects (17) & Yes & Yes & Yes & Yes & Yes & Yes & Yes & Yes & Yes & Yes \\
\hline Relationship and Firm Characteristics & Yes & Yes & Yes & Yes & Yes & Yes & Yes & Yes & Yes & Yes \\
\hline Loan Characteristics & Yes & Yes & Yes & Yes & Yes & Yes & Yes & Yes & Yes & Yes \\
\hline Adjusted R-squared & 0.15 & 0.15 & 0.16 & 0.16 & 0.11 & 0.11 & 0.45 & 0.45 & 0.14 & 0.14 \\
\hline
\end{tabular}

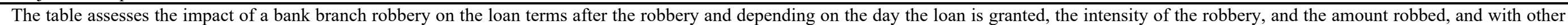

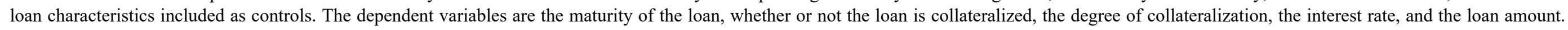

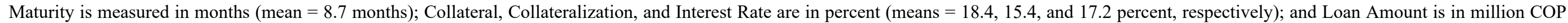

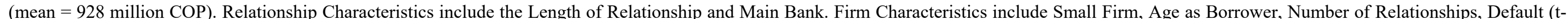

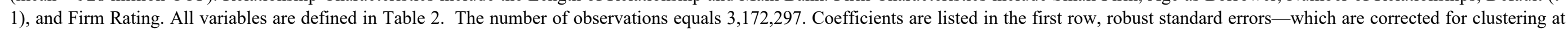

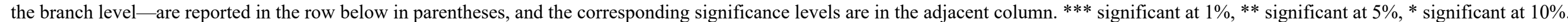


APPENDIX TABLE A.6.-CORRELATIONS BETWEEN OUTCOME VARIABLES

\begin{tabular}{l|ccccc}
\hline \hline & Maturity & Collateral & Collateralization & Loan Amount & Interest Rate \\
\hline Maturity & 1 & & & & \\
Collateral & $0.2241^{*}$ & 1 & & & \\
Collateralization & $0.1451^{*}$ & $0.6568^{*}$ & 1 & 1 & 1 \\
Loan Amount & $0.0216^{*}$ & $-0.0480^{*}$ & $-0.0456^{*}$ & $-0.2343^{*}$ & 1 \\
Interest Rate & $-0.1050^{*}$ & $-0.0791^{*}$ & $-0.0641^{*}$ & -0.00
\end{tabular}

The table reports the correlation coefficients between the outcome variables. The number of observations equals $3,172,297$. * Indicates significance at the 5\% level. 
APPENDIX TABLE A.7.-IMPACT ON LOAN TERMS AFTER BANK BRANCH ROBBERY, NOT INCLUDING BRANCH-EVENT FIXED EFFECTS

\begin{tabular}{|c|c|c|c|c|c|c|c|c|c|c|}
\hline \multirow{2}{*}{$\begin{array}{rr} & \text { Models } \\
& \text { Dependent Variables } \\
\end{array}$} & \multirow{2}{*}{\multicolumn{2}{|c|}{$\begin{array}{l}\text { I } \\
\text { Maturity } \\
\end{array}$}} & $\overline{\mathrm{I}}$ & $\overline{\mathrm{II}}$ & \multirow{2}{*}{\multicolumn{2}{|c|}{$\begin{array}{cc}\text { I } & \text { II } \\
\text { Collateralization } \\
\end{array}$}} & II & $\overline{\mathrm{II}}$ & II & $\overline{\mathrm{II}}$ \\
\hline & & & \multicolumn{2}{|c|}{ Collateral } & & & \multicolumn{2}{|c|}{ Interest Rate } & \multicolumn{2}{|c|}{ Loan Amount } \\
\hline Branch Robbed * After & $\begin{array}{l}-1.08 \\
(3.69)\end{array}$ & $\begin{array}{l}-1.65 \\
(3.86)\end{array}$ & $\begin{array}{c}-19.51^{*} \\
(10.28)\end{array}$ & $\begin{array}{c}-19.43^{*} \\
(10.62)\end{array}$ & $\begin{array}{c}-17.30^{* *} \\
(7.92)\end{array}$ & $\begin{array}{c}-15.20^{* *} \\
(7.29)\end{array}$ & $\begin{array}{c}3.921 \\
(3.323)\end{array}$ & $\begin{array}{c}3.826 \\
(3.303)\end{array}$ & $\begin{array}{l}-465.67 \\
(284.77)\end{array}$ & $\begin{array}{l}-289.74 \\
(314.95)\end{array}$ \\
\hline Branch Robbed * After * $\ln ($ Days After the Robbery) & $\begin{array}{l}-0.06 \\
(1.12)\end{array}$ & $\begin{array}{l}0.09 \\
(1.15)\end{array}$ & $\begin{array}{c}4.97 \\
(3.23)\end{array}$ & $\begin{array}{c}4.97 \\
(3.32)\end{array}$ & $\begin{array}{l}3.80 \\
(2.35)\end{array}$ & $\begin{array}{l}3.35 \\
(2.28)\end{array}$ & $\begin{array}{l}-0.961 \\
(0.789)\end{array}$ & $\begin{array}{l}-0.963 \\
(0.791)\end{array}$ & $\begin{array}{c}79.58 \\
(102.96)\end{array}$ & $\begin{array}{c}43.42 \\
(107.00)\end{array}$ \\
\hline Branch Robbed * After * Firearm & $\begin{array}{c}1.84 \\
(3.95)\end{array}$ & $\begin{array}{c}2.31 \\
(4.12)\end{array}$ & $\begin{array}{c}22.70 * * \\
(11.29)\end{array}$ & $\begin{array}{c}22.63 * * \\
(11.47)\end{array}$ & $\begin{array}{c}21.92 * * * \\
(8.38)\end{array}$ & $\begin{array}{c}20.13 * * * \\
(7.70)\end{array}$ & $\begin{array}{l}-4.748 \\
(3.481)\end{array}$ & $\begin{array}{l}-4.659 \\
(3.460)\end{array}$ & $\begin{array}{l}711.38 * * \\
(333.90)\end{array}$ & $\begin{array}{c}555.85 \\
(353.73)\end{array}$ \\
\hline Branch Robbed * After * $\ln ($ Days After the Robbery $) *$ Firearm & $\begin{array}{l}-0.53 \\
(1.16)\end{array}$ & $\begin{array}{l}-0.65 \\
(1.20)\end{array}$ & $\begin{array}{l}-5.90 * \\
(3.42)\end{array}$ & $\begin{array}{l}-5.90^{*} \\
(3.48)\end{array}$ & $\begin{array}{c}-4.96 * * \\
(2.47)\end{array}$ & $\begin{array}{c}-4.58^{*} \\
(2.39)\end{array}$ & $\begin{array}{c}0.972 \\
(0.871)\end{array}$ & $\begin{array}{c}0.971 \\
(0.871)\end{array}$ & $\begin{array}{c}-89.60 \\
(103.59)\end{array}$ & $\begin{array}{c}-57.78 \\
(107.95)\end{array}$ \\
\hline Branch Robbed * After * Robbed Amount over Deposits & & $\begin{array}{l}0.03 * * \\
(0.01)\end{array}$ & & $\begin{array}{l}-0.01 \\
(0.04)\end{array}$ & & $\begin{array}{c}-0.08 * * \\
(0.04)\end{array}$ & & $\begin{array}{c}0.002 \\
(0.010)\end{array}$ & & $\begin{array}{c}-5.44 * * * \\
(1.50)\end{array}$ \\
\hline Branch Robbed * After * $\ln ($ Days After the Robbery $) *$ Robbed Amount over Deposits & & $\begin{array}{c}-0.01 * * \\
(0.00)\end{array}$ & & $\begin{array}{c}0.00 \\
(0.01) \\
\end{array}$ & & $\begin{array}{l}0.02 * \\
(0.01) \\
\end{array}$ & & $\begin{array}{c}0.000 \\
(0.002) \\
\end{array}$ & & $\begin{array}{c}1.19 * * * \\
(0.31)\end{array}$ \\
\hline Branch-Event Fixed Effects $(150,699)$ & No & No & No & No & No & No & No & No & No & No \\
\hline After-Event Fixed Effects (389) & Yes & Yes & Yes & Yes & Yes & Yes & Yes & Yes & Yes & Yes \\
\hline Industry Fixed Effects (17) & Yes & Yes & Yes & Yes & Yes & Yes & Yes & Yes & Yes & Yes \\
\hline Relationship and Firm Characteristics & Yes & Yes & Yes & Yes & Yes & Yes & Yes & Yes & Yes & Yes \\
\hline Adjusted R-squared & 0.10 & 0.11 & 0.10 & 0.10 & 0.08 & 0.08 & 0.41 & 0.41 & 0.11 & 0.11 \\
\hline
\end{tabular}

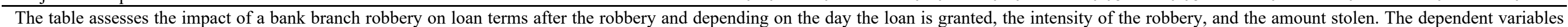

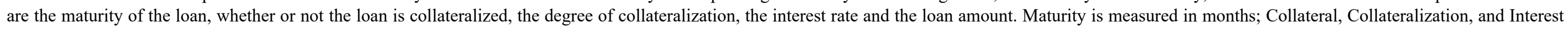

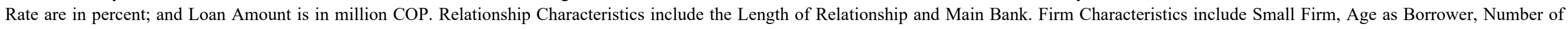

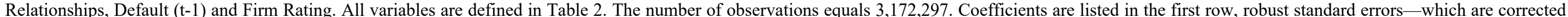

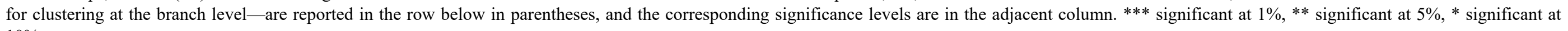
$10 \%$. 


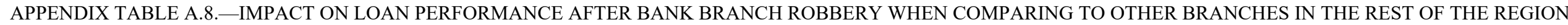

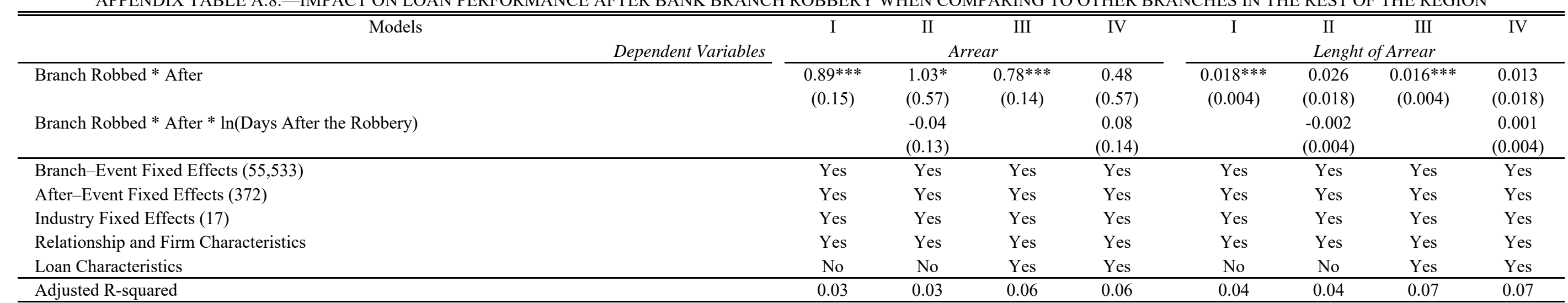

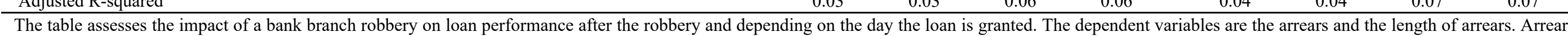

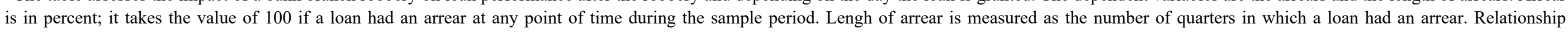

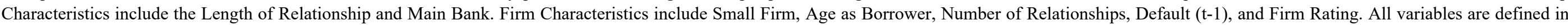

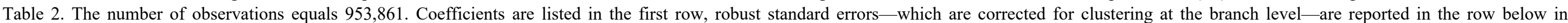
parentheses, and the corresponding significance levels are in the adjacent column. *** significant at $1 \%$, ** significant at $5 \%$, * significant at $10 \%$. 
APPENDIX TABLE A.9.-IMPACT ON LOAN TERMS AFTER PLACEBO BANK BRANCH ROBBERY ONE YEAR PRIOR TO THE ACTUAL ROBBERY

\begin{tabular}{|c|c|c|c|c|c|c|c|c|c|c|}
\hline \multirow{2}{*}{$\begin{array}{rr} & \text { Models } \\
& \text { Dependent Variables } \\
\end{array}$} & \multirow{2}{*}{\multicolumn{2}{|c|}{ Maturity }} & $\begin{array}{ll}\mathrm{I} \\
\end{array}$ & II & $\overline{\mathrm{I}}$ & II & $\overline{\mathrm{I}}$ & II & $\overline{\mathrm{I}}$ & II \\
\hline & & & \multicolumn{2}{|c|}{ Collateral } & \multicolumn{2}{|c|}{ Collateralization } & \multicolumn{2}{|c|}{ Interest Rate } & \multicolumn{2}{|c|}{ Loan Amount } \\
\hline Branch Robbed * After & $\begin{array}{l}-1.60 \\
(4.99)\end{array}$ & $\begin{array}{l}-2.43 \\
(5.17)\end{array}$ & $\begin{array}{c}-6.23 \\
(18.88)\end{array}$ & $\begin{array}{c}-5.97 \\
(19.07)\end{array}$ & $\begin{array}{c}0.79 \\
(11.83)\end{array}$ & $\begin{array}{c}1.25 \\
(12.40)\end{array}$ & $\begin{array}{l}-3.781 \\
(3.155)\end{array}$ & $\begin{array}{l}-3.657 \\
(3.192)\end{array}$ & $\begin{array}{c}365.15 \\
(321.32)\end{array}$ & $\begin{array}{c}388.59 \\
(322.05)\end{array}$ \\
\hline Branch Robbed * After * $\ln ($ Days After the Robbery) & $\begin{array}{c}0.76 \\
(1.36)\end{array}$ & $\begin{array}{c}0.94 \\
(1.40)\end{array}$ & $\begin{array}{c}1.45 \\
(5.18)\end{array}$ & $\begin{array}{c}1.44 \\
(5.23)\end{array}$ & $\begin{array}{l}-0.30 \\
(3.22)\end{array}$ & $\begin{array}{l}-0.34 \\
(3.36)\end{array}$ & $\begin{array}{c}1.074 \\
(0.859)\end{array}$ & $\begin{array}{c}1.069 \\
(0.864)\end{array}$ & $\begin{array}{c}-117.29 \\
(108.91)\end{array}$ & $\begin{array}{c}-122.48 \\
(108.81)\end{array}$ \\
\hline Branch Robbed * After * Firearm & $\begin{array}{c}2.07 \\
(5.44)\end{array}$ & $\begin{array}{c}2.84 \\
(5.61)\end{array}$ & $\begin{array}{c}6.00 \\
(20.42)\end{array}$ & $\begin{array}{c}5.74 \\
(20.58)\end{array}$ & $\begin{array}{c}1.26 \\
(12.65)\end{array}$ & $\begin{array}{c}0.82 \\
(13.16)\end{array}$ & $\begin{array}{c}3.916 \\
(3.339)\end{array}$ & $\begin{array}{c}3.795 \\
(3.371)\end{array}$ & $\begin{array}{c}-386.58 \\
(330.82)\end{array}$ & $\begin{array}{l}-408.23 \\
(332.38)\end{array}$ \\
\hline Branch Robbed * After * $\ln ($ Days After the Robbery $) *$ Firearm & $\begin{array}{l}-0.63 \\
(1.47)\end{array}$ & $\begin{array}{c}-0.80 \\
(1.51)\end{array}$ & $\begin{array}{l}-1.61 \\
(5.53)\end{array}$ & $\begin{array}{l}-1.60 \\
(5.56)\end{array}$ & $\begin{array}{l}-0.56 \\
(3.42)\end{array}$ & $\begin{array}{l}-0.51 \\
(3.54)\end{array}$ & $\begin{array}{l}-1.170 \\
(0.900)\end{array}$ & $\begin{array}{l}-1.161 \\
(0.904)\end{array}$ & $\begin{array}{c}125.70 \\
(112.62)\end{array}$ & $\begin{array}{c}130.46 \\
(112.66)\end{array}$ \\
\hline Branch Robbed * After * Robbed Amount over Deposits & & $\begin{array}{c}0.03 \\
(0.04)\end{array}$ & & $\begin{array}{l}-0.00 \\
(0.04)\end{array}$ & & $\begin{array}{l}-0.01 \\
(0.04)\end{array}$ & & $\begin{array}{c}-0.002 \\
(0.009)\end{array}$ & & $\begin{array}{l}-0.85 \\
(1.33)\end{array}$ \\
\hline Branch Robbed * After * $\ln ($ Days After the Robbery) $*$ Robbed Amount over Deposits & & $\begin{array}{c}-0.01 \\
(0.01) \\
\end{array}$ & & $\begin{array}{l}-0.00 \\
(0.01) \\
\end{array}$ & & $\begin{array}{l}-0.00 \\
(0.01) \\
\end{array}$ & & $\begin{array}{c}-0.001 \\
(0.002) \\
\end{array}$ & & $\begin{array}{c}0.20 \\
(0.31) \\
\end{array}$ \\
\hline Branch-Event Fixed Effects $(105,188)$ & Yes & Yes & Yes & Yes & Yes & Yes & Yes & Yes & Yes & Yes \\
\hline After-Event Fixed Effects (300) & Yes & Yes & Yes & Yes & Yes & Yes & Yes & Yes & Yes & Yes \\
\hline Industry Fixed Effects (17) & Yes & Yes & Yes & Yes & Yes & Yes & Yes & Yes & Yes & Yes \\
\hline Relationship and Firm Characteristics & Yes & Yes & Yes & Yes & Yes & Yes & Yes & Yes & Yes & Yes \\
\hline Loan Characteristics & Yes & Yes & Yes & Yes & Yes & Yes & Yes & Yes & Yes & Yes \\
\hline Adjusted R-squared & 0.11 & 0.11 & 0.10 & 0.10 & 0.10 & 0.10 & 0.38 & 0.38 & 0.12 & 0.12 \\
\hline
\end{tabular}

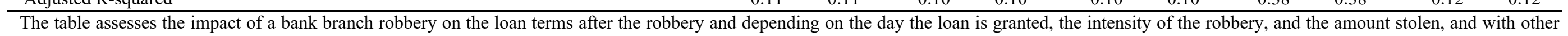

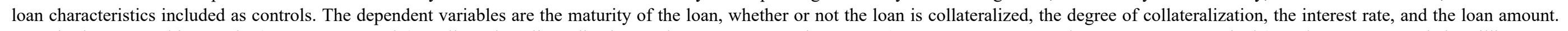

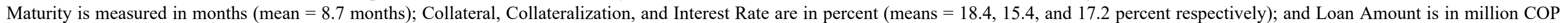

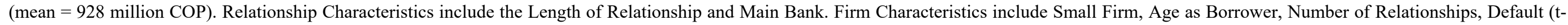

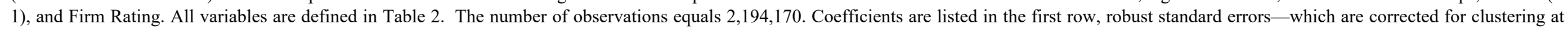

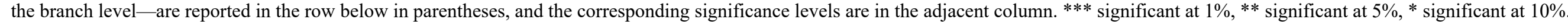


APPENDIX TABLE A.10.-IMPACT ON LOAN TERMS AFTER BANK BRANCH ROBBERY IN BRANCHES THAT WERE ROBBED ONLY ONCE

\begin{tabular}{|c|c|c|c|c|c|c|c|c|c|c|}
\hline \multirow{2}{*}{$\begin{array}{r}\text { Models } \\
\text { Dependent Variables } \\
\end{array}$} & 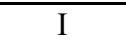 & 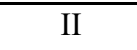 & 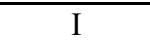 & $\overline{\mathrm{II}}$ & 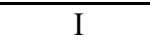 & III & 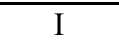 & $\overline{\mathrm{II}}$ & 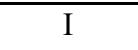 & II \\
\hline & \multicolumn{2}{|c|}{ Maturity } & \multicolumn{2}{|c|}{ Collateral } & \multicolumn{2}{|c|}{ Collateralization } & \multicolumn{2}{|c|}{ Interest Rate } & \multicolumn{2}{|c|}{ Loan Amount } \\
\hline \multirow[t]{2}{*}{ Branch Robbed * After } & 1.767 & 1.342 & $-23.53 * * *$ & $-23.62 * * *$ & $-14.15^{* * *}$ & $-13.24 * * *$ & 2.717 & 2.783 & -38.65 & 25.88 \\
\hline & $(3.687)$ & $(3.830)$ & $(8.40)$ & $(8.89)$ & $(4.59)$ & $(4.61)$ & $(2.674)$ & $(2.692)$ & $(215.39)$ & $(213.84)$ \\
\hline \multirow[t]{2}{*}{ Branch Robbed * After * $\ln ($ Days After the Robbery) } & -0.147 & -0.044 & $6.09 * *$ & $6.10 * *$ & $3.55 * *$ & $3.33^{*}$ & -0.740 & -0.767 & 13.63 & -2.54 \\
\hline & $(1.165)$ & $(1.200)$ & $(2.87)$ & $(2.97)$ & $(1.79)$ & $(1.79)$ & $(0.754)$ & $(0.765)$ & $(71.85)$ & $(72.92)$ \\
\hline \multirow[t]{2}{*}{ Branch Robbed $*$ After $*$ Firearm } & 1.061 & 1.380 & $26.92 * * *$ & $26.97 * * *$ & $17.67 * * *$ & $16.94 * * *$ & -3.068 & -3.119 & -108.41 & -161.57 \\
\hline & $(3.951)$ & $(4.080)$ & $(9.91)$ & $(10.14)$ & $(5.98)$ & $(5.84)$ & $(2.977)$ & $(2.968)$ & $(228.95)$ & $(231.53)$ \\
\hline \multirow[t]{2}{*}{ Branch Robbed * After * $\ln ($ Days After the Robbery $) *$ Firearm } & -0.452 & -0.526 & $-6.92 * *$ & $-6.92 * *$ & $-4.62 * *$ & $-4.45 * *$ & 0.757 & 0.777 & 32.75 & 46.26 \\
\hline & $(1.245)$ & $(1.277)$ & $(3.23)$ & $(3.28)$ & $(2.05)$ & $(2.02)$ & $(0.835)$ & $(0.838)$ & $(70.96)$ & $(72.78)$ \\
\hline \multirow[t]{2}{*}{ Branch Robbed * After * Robbed Amount over Deposits } & & $0.022 *$ & & 0.01 & & -0.04 & & -0.003 & & $-2.32 * *$ \\
\hline & & $(0.012)$ & & $(0.05)$ & & $(0.04)$ & & $(0.010)$ & & $(0.93)$ \\
\hline \multirow[t]{2}{*}{ Branch Robbed * After * $\ln ($ Days After the Robbery) $*$ Robbed Amount over Deposits } & & $-0.006^{* *}$ & & -0.00 & & 0.01 & & 0.001 & & $0.55 * *$ \\
\hline & & $(0.003)$ & & $(0.01)$ & & $(0.01)$ & & $(0.002)$ & & $(0.25)$ \\
\hline Branch-Event Fixed Effects $(123,645)$ & Yes & Yes & Yes & Yes & Yes & Yes & Yes & Yes & Yes & Yes \\
\hline After-Event Fixed Effects (318) & Yes & Yes & Yes & Yes & Yes & Yes & Yes & Yes & Yes & Yes \\
\hline Industry Fixed Effects (17) & Yes & Yes & Yes & Yes & Yes & Yes & Yes & Yes & Yes & Yes \\
\hline Relationship and Firm Characteristics & Yes & Yes & Yes & Yes & Yes & Yes & Yes & Yes & Yes & Yes \\
\hline Adjusted R-squared & 0.11 & 0.11 & 0.10 & 0.10 & 0.08 & 0.08 & 0.413 & 0.413 & 0.11 & 0.11 \\
\hline
\end{tabular}

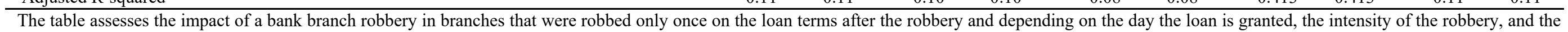

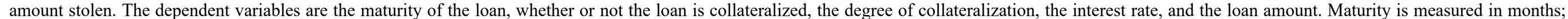

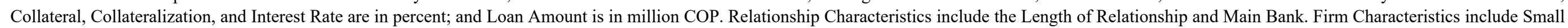

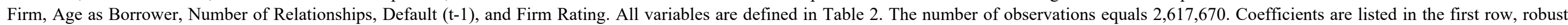

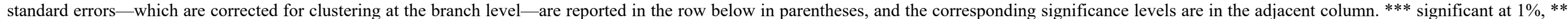
significant at $5 \%, *$ significant at $10 \%$. 


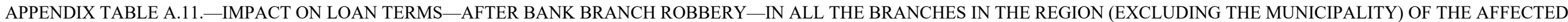
BANK

\begin{tabular}{|c|c|c|c|c|c|c|c|c|c|c|}
\hline \multirow{2}{*}{$\begin{array}{lr} & \text { Models } \\
& \text { Dependent Variables } \\
\text { Branch Robbed * After } & \end{array}$} & \multirow{2}{*}{\multicolumn{2}{|c|}{$\begin{array}{l}\text { I II } \\
\text { Maturity }\end{array}$}} & \multirow{2}{*}{\multicolumn{2}{|c|}{$\begin{array}{l}\text { I II } \\
\text { Collateral }\end{array}$}} & \multirow{2}{*}{\multicolumn{2}{|c|}{$\begin{array}{cc}\text { I } & \text { II } \\
\text { Collateralization }\end{array}$}} & \multirow{2}{*}{\multicolumn{2}{|c|}{$\begin{array}{cr}\text { I } & \text { II } \\
\text { Interest Rate }\end{array}$}} & \multirow{2}{*}{\multicolumn{2}{|c|}{$\begin{array}{cc}\text { I } & \text { II } \\
\text { Loan } & \text { Amount }\end{array}$}} \\
\hline & & & & & & & & & & \\
\hline Branch Robbed * After & $\begin{array}{c}1.663 \\
(1.830)\end{array}$ & $\begin{array}{c}2.630 \\
(2.969)\end{array}$ & $\begin{array}{l}-0.42 \\
(2.66)\end{array}$ & $\begin{array}{c}1.22 \\
(3.75)\end{array}$ & $\begin{array}{l}-0.33 \\
(3.61)\end{array}$ & $\begin{array}{l}-3.99 \\
(6.76)\end{array}$ & $\begin{array}{c}0.414 \\
(0.863)\end{array}$ & $\begin{array}{c}1.461 \\
(1.540)\end{array}$ & $\begin{array}{l}-222.51 \\
(247.38)\end{array}$ & $\begin{array}{l}-530.76^{*} \\
(289.08)\end{array}$ \\
\hline Branch Robbed * After * $\ln ($ Days After the Robbery) & $\begin{array}{l}-0.593 \\
(0.493)\end{array}$ & $\begin{array}{l}-1.146 \\
(0.786)\end{array}$ & $\begin{array}{l}-0.47 \\
(0.86)\end{array}$ & $\begin{array}{l}-1.29 \\
(1.07)\end{array}$ & $\begin{array}{c}0.49 \\
(1.06)\end{array}$ & $\begin{array}{l}1.47 \\
(2.15)\end{array}$ & $\begin{array}{c}0.218 \\
(0.271)\end{array}$ & $\begin{array}{l}-0.333 \\
(0.420)\end{array}$ & $\begin{array}{c}34.92 \\
(60.09)\end{array}$ & $\begin{array}{l}102.26 \\
(73.04)\end{array}$ \\
\hline Branch Robbed * After * Firearm & $\begin{array}{l}-0.703 \\
(2.349)\end{array}$ & $\begin{array}{l}-1.732 \\
(3.465)\end{array}$ & $\begin{array}{c}1.97 \\
(3.94)\end{array}$ & $\begin{array}{l}-0.27 \\
(4.72)\end{array}$ & $\begin{array}{c}3.41 \\
(3.98)\end{array}$ & $\begin{array}{c}5.74 \\
(7.23)\end{array}$ & $\begin{array}{l}-0.387 \\
(0.756)\end{array}$ & $\begin{array}{l}-1.401 \\
(1.567)\end{array}$ & $\begin{array}{c}162.69 \\
(236.67)\end{array}$ & $\begin{array}{l}479.93 * \\
(264.49)\end{array}$ \\
\hline Branch Robbed * After * $\ln ($ Days After the Robbery $) *$ Firearm & $\begin{array}{c}0.426 \\
(0.665)\end{array}$ & $\begin{array}{c}0.996 \\
(0.928)\end{array}$ & $\begin{array}{c}0.09 \\
(1.22)\end{array}$ & $\begin{array}{c}1.11 \\
(1.32)\end{array}$ & $\begin{array}{l}-1.37 \\
(1.18)\end{array}$ & $\begin{array}{l}-2.00 \\
(2.29)\end{array}$ & $\begin{array}{l}-0.298 \\
(0.211)\end{array}$ & $\begin{array}{c}0.238 \\
(0.417)\end{array}$ & $\begin{array}{l}-20.41 \\
(56.69)\end{array}$ & $\begin{array}{l}-89.77 \\
(65.94)\end{array}$ \\
\hline Branch Robbed * After * Robbed Amount over Deposits & & $\begin{array}{c}0.002 \\
(0.002)\end{array}$ & & $\begin{array}{c}0.02 * * * \\
(0.01)\end{array}$ & & $\begin{array}{c}0.05^{* * *} \\
(0.01)\end{array}$ & & $\begin{array}{l}-0.001 \\
(0.001)\end{array}$ & & $\begin{array}{c}-0.36^{* *} \\
(0.17)\end{array}$ \\
\hline Branch Robbed * After * $\ln ($ Days After the Robbery) $*$ Robbed Amount over Deposits & & $\begin{array}{l}-0.001 \\
(0.000) \\
\end{array}$ & & $\begin{array}{c}-0.01 * * * \\
(0.00) \\
\end{array}$ & & $\begin{array}{c}-0.01 * * * \\
(0.00) \\
\end{array}$ & & $\begin{array}{l}0.001 * * \\
(0.000) \\
\end{array}$ & & $\begin{array}{l}0.08 * * \\
(0.04) \\
\end{array}$ \\
\hline Branch-Event Fixed Effects $(137,456)$ & Yes & Yes & Yes & Yes & Yes & Yes & Yes & Yes & Yes & Yes \\
\hline After-Event Fixed Effects (369) & Yes & Yes & Yes & Yes & Yes & Yes & Yes & Yes & Yes & Yes \\
\hline Industry Fixed Effects (17) & Yes & Yes & Yes & Yes & Yes & Yes & Yes & Yes & Yes & Yes \\
\hline Relationship and Firm Characteristics & Yes & Yes & Yes & Yes & Yes & Yes & Yes & Yes & Yes & Yes \\
\hline Adjusted R-squared & 0.10 & 0.10 & 0.10 & 0.10 & 0.08 & 0.08 & 0.42 & 0.42 & 0.11 & 0.11 \\
\hline
\end{tabular}

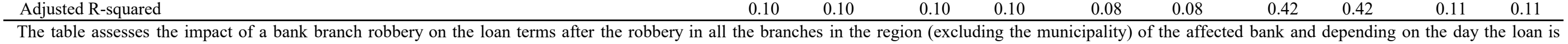

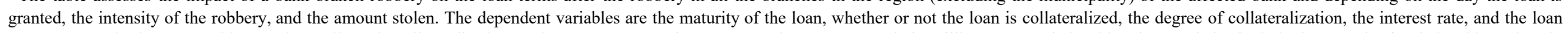

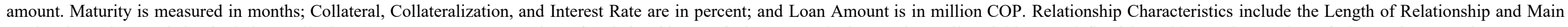

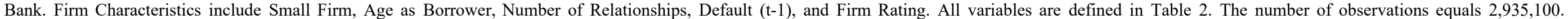

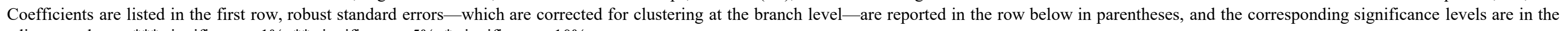
adjacent column. $* * *$ significant at $1 \%, * *$ significant at $5 \%, *$ significant at $10 \%$. 


\begin{tabular}{|c|c|c|c|c|c|c|c|c|c|c|}
\hline \multirow{2}{*}{$\begin{array}{lr} & \begin{array}{c}\text { Models } \\
\end{array} \\
\text { Branch Robbed * After } & \text { Dependent Variables } \\
\end{array}$} & II & II & \multirow{2}{*}{\multicolumn{2}{|c|}{$\begin{array}{l}\text { I } \quad \text { II } \\
\text { Collateral } \\
\end{array}$}} & \multirow{2}{*}{\multicolumn{2}{|c|}{$\begin{array}{cc}\text { I } & \text { II } \\
\text { Collateralization } \\
\end{array}$}} & \multirow{2}{*}{\multicolumn{2}{|c|}{$\begin{array}{cr}\mathrm{I} & \mathrm{II} \\
\text { Interest } & \text { Rate } \\
\end{array}$}} & \multirow{2}{*}{\multicolumn{2}{|c|}{$\begin{array}{cc}\mathrm{I} & \mathrm{II} \\
\text { Loan } & \text { Amount } \\
\end{array}$}} \\
\hline & \multicolumn{2}{|c|}{ Maturity } & & & & & & & & \\
\hline Branch Robbed * After & $\begin{array}{l}4.817^{*} \\
(2.823)\end{array}$ & $\begin{array}{l}4.943^{*} \\
(2.775)\end{array}$ & $\begin{array}{c}-15.11^{* * * *} \\
(1.91)\end{array}$ & $\begin{array}{c}-19.86^{* * *} \\
(5.57)\end{array}$ & $\begin{array}{c}-17.85^{* * * *} \\
(1.28)\end{array}$ & $\begin{array}{c}-22.63 * * * \\
(5.99)\end{array}$ & $\begin{array}{c}-0.146 \\
(3.961)\end{array}$ & $\begin{array}{c}0.378 \\
(3.933)\end{array}$ & $\begin{array}{c}171.80 \\
(191.49)\end{array}$ & $\begin{array}{c}385.22^{* *} \\
(191.09)\end{array}$ \\
\hline Branch Robbed * After * $\ln ($ Days After the Robbery) & $\begin{array}{l}-1.049 \\
(0.829)\end{array}$ & $\begin{array}{l}-1.060 \\
(0.808)\end{array}$ & $\begin{array}{c}3.33^{* * *} \\
(0.65)\end{array}$ & $\begin{array}{c}4.47 * * * \\
(1.43)\end{array}$ & $\begin{array}{c}3.90 * * * \\
(0.33)\end{array}$ & $\begin{array}{c}4.98 * * * \\
(1.41)\end{array}$ & $\begin{array}{c}0.016 \\
(1.048)\end{array}$ & $\begin{array}{l}-0.177 \\
(1.034)\end{array}$ & $\begin{array}{c}0.59 \\
(95.10)\end{array}$ & $\begin{array}{l}-44.84 \\
(87.32)\end{array}$ \\
\hline Branch Robbed * After * Firearm & $\begin{array}{l}-1.388 \\
(2.839)\end{array}$ & $\begin{array}{l}-1.496 \\
(2.756)\end{array}$ & $\begin{array}{c}18.16^{* * *} \\
(2.85)\end{array}$ & $\begin{array}{c}22.21 * * * \\
(5.05)\end{array}$ & $\begin{array}{c}22.45^{* * *} \\
(3.13)\end{array}$ & $\begin{array}{c}26.54 * * * \\
(5.24)\end{array}$ & $\begin{array}{c}0.659 \\
(3.975)\end{array}$ & $\begin{array}{c}0.211 \\
(3.920)\end{array}$ & $\begin{array}{l}-160.50 \\
(167.12)\end{array}$ & $\begin{array}{c}-342.74 * * \\
(155.82)\end{array}$ \\
\hline Branch Robbed $*$ After $* \ln ($ Days After the Robbery) $*$ Firearm & $\begin{array}{c}0.404 \\
(0.861)\end{array}$ & $\begin{array}{c}0.414 \\
(0.836)\end{array}$ & $\begin{array}{c}-3.97 * * * \\
(0.82)\end{array}$ & $\begin{array}{c}-4.94 * * * \\
(1.30)\end{array}$ & $\begin{array}{c}-5.17 * * * \\
(0.77)\end{array}$ & $\begin{array}{c}-6.09 * * * \\
(1.25)\end{array}$ & $\begin{array}{l}-0.259 \\
(1.049)\end{array}$ & $\begin{array}{l}-0.095 \\
(1.027)\end{array}$ & $\begin{array}{c}8.48 \\
(84.69)\end{array}$ & $\begin{array}{c}47.46 \\
(76.04)\end{array}$ \\
\hline Branch Robbed * After * Robbed Amount over Deposits & & $\begin{array}{l}-0.018 \\
(0.123)\end{array}$ & & $\begin{array}{c}0.69 \\
(0.71)\end{array}$ & & $\begin{array}{c}0.70 \\
(0.88)\end{array}$ & & $\begin{array}{l}-0.078 \\
(0.085)\end{array}$ & & $\begin{array}{l}-30.99 \\
(20.15)\end{array}$ \\
\hline Branch Robbed * After * $\ln ($ Days After the Robbery) $*$ Robbed Amount over Deposits & & $\begin{array}{c}0.002 \\
(0.030)\end{array}$ & & $\begin{array}{l}-0.17 \\
(0.16)\end{array}$ & & $\begin{array}{l}-0.16 \\
(0.19)\end{array}$ & & $\begin{array}{c}0.028 \\
(0.023)\end{array}$ & & $\begin{array}{c}6.65 \\
(4.60)\end{array}$ \\
\hline Branch-Event Fixed Effects $(46,284)$ & Yes & Yes & Yes & Yes & Yes & Yes & Yes & Yes & Yes & Yes \\
\hline After-Event Fixed Effects (125) & Yes & Yes & Yes & Yes & Yes & Yes & Yes & Yes & Yes & Yes \\
\hline Industry Fixed Effects (17) & Yes & Yes & Yes & Yes & Yes & Yes & Yes & Yes & Yes & Yes \\
\hline Relationship and Firm Characteristics & Yes & Yes & Yes & Yes & Yes & Yes & Yes & Yes & Yes & Yes \\
\hline Adjusted R-squared & 0.11 & 0.11 & 0.10 & 0.10 & 0.08 & 0.08 & 0.41 & 0.41 & 0.11 & 0.11 \\
\hline
\end{tabular}

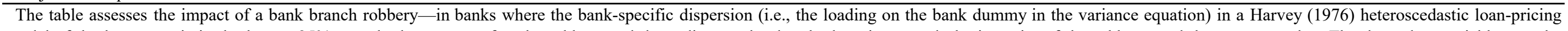

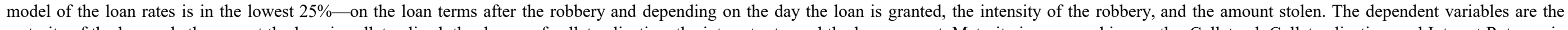

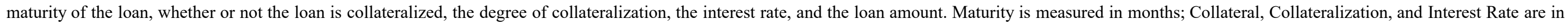

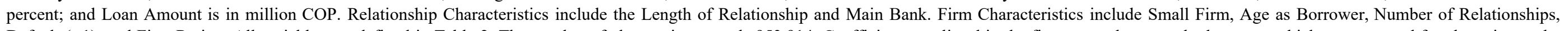

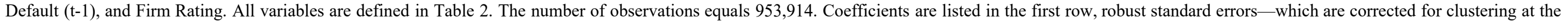
branch level—are reported in the row below in parentheses, and the corresponding significance levels are in the adjacent column. $* * *$ significant at $1 \%$, ** significant at $5 \%, *$ significant at $10 \%$. 